\title{
De positie en aansluiting op de arbeidsmarkt van schoolverlaters van het MBO in Midden-Limburg
}

Citation for published version (APA):

van de Loo, P. J. E., \& de Grip, A. (1989). De positie en aansluiting op de arbeidsmarkt van schoolverlaters van het MBO in Midden-Limburg. Researchcentrum voor Onderwijs en Arbeidsmarkt, Faculteit der Economische Wetenschappen. ROA Reports No. 5

https://doi.org/10.26481/umarep.1989005

Document status and date:

Published: 01/01/1989

DOI:

10.26481/umarep.1989005

Document Version:

Publisher's PDF, also known as Version of record

\section{Please check the document version of this publication:}

- A submitted manuscript is the version of the article upon submission and before peer-review. There can be important differences between the submitted version and the official published version of record.

People interested in the research are advised to contact the author for the final version of the publication, or visit the DOI to the publisher's website.

- The final author version and the galley proof are versions of the publication after peer review.

- The final published version features the final layout of the paper including the volume, issue and page numbers.

Link to publication

\footnotetext{
General rights rights.

- You may freely distribute the URL identifying the publication in the public portal. please follow below link for the End User Agreement:

www.umlib.nl/taverne-license

Take down policy

If you believe that this document breaches copyright please contact us at:

repository@maastrichtuniversity.nl

providing details and we will investigate your claim.
}

Copyright and moral rights for the publications made accessible in the public portal are retained by the authors and/or other copyright owners and it is a condition of accessing publications that users recognise and abide by the legal requirements associated with these

- Users may download and print one copy of any publication from the public portal for the purpose of private study or research.

- You may not further distribute the material or use it for any profit-making activity or commercial gain

If the publication is distributed under the terms of Article $25 \mathrm{fa}$ of the Dutch Copyright Act, indicated by the "Taverne" license above, 
DE POSITIE EN AANSLUITING OP DE ARBEIDSMARKT VAN SCHOOLVERLATERS VAN HET MBO EN KORT MBO IN MIDDEN-LIMBURG ROA-R-1989/5

Maastricht, september 1989

P.J.E. van de Loo, A. de Grip

RESEARCHCENTRUM VOOR

ONDERWIJS EN ARBEIDSMARKT

Faculteit der Economische Wetenschappen Rijksuniversiteit Limburg 


\section{VERKLARING DER TEKENS EN BEGRIPPEN}

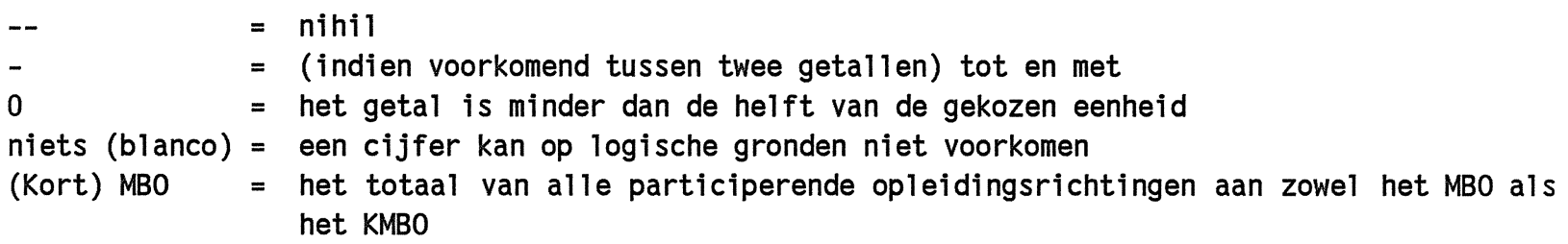

Naast dit rapport omvat het onderzoek een gelijknamige samenvatting, een tabellenboek en een bijlagenboek. Zowel het tabellen-, als het bijlagenboek zijn ter inzage aanwezig bij het ROA en bij het COA Midden-Limburg. De samenvatting kan bij het COA Midden-Limburg worden besteld:

Researchcentrum voor Onderwijs en Arbeidsmarkt (ROA) Faculteit der Economische Wetenschappen Rijksuniversiteit Limburg Postbus 616

6200 MD Maastricht

Telefoon: (043) 888120
Contactcentrum Onderwijs Arbeid (COA) Stichting COA-Limburg Regio Midden-Limburg Postbus 1226 6040 KE Roermond

Telefoon: (04750) 17733

Door het afronden van de percentages op gehele getallen kan het voorkomen, dat het totaal (100\%) in een tabel niet geheel overeenstemt met de som der afzonderlijke percentages. 

VERANTWOORDING

Bladzijde

LEESWIJZER

SAMENVATTING i i

1. HET ONDERZOEKSPLAN 1

1.1. De aansluitingsproblematiek tussen onderwijs en arbeidsmarkt 1

1.2. Onderzoeksopzet 5

1.2.1. Aanleiding en doelstelling onderzoek 5

1.2.2. Afbakening en operationalisatie van probleemstelling en onderzoekspopulatie $\quad 7$

1.2.3. De schoolverlatersenquête 11

1.2.4. De rapportage 14

1.3. Technische evaluatie van de schoolverlatersenquête 15

1.3.1. Respons en representativiteit 15

1.3.2. Beoordeling van de vragenlijst 18

2. EEN ALGEMENE KARAKTERISTIEK VAN DE SCHOOLVERLATERS 21

2.1. Enkele achtergrondkenmerken van de schoolverlaters 21

2.2. De keuze van de opleidingsrichting aan het (Kort) MBO 26

3. DE ARBEIDSMARKTPOSITIE VAN DE SCHOOLVERLATERS 32

3.1. Toetreding tot de arbeidsmarkt 32

3.1.1. Activiteiten na het (Kort) MBO 32

3.1.2. Huidige economische situatie 36

3.2. Schoolverlaters zonder betaald werk 38

3.2.1. Vervolgopleidingen 39

3.2.2. Werkloosheid 41

3.2.3. Dienstplicht 42

3.2.4. Werkervaring 43

3.3. Schoolverlaters met betaald werk 43

3.3.1. Arbeidsvoorwaarden en arbeidsmarktflexibiliteit 44

3.3.2. Beroepen 49

3.3.3. Bedrijfssectoren 54

3.3.4. Regionale spreiding 58

3.3.5. Geografische mobiliteit 60

3.3.6. Inkomen 62

3.3.7. Functie-aspecten 64 
4. DE KWALITATIEVE AANSLUITING TUSSEN OPLEIDING EN ARBEIDSMARKT

4.1. De aansluiting tussen opleiding en functie in het algemeen 67

4.2. Beoordeling van de gevolgde (Kort) MBO-opleiding 68

4.2.1. Theoretisch-technische kennis 68

4.2.2. Taalvaardigheden 75

4.2.3. Praktische vaardigheden 77

4.2.4. De stage 80

4.3. Aanvullende opleidingen en begeleiding 83

4.3.1. Behoefte aan extra kennis en vaardigheden 83

4.3.2. Aanvullende cursussen 86

4.3.3. Begeleiding door werkgever 90

5. CONCLUSIES 93

5.1. Inleiding 93

5.2. De arbeidsmarktpositie van de schoolverlaters 94

5.2.1. Toetreding tot de arbeidsmarkt 94

5.2.2. Verschillen tussen de schooltypen 95

5.2.3. Verschillen tussen de examenjaren 1987 en 198898

5.3. De kwalitatieve aansluiting tussen opleiding en arbeidsmarkt 99

5.3.1. Aansluiting tussen opleiding en functie in het algemeen 99

5.3.2. Beoordeling van de (Kort) MBO-opleiding 99

5.3.3. Aanvullende opleidingen en begeleiding 101

5.4. Arbeidsmarktfactoren 101

5.5. Beleidsimplicaties 103

5.5.1. Voorstellen voor aanpassing van de (Kort) MBO-opleiding 103

5.5.2. Mogelijkheden voor werkgevers bij het verbeteren van de aansluiting naar de arbeidsmarkt 105

$\begin{array}{ll}\text { 5.6. Besluit } & 107\end{array}$

$\begin{array}{ll}\text { LITERATUUR } & 109\end{array}$

OVERZICHT VAN TABELLEN 110

OVERZICHT VAN FIGUREN 112

BIJLAGEN

Bijlage 1. Samenstelling van de begeleidingscommissie 113

Bijlage 2. Vragenlijst en begeleidende brief (versie MTS-1988) 114 
VERANTWOORDING

Uit de resultaten van de Enquête Regionale Bedrijfsontwikkeling (ERBO 1985) komt naar voren, dat de werkgevers problemen ondervinden bij het aantrekken van personeel voor productie-technische en in- en verkoopfuncties. Dit betreft met name de functies waarvoor een MBO-opleiding wordt gevraagd. Bovendien verwachten de werkgevers in de toekomst nog meer knelpunten bij het vervullen van vacatures.

Het $\mathrm{COA}^{1}$ Midden-Limburg acht het zinvol deze problematiek nader te analyseren door middel van een enquête onder de schoolverlaters van het (Kort) $\mathrm{MBO}^{2}$ in Midden-Limburg. Hiervoor verleent het COA Midden-Limburg aan het ROA ${ }^{3}$ de opdracht een dergelijke enquête op te zetten, in het kader van een stageonderzoek. Het onderzoek is uitgevoerd door P. van de Loo (stagiair) onder begeleiding van dr. A. de Grip en prof. dr. J.A.M. Heijke.

In de afgelopen maanden zijn veel mensen betrokken geraakt bij deze enquête. Met de steun en de adviezen van al deze personen is het gelukt in een kort tijdsbestek een uitgebreide vragenlijst op te stellen, ruim achthonderd schoolverlaters van het (Kort) MBO te benaderen en de vele resultaten in dit rapport weer te geven.

In de eerste plaats een woord van dank aan de leden van de begeleidingscommissie 4 voor het met de onderzoekers meedenken aan het maken van een solide werkplan, een geschikte vragenlijst en een bruikbaar rapport. Voor de prettige coördinatie tussen de leden van deze begeleidingscommissie, de participerende scholen en het ROA, verdient J. Notenboom alle lof.

1. $C O A=$ Contactcentrum Onderwijs Arbeid. Het centrum is een samenwerkingsverband tussen de betrokkenen bij onderwijs en arbeid. De activiteiten vinden provinciaal en regionaal plaats. De sleutelbegrippen zijn: voorlichting, advisering, coördinatie en realisatie van projecten met een brugfunctie tussen onderwijs en arbeid. Het COA Midden-Limburg is gevestigd in Roermond.

2. Met (Kort) MBO wordt in dit rapport telkens het totaal van alle participerende opleidingsrichtingen aan zowel het MBO als het Kort MBO bedoeld.

3. $R O A=$ Researchcentrum voor Onderwijs en Arbeidsmarkt, verbonden aan de Faculteit der Economische Wetenschappen, Rijksuniversiteit Limburg te Maastricht.

4. Een overzicht van de leden van deze begeleidingscommissie is te vinden in bijlage 1. 
Ook voor het personeel van de administratie- en reproductie-afdelingen van de meewerkende scholen een dankwoord voor het beschikbaar stellen van (anonieme) leerlinggegevens en voor de keurige verzorging van de reproductie en de verzending van de vragenlijsten.

Dr. J.D.P. Kasper van de sectie marketing van de Economische Faculteit is verdienstelijk geweest door zijn nuttige adviezen bij het opstellen van de vragenlijsten, evenals drs. R.J.P. Dekker door de hulp bij het verwerken van de gegevens. Vervolgens een woord van dank aan de medewerkers van het handelsregister van de Kamer van Koophandel Midden-Limburg voor hun medewerking bij het verzamelen van openbare informatie over de bedrijven, waarin de schoolverlaters momenteel werkzaam zijn en aan de medewerkers van het Arbeidsbureau Roermond voor het verschaffen van enkele gedetailleerde regionale werkloosheidscijfers.

De resultaten ${ }^{5}$ van deze schoolverlatersenquête kunnen het COA Midden-Limburg hopelijk ondersteunen bij haar activiteiten, die de regionale aansluitingsproblemen tussen het genoten onderwijs en de dagelijkse beroepspraktijk beogen te verminderen. Daarnaast biedt dit rapport eveneens nuttige informatie voor degenen die, al dan niet beroepshalve, geïnteresseerd zijn in het traject (Kort) MBO - arbeidsmarkt in het algemeen en het beleid daaromtrent in het bijzonder.

P.J.E. van de Loo

A. de Grip

Maastricht, september 1989

5. De (globale) resultaten van deze schoolverlatersenquête zijn ook terug te vinden in de gelijknamige samenvatting van het onderhavige rapport. Deze samenvatting kan bij het COA Midden-Limburg worden besteld. 


\section{LEESWIJZER}

De indeling van dit rapport is als volgt. In hoofdstuk 1 wordt ingegaan op het plan dat ten grondslag heeft gelegen aan dit onderzoek. Allereerst wordt een beeld geschetst van de aansluitingsproblematiek tussen het onderwijs en de arbeidsmarkt en de moeilijk vervulbare vacatures die zich als gevolg hiervan voordoen. Vervolgens wordt de onderzoeksopzet behandeld, waarin de probleemstelling en de onderzoekspopulatie worden beschreven, evenals de wijze waarop de schoolverlatersenquête is uitgevoerd en de resultaten zijn verzameld, verwerkt en geanalyseerd. Tenslotte wordt de enquête technisch geëvalueerd aan de hand van de responspercentages, de representativiteit van de respondenten en enkele opmerkingen over de vragenlijst zelf.

De hoofdstukken 2, 3 en 4 bevatten de empirische resultaten van de schoolverlatersenquête. Een algemene karakteristiek van de schoolverlaters wordt in hoofdstuk 2 gegeven. Hier komen enkele achtergrondkenmerken van de schoolverlaters aan bod, evenals de factoren die een rol hebben gespeeld bij de keuze van de opleidingsrichting aan het MBO en het Kort MBO.

Hoofdstuk 3 gaat in op de arbeidsmarktpositie van de schoolverlaters. Eerst wordt een overzicht gegeven van de (eventuele) toetreding tot de arbeidsmarkt. Na vervolgens eerst te zijn ingegaan op degenen die geen betaald werk hebben, wordt de positie van de (betaald-) werkenden op de arbeidsmarkt uitgebreid belicht.

In hoofdstuk 4 wordt het oordeel van de schoolverlaters over de kwalitatieve aansluiting tussen de opleiding en de arbeidsmarkt besproken. Allereerst wordt een algemeen oordeel over de aansluiting tussen de opleiding en de huidige functie geveld. Vervolgens worden verscheidene inhoudelijke aspecten van de gevolgde (Kort) MBO-opleiding beoordeeld. Tenslotte geven de schoolverlaters aan óf en op welke wijze zij de kennis en vaardigheden van hun opleiding aanvullen (door het volgen van cursussen e.d.). De tabellen, waarnaar in deze drie hoofdstukken veelvuldig wordt verwezen, zijn terug te vinden in het tabellenboek.

Tenslotte worden in hoofdstuk 5 een aantal inhoudelijke en beleidsmatige conclusies geformuleerd. Het hoofdstuk wordt besloten met enkele ideeën voor een follow-up van deze schoolverlatersenquête. 

SAMENVATTING

Het Onderzoeksplan

Bij de presentatie door de Kamer van Koophandel Midden-Limburg van de resultaten van de ERBO-enquête (1985) bleek dat bepaalde vacatures moeilijk vervulbaar waren en dat de bedrijven ook in de toekomst vacatureproblemen verwachtten. Naar de mening van de ondervraagde werkgevers betreffen de knelpunten bij het vervullen van vacatures met name productie-technische en in- en verkoopfuncties, waarbij MBO als opleidingsniveau is vereist. Naar aanleiding van deze resultaten achtte het COA Midden-Limburg het zinvol deze problematiek nader te analyseren, op basis van een enquête onder de schoolverlaters van de MBO-sectoren. Op grond van de gesignaleerde vacatureknelpunten is besloten alle gediplomeerde schoolverlaters uit de examenjaren 1987 en 1988 van de voltijdse opleidingen van het MEAO (m.u.v. secretariaatsrichting), het MMO-C (inclusief de groothandelsrichting), de MTS en het KMBO-Metaaltechnieken in Midden-Limburg (i.c. Roermond/Heythuysen) voor dit onderzoek te benaderen ( $=$ de onderzoekspopulatie). In dit onderzoek heeft onderstaande probleemstelling, die uit twee deelvragen is opgebouwd, als leidraad gefungeerd:

- welke verschillen bestaan er tussen de betreffende schoolverlaters in hun arbeidsmarktpositie?;

- welke verschillen bestaan er tussen de betreffende schoolverlaters met betrekking tot de aansluiting van de door hen gevolgde opleiding op hun huidige (start) functie?

Begin 1989 heeft het ROA, in opdracht van het COA Midden-Limburg, deze enquête onder de betreffende ruim 800 schoolverlaters gehouden. De vragenlijst is door $76 \%$ van de benaderde schoolverlaters ingevuld teruggestuurd, variërend van $64 \%$ voor het $K M B O$, via $70 \%$ voor het MMO tot $79 \%$ voor zowel het MEAO als de MTS. Uit het vergelijkend onderzoek tussen de respons en de nonrespons blijkt dat de respondenten overigens representatief zijn.

Een algemene karakteristiek van de schoolverlaters

Door de aanzienlijke oververtegenwoordiging van de MTS neemt het aantal vrouwen in de totale respons slechts $11 \%$ in. Bijna de helft van de MBO-ers heeft MAVO als vooropleiding, bijna tweederde van de KMBO-ers heeft voorheen een LBO-diploma behaald. Bovendien is het HAVO met $41 \%$ een belangrijke leverancier aan het MEAO. 
De schoolverlaters van het KMBO zijn over het algemeen het jongste, van de MTS het oudste.

De belangrijkste motieven voor het kiezen van de opleidingrichting waren "het graag in deze richting werken", "de vakken van de richting spraken aan" en "de grote kansen op werk". Het één na laatste motief was belangrijker voor de oud-leerlingen van het MEAO en MMO, het laatste meer voor degenen die het KMBO en de MTS hebben gekozen. Op de vraag of de kans op werk invloed heeft gehad op de keuze van de opleidingsrichting geeft ruim de helft een ontkennend antwoord.

Er blijkt een duidelijke samenhang te bestaan tussen de opleiding en het beroep van de ouders van de schoolverlaters met de door de schoolverlaters gekozen opleidingsrichting aan het (Kort) MBO. Zo hebben de vaders van MEAOers en MMO-ers vaker een algemeen voortgezette opleiding gehad en hebben daarentegen de vaders van de MTS-ers en KMBO-ers veelvuldiger lager beroepsonderwijs genoten. Tenslotte hebben de vaders van de MBO-ers over het algemeen langer regulier onderwijs gevolgd dan de vaders van de KMBO-ers.

\section{De toetreding tot de arbeidsmarkt}

Bijna de helft van de schoolverlaters heeft een betaalde baan, ruim een derde deel volgt dagonderwijs, terwijl $16 \%$ de dienstplicht vervult. Slechts enkele schoolverlaters blijken werkloos te zijn; $2 \%$ tot $6 \%$. Er blijken niet alleen grote verschillen te bestaan tussen de vier onderzochte schooltypen, maar ook tussen de examenjaren 1987 en 1988. Zo zijn de KMBO-ers vaker toegetreden tot de arbeidsmarkt, dan de oud-leerlingen van het MBO. Juist bij het MEAO en het MMO valt er tussen de twee examenjaren een belangrijke verschuiving waar te nemen; een toename van de doorstroming naar vervolgonderwijs, tegenover een dalende toetreding tot de arbeidsmarkt.

In het algemeen kiezen oudere, evenals vrouwelijke schoolverlaters, schoolverlaters met LBO als vooropleiding, schoolverlaters die aan het MBO hebben gedoubleerd en schoolverlaters waarvan de ouders een lagere opleiding hebben genoten vaker voor betaald werk. Daarentegen kiezen jongere, evenals mannelijke schoolverlaters, schoolverlaters met een HAVO-vooropleiding, schoolverlaters die niet hebben gedoubleerd aan het MBO en schoolverlaters waarvan de ouders een hogere opleiding hebben, vaker voor een vervolgopleiding. 
Schoolverlaters zonder betaald werk

Van degenen die nu dagonderwijs volgen zit momenteel $86 \%$ van de MEAO-ers en $58 \%$ van de MMO-ers op de HEAO en van de MTS-ers $83 \%$ op de HTS. Bijna de helft van de weinige KMBO-ers die verder zijn gaan leren doet opnieuw een opleiding aan het KMBO, de andere helft volgt onderwijs aan het MBO. Het belangrijkste motief voor het verder leren is de verwachting dat "de opleiding meer loopbaanmogelijkheden biedt". Ook werklozen en dienstplichtigen zijn bezig met verdere scholing. Van de werklozen heeft ruim de helft (en van de dienstplichtigen ruim éénderde) na het verlaten van het (Kort) MBO een cursus gevolgd. Van de dienstplichtige MBO-ers wil circa de helft na diensttijd direct gaan werken. Van de dienstplichtige KMBO-ers wil $43 \%$ werken in combinatie met een (avond)studie.

\section{Schoolverlaters met betaald werk}

Driekwart van de werkenden heeft een vaste aanstelling; $21 \%$ werkt op tijdelijke basis en $4 \%$ heeft een leer-/werkcontract (KMBO: $17 \%$ ). De schoolverlaters uit het examenjaar 1988 hebben vaker tijdelijk werk, dan de schoolverlaters uit 1987 (33\% versus $13 \%)$. Dit duidt enerzijds op een, na verloop van enige tijd, doorstromen naar vaste betrekkingen, anderzijds op een verslechtering van de arbeidsmarktpositie. Het overgrote deel werkt full-time; ruim $86 \%$ heeft namelijk een werkweek van 36 t/m 40 uur.

Ongeveer $85 \%$ van de werkzame MEAO-ers en circa $60 \%$ van de MM0-ers vervult een functie die past bij de richting van hun opleiding. Daarentegen is het niveau van de werkzaamheden dikwijls nogal laag. Circa $85 \%$ van de werkende KMBO-ers doet werk dat aansluit bij hun opleiding. Ook van de MTS-ers heeft circa 95\% een baan die bij hun opleiding past. De werkenden uit 1987 hebben vaker werk met een hoger functieniveau (zie opmerking bij tijdelijk werk).

Wanneer we kijken naar de bedrijfssectoren waarin de schoolverlaters terecht komen, zien we dat bijna de helft van de werkende MEAO-ers in de zakelijke dienstverlening werkt, tegenover een kwart in de industriële sector. Daarentegen werkt de helft van de werkzame MMO-ers in handelsbedrijven, $20 \%$ in de zakelijke dienstverlening en eveneens $20 \%$ in de industrie. Van de werkende MTS-ers heeft de helft een baan in de industrie, van de KMBO-ers zelfs $93 \%$. Daarnaast werkt $20 \%$ van de MTS-ers in de bouw en $10 \%$ bij ingenieurs- of architectenbureaus. 
Terwijl bijna de helft van de werkenden van het MEAO, het MMO en in iets mindere mate van het KMBO in het kleinbedrijf werkzaam zijn, werkt van de MTS-ers slechts $19 \%$ in het kleinbedrijf en $39 \%$ in het grootbedrijf.

Veel werk wordt dichtbij huis gevonden. Bijna de helft van alle werkenden is werkzaam in de subregio Roermond, maar van de MMO-ers werkt slechts $28 \%$ in deze regio. In Midden-Limburg (de regio's Roermond en Weert samen) werkt $83 \%$ van de werkende MEAO-ers, $56 \%$ van de MMO-ers, $59 \%$ van de MTS-ers en $51 \%$ van de KMBO-ers. De bereidheid tot geografische mobiliteit is bovendien beperkt. Alhoewel driekwart van de schoolverlaters die momenteel in Midden-Limburg werken bereid is een functie buiten deze regio te aanvaarden, zou ruim de helft hiervan alleen een baan in Noord- of Zuid-Limburg accepteren. Er blijkt overigens geen principieel verschil in de bereidheid tot geografische mobiliteit tussen de werkende en werkloze schoolverlaters.

Het modale netto inkomen per maand van de werkende schoolverlaters ligt tussen de duizend- en vijftienhonderd gulden; $38 \%$ verdient een dergelijk inkomen. KMBO-ers verdienen het minst; gemiddeld 1.215 gulden netto per maand, MTS-ers het meest; gemiddeld 1.625 gulden netto per maand. Werkende MEAO-ers en MMO-ers verdienen respectievelijk 1.390 en 1.354 gulden netto per maand. Deze inkomensverschillen zijn overigens deels te verklaren uit leeftijdsverschillen.

De arbeidsmarkt kan op een aantal punten flexibel worden genoemd, wanneer we kijken naar het toenemende aantal functies dat een tijdelijke aanstelling betreft, de vele wijzen waarop schoolverlaters werk zoeken (en vinden!) en het feit dat de schoolverlaters uit het examenjaar 1988, na het (Kort) MBO, niet bij minder werkgevers hebben gewerkt. Bovendien werkt ruim $10 \%$ van de schoolverlaters in een onregelmatige dienst en werkt tweederde van de werkenden geregeld over; van de MMO-ers zelfs $89 \%$.

De werkende schoolverlaters vinden "het zelfstandig kunnen werken" het belangrijkste kenmerk van hun functie, gevolgd door "het goed met mensen kunnen omgaan". De technisch geschoolden noemen daarnaast (uiteraard) vaak "het hebben van technisch inzicht".

De kwalitatieve aansluiting tussen opleiding en arbeidsmarkt

Ruim tweederde van de werkenden is van mening dat de huidige werkzaamheden aansluiten bij hun opleiding. De aansluiting tussen opleiding en werk is het 
beste bij de MEAO-ers; $75 \%$ spreekt van een goede aansluiting. Van de MTS-ers en $\mathrm{KMBO}$-ers vindt respectievelijk $71 \%$ en $66 \%$ dat de huidige functie aansluit bij hun opleiding. Daarentegen blijkt de aansluiting tussen opleiding en werk bij de MMO-ers weinig bevredigend te zijn; slechts $39 \%$ onder hen is tevreden over de aansluiting. De aansluiting blijkt overigens minder goed te zijn bij de werkende schoolverlaters uit 1988: $62 \%$ is tevreden over de aansluiting, tegenover $74 \%$ van de groep werkenden uit 1987 . Het is niet te zeggen of de minder adequate aansluiting bij de schoolverlaters uit 1988 het gevolg is van het feit dat deze groep zich minder lang op de arbeidsmarkt begeeft of dat hier sprake is van een tendens in de richting van een structureel verslechterde aansluiting tussen opleiding en werk.

De theoretisch-technische kennis en de taalvaardigheden worden over het algemeen beter beoordeeld dan de praktische vaardigheden. Vooral de schoolverlaters met een korte stageduur vinden dat de stage uitgebreid moet worden, op voorwaarde dat de stage inhoudelijk aansluit bij de opleiding. Bijna de helft van de werkenden heeft behoefte aan kennis en/of vaardigheden, die niet tijdens hun opleiding aan bod zijn gekomen. De werkende schoolverlaters noemen met name schoolspecifieke vakkennis en vaardigheden, computerkunde en sociale vaardigheden. Ruim de helft van de werkende schoolverlaters volgt een aanvullende cursus. MEAO-ers het meest: $62 \%$, tegenover $58 \%$ van de MMO-ers, $52 \%$ van de MTS-ers. KMBO-ers doen beduidend minder aan verdere scholing; slechts $39 \%$ onder hen volgt momenteel een aanvullende cursus.

Ruim driekwart van de schoolverlaters is bij aanvang van de huidige functie ingewerkt door collega's. Van de werkende MEAO-ers zelfs $89 \%$, van de MMO-ers slechts $67 \%$. Ongeveer een vijfde deel is daarentegen zonder enige hulp aan de huidige functie begonnen, waarbij de percentages uiteenlopen van $10 \%$ voor het MEAO tot $28 \%$ voor het MMO.

Conclusies $^{6}$

De verschillen tussen de schooltypen, met name wat betreft de arbeidsmarktpositie, kunnen voor een belangrijk deel worden verklaard door de verschillen tussen vraag en aanbod van bepaalde groepen schoolverlaters.

6. De beleidsimplicaties, die uit deze conclusies voortvloeien, zijn terug te vinden in hoofdstuk 5, paragraaf 5. Enerzijds betreffen deze beleidsimplicaties voorstellen voor aanpassing van de (Kort) MBO-opleiding, anderzijds mogelijkheden voor werkgevers om de aansluiting te verbeteren. 
Ook de meningsvorming onder werkgevers ten aanzien van een bepaalde opleiding speelt een belangrijke rol bij de arbeidsmarktperspectieven van de schoolverlaters van de desbetreffende opleiding. Zo blijken MEAO-ers, doordat zij, al dan niet terecht, hoger worden ingeschat door de werkgevers, MMO-ers te verdringen in de beroepsdomeinen waarop het MMO zich richt. Op grond van bijvoorbeeld de verschillen in beroep tussen MTS-ers en KMBO-ersMetaaltechnieken kan men concluderen dat werkgevers KMBO-ers met een opleiding in de Metaaltechnieken beschouwen als LTS-ers i.p.v. MTS-ers.

$\mathrm{Er}$ is geconstateerd dat de werkenden uit het examenjaar 1987 een betere arbeidsmarktpositie hebben dan de werkenden uit 1988. De oorzaak hiervan kan zijn dat schoolverlaters pas na enige tijd doorstromen naar hoger gekwalificeerde banen met betere arbeidsvoorwaarden. Daarentegen is het ook goed mogelijk dat de markt verzadigd is voor de beroepssectoren waarvoor deze schoolverlaters worden opgeleid. $\mathrm{Er}$ is dan sprake van onderbenutting. Uit de enquête is gebleken, dat de schoolverlaters uit 1988 sneller van werkgever hebben gewisseld. Dit duidt op een toenemend zoekgedrag op de arbeidsmarkt en mogelijk ook op verdringingsprocessen. Tenslotte zou het proces van interne arbeidsmarkten, waarbij men binnen een bedrijf doorstroomt naar een hogere functie, eventueel aangevuld met een bedrijfsopleiding, van toepassing kunnen zijn, met name op de MTS-ers.

Opvallend is ook de toename van het aantal schoolverlaters dat na de MBOopleiding nog verder doorleert. Dit proces heeft als gevolg dat veel gediplomeerde MBO-ers niet direct beschikbaar komen voor de arbeidsmarkt, waardoor de knelpuntenproblematiek rondom het vervullen van vacatures, waarvoor MBO-diploma's worden gevraagd, zal toenemen.

Hoewel deze schoolverlatersenquête het inzicht heeft vergroot in de arbeidsmarktpositie van de betreffende schoolverlaters en de aansluitingsproblematiek in Midden-Limburg, behoeft het onderzoek evenwel een vervolg. Om na te gaan of de waargenomen verschillen tussen schooltypen en examenjaren op toevallige discrepanties of structurele ontwikkelingen berusten moeten er geregeld schoolverlatersenquêtes worden gehouden. Voor een goed begrip van de doorstroming van schoolverlaters op de arbeidsmarkt is het zinvol de huidige onderzoekspopulatie over enkele jaren opnieuw te benaderen. Tenslotte is voor een totaal overzicht van de arbeidsmarktpositie en de aansluitingsproblematiek van de schoolverlaters op zijn minst vereist, dat ook de vraagzijde van de arbeidsmarkt in beeld wordt gebracht. 


\section{HET ONDERZOEKSPLAN}

Voordat de probleemstelling en de onderzoekspopulatie van dit onderzoek worden besproken, wordt eerst een achtergrondbeschouwing gegeven met betrekking tot de aansluiting tussen het onderwijs en de arbeidsmarkt in het algemeen en de knelpuntenproblematiek (moeilijk vervulbare vacatures) die hiervan het gevolg is in het bijzonder.

\subsection{De aansluitingsproblematiek tussen onderwijs en arbeidsmarkt ${ }^{7}$}

Met het weer aantrekken van de economische groei is het kwalitatief uiteenlopen van vraag en aanbod op de arbeidsmarkt de laatste jaren weer in het middelpunt van de belangstelling komen te staan. Aan de ene kant staat nog steeds bijna $12 \%$ van de beroepsbevolking bij de arbeidsbureaus als werkloos ingeschreven. Maar aan de andere kant wordt er ook gesproken van tekorten aan bepaalde vakmensen. Bovendien geldt dat niet alleen bekeken moet worden hoe de bestaande scholingsproblemen op de arbeidsmarkt bestreden kunnen worden. Minstens zo belangrijk is de vraag wat er gedaan moet worden om toekomstige scholingsproblemen te voorkómen.

In de praktijk is er nogal eens sprake van enige verwarring over wat men precies verstaat onder aansluitingsproblematiek. Soms wordt gedoeld op het tekortschieten van het leerplan van een bepaalde (vak)opleiding in vergelijking met hetgeen in de werkpraktijk van een schoolverlater wordt verwacht. $\mathrm{Er}$ is hier sprake van een kwalitatief scholingsprobleem. Daarnaast doen zich echter ook kwantitatieve scholingsproblemen voor. Deze treden op wanneer er een tekort is aan arbeidskrachten voor een bepaald soort functies, terwijl er tegelijkertijd sprake is van een overschot aan arbeidskrachten in een andere beroeps- of opleidingsrichting.

Ook vanuit een andere invalshoek kunnen scholingsproblemen verder worden onderscheiden. We kijken dan naar de plaats waar scholingsproblemen zich manifesteren. Daarbij kan een onderscheid worden gemaakt tussen scholingsproblemen op de arbeidsmarkt en scholingsproblemen in de werksituatie. Er is sprake van scholingsproblemen op de arbeidsmarkt, wanneer werklozen niet voldoende, te hoog of verkeerd zijn opgeleid voor de functies, waarvoor er een tekort aan arbeidskrachten bestaat.

7. De Grip (1988), blz. 7-32, 69. 
Men spreekt in dit verband wel van een open aansluitingsprobleem. Scholingsproblemen kunnen echter ook in de werksituatie optreden. Dit is het geval wanneer een werknemer een onvoldoende, te hoge of verkeerde opleiding heeft gevolgd voor de functie waarin hij of zij werkzaam is. In dat geval spreken we van een (voor de arbeidsmarkt) verborgen aansluitingsprobleem. Bij een te lage opleiding is er sprake van overbenutting; bij een te hoge opleiding van onderbenutting.

Er kan eveneens onderscheid worden gemaakt tussen horizontale en verticale scholingsproblemen. Verschillen in scholingsrichting (of beroepsgroepen) hebben betrekking op horizontale, verschillen in scholingsniveau op verticale scholingsproblemen.

Strikt genomen is het begrip scholingsproblemen minder ruim dan het begrip aansluitingsproblemen. In dit rapport worden deze twee begrippen echter door elkaar gebruikt. Dit betekent dat uitgegaan wordt van een ruime definitie van scholingsproblemen, waarin naast de puur vaktechnische aspecten (kennis en praktische vaardigheden) ook andere (sociale) vaardigheden een rol kunnen spelen, zoals collegialiteit, flexibiliteit en omgang met klanten. 8

Scholingsproblemen kennen in feite twee aspecten. Enerzijds het bestaan van knelpunten op de arbeidsmarkt, in de zin van tekorten aan mensen met een bepaalde opleiding of werkervaring. Anderzijds het bestaan van een hoge werkloosheid bij een andere beroeps- of opleidingsgroep. In dit rapport zal met name de knelpuntenproblematiek worden belicht.

Een indicatie van de omvang van de knelpuntenproblematiek in Nederland kan worden gekregen op basis van gegevens met betrekking tot moeilijk vervulbare vacatures. Tabel 1.1 .9 geeft enig inzicht in de achtergronden van moeilijk vervulbare vacatures. Uit deze tabel blijkt dat de door werkgevers ervaren knelpunten op de arbeidsmarkt niet louter in beeld kunnen worden gebracht door het aantal werklozen en vacatures in een bepaalde beroepsgroep tegen elkaar af te zetten. Werkgevers spreken ook van knelpunten wanneer ze de werklozen die solliciteren niet geschikt vinden voor de bij hen openstaande vacatures. In het kader van dit onderzoek onder schoolverlaters van het (Kort) MBO zijn de achtergronden van de volgende beroepsgroepen van belang.

\footnotetext{
8. Zie ook Van Hoof (1987).

9. De Grip (1988), blz. 28.
} 
Wat betreft administratieve functies, evenals metaal- en electrotechnische beroepen blijken werkgevers met name te kampen met een tekort aan sollicitanten. Bij de commerciële en dienstverlenende functies ontstaan daarentegen juist knelpunten doordat de sollicitanten ongeschikt zijn.

Tabel 1.1. Achtergronden van moeilijk vervulbare vacatures, in procenten

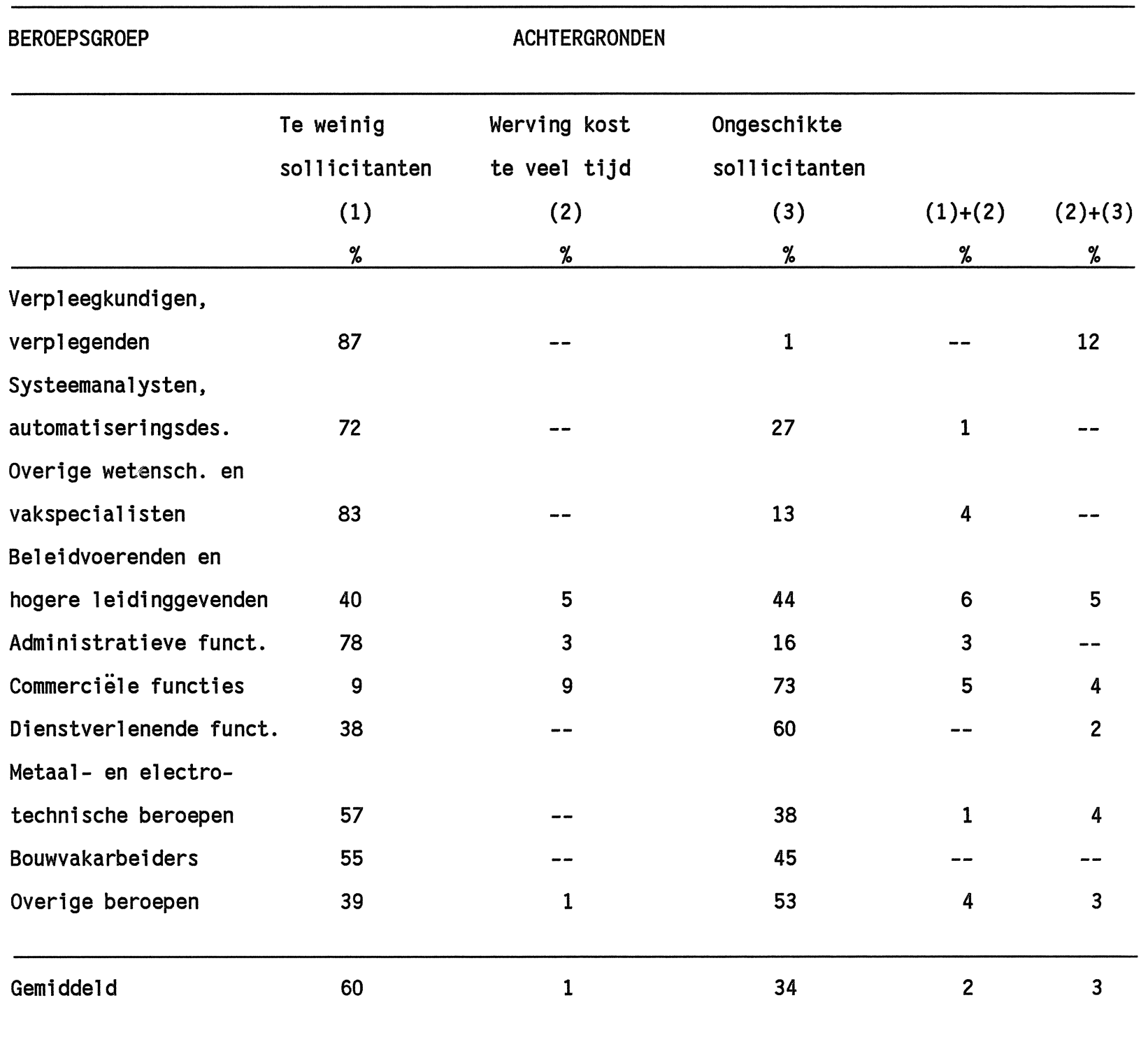

Bron: Van Ours (1987)

Van Paridon (1987) heeft op basis van een arbeidsmarktindicator, die berekend is aan de hand van werkloosheidspercentages voor bepaalde opleidingsniveaus en -richtingen, geprobeerd een typering van de arbeidsmarktsituatie te geven voor deze opleidingsniveaus en -richtingen (zie tabel 1.2.). 
Tabel 1.2. Arbeidsmarktindicator* schoolverlaters naar opleidingsniveau en -richting (cijfers mei 1987)

OPLEIDING

Basisonderwijs ('dropouts')

MAVO

HAVO

VWO

LBO

W.o. LTS

LEAO

MBO

w.o. MTS

- werktuigbouwkunde

- energietechniek

- electronica

- procestechniek

MEAO

- administratief

- commercieel

- bestuurlijk

- secretarieel

- toeristisch

HBO

w.o. HTS

- bedrijfskunde

- electrotechniek

- informatica

- werktuigbouwkunde

HEAO

- bedrijfseconomie

- bedrijfsinformatica

- commerciële economie

- economisch juridisch

- economisch linguïstisch

Wo

w.o. Technische wetenschappen

Economische wetenschappen

ARBEIDSMARKTINDICATOR

373

199

160

126

243

125

164

397

65

52

29

78

89

130

115

127

105

221

227

173

59

34

48

22

38

56

52

36

70

110

104

159

83

96

* De arbeidsmarktindicator is berekend volgens onderstaande schaal:

Werkloosheidspercentage

(gecorrigeerd)
Arbeidsmarktindicator arbeidsmarktsituatie

$\begin{array}{rr}0-3 \% & 0-50 \\ 3-5 \% & 51-83 \\ 5-7 \% & 84-117 \\ 7-9 \% & 118-150 \\ >9 \% & >150\end{array}$

groot tekort

tekort

evenwicht

overschot

groot overschot 
Tabel 1.2. laat zien dat voor een aantal specifieke studierichtingen in het technisch en economisch-administratief middelbaar (en hoger) beroepsonderwijs de schoolverlatersmarkt momenteel reeds krap genoemd kan worden. De grote verschillen tussen de werkloosheidspercentages van verschillende opleidingen wijzen er bovendien op dat er naast de momenteel actuele aansluitingsproblemen op de arbeidsmarkt eveneens sprake is van een nog veel grotere potentiële scholingsproblematiek, die ongetwijfeld actueel zal worden wanneer de arbeidsmarkt in zijn algemeenheid door het verder aantrekken van de vraag, of het afnemen van het aanbod van arbeid kwantitatief weer wat meer in evenwicht komt.

Wat dit betreft is het ook van belang prognoses te maken van de toekomstige verschuivingen in de werkgelegenheid en de verwachte aanbod- of vraagoverschotten voor de verschillende opleidingsrichtingen en -niveaus. Recentelijk heeft het Centraal Planbureau (1987) op een vrij globaal niveau dergelijke prognoses opgesteld. Uit deze cijfers blijkt dat er tekorten worden verwacht voor middelbaar en hoger opgeleide technici, hoger geschoolde administratief en/of economisch opgeleiden en verzorgend personeel met een MBOopleiding. Daarbij moet wel worden bedacht dat het hier om een lange-termijn prognose (tot het jaar 2000) gaat. Vanzelfsprekend gaat een dergelijke prognose met grote onzekerheden gepaard, maar de ramingen mogen toch wel als richtinggevend worden beschouwd.

\subsection{Onderzoeksopzet}

\subsubsection{Aanleiding en doel 1 stell1 ing onderzoek}

Bij de presentatie door de Kamer van Koophandel Midden-Limburg van de cijfers van de ERBO-enquête 10 (1985) bleek niet alleen dat de werkgelegenheid weer was toegenomen, maar ook dat bepalde vacatures moeilijk vervulbaar waren. Circa een vijfde deel van de bedrijven die in dat jaar nieuw personeel hadden aangenomen, ondervond expliciete problemen bij de vacaturevervulling als gevolg van de gestelde opleidingseisen. Uit de ERBO-enquête bleek eveneens dat een derde van de bedrijven, die verwachtten dat zij in 1986 nieuw personeel aan zouden nemen, dergelijke vacatureproblemen voorzag. Naar de mening van deze werkgevers zouden zich, met name bij productietechnische en in-en verkoopfuncties, knelpunten bij het vervullen van

10. $E R B O=$ Enquête Regionale Bedrijfsontwikkeling. 
vacatures gaan voordoen. Daarbij zou het vooral gaan om functies waarbij MBO als opleidingsniveau is vereist. Daar de werkgelegenheid in Midden-Limburg sinds 1985 verder is toegenomen, is het niet onwaarschijnijjk dat de afgelopen jaren ook het aantal moeilijk vervulbare vacatures in deze regio is gestegen.

Naar aanleiding van de uitkomsten van de genoemde ERBO-enquête achtte het COA Midden-Limburg het zinvol deze problematiek nader te analyseren, op basis van een enquête onder de schoolverlaters van de MBO-sectoren, waarvoor de grootste knelpunten werden gesignaleerd. In het overleg tussen het COA Midden-Limburg en het ROA is als doelstelling geformuleerd, dat deze schoolverlatersenquête een representatief beeld zou moeten schetsen van de arbeidsmarktpositie van de schoolverlaters en de aansluiting van de door hen gevolgde opleiding op hun huidige werksituatie. Het onderzoek zou in ieder geval inzicht zou moeten geven in vragen als:

- hoe ervaren schoolverlaters de aansluiting onderwijs-arbeid?;

- welke tekorten constateren de schoolverlaters zelf in de door hen gevolgde opleidingen?;

- welke lacunes kan men waarnemen ten aanzien van de opvang door bedrijven?

Uit de antwoorden op deze vragen zou het COA Midden-Limburg, in een later stadium, conclusies moeten kunnen afleiden ten aanzien van de vraag of bedrijven aan instromende schoolverlaters bepaalde vormen van bijscholing zouden moeten aanbieden. Bovendien zou de enquête mede voor de scholen een handvat moeten bieden voor de vraag of $z i j$, bijvoorbeeld in het kader van de SVM-operatie11, bepaalde opleidingen zouden moeten aanpassen of nieuwe opleidingsrichtingen zouden moeten opzetten.

Hierbij dient wel opgemerkt te worden dat een enquête onder schoolverlaters vanzelfsprekend geen volledig antwoord kan geven op de bovengenoemde vragen met betrekking tot de aansluiting tussen onderwijs en arbeid en het daarop gebaseerde scholingsbeleid. Voor een vollediger beeld van de aansluitingsproblemen in Midden-Limburg moeten immers in ieder geval ook de werkgevers worden benaderd. Daarnaast kunnen overheidsinstanties worden geraadpleegd wat betreft hun beleidsvoornemens op het terrein van onderwijs en arbeid en eventueel ook schooldecanen, (aankomende) leerlingen en hun ouders wat betreft de factoren die een rol spelen bij de school-en beroepskeuze.

11. SVM = Sectorvorming en Vernieuwing van het middelbare beroepsonderwijs. 
1.2.2. Afbakening_en_operational isatie van probleemstell ling en onderzooekspoppulat_ịe

De invalshoek, van waaruit de aansluitingsproblematiek en de arbeidsmarktpositie van de schoolverlaters worden beoordeeld, kan verschillen. Werkgevers, aan de vraagzijde van de arbeidsmarkt, beoordelen bijvoorbeeld de aansluiting tussen onderwijs en arbeidsmarkt naar de mate waarin zij vacatures goed en snel kunnen vervullen; de zogenaamde knelpuntenproblematiek. Vanuit de aanbodzijde beoordelen de schoolverlaters hun arbeidsmarktpositie en de aansluiting tussen onderwijs en arbeidsmarkt voor een belangrijk deel naar de mate waarin zij met een bepaalde (beroeps)opleiding een bepaalde startfunctie ( $c . q$. een beroepsloopbaan) kunnen bemachtigen.

Oordelen over de kwalitatieve aansluiting tussen opleidingen en de arbeidsmarkt is vanzelfsprekend subjectief. Het gaat tenslotte om meningen van mensen die een bepaalde plaats innemen in de maatschappij. Waarschijnijjk stellen werkgevers andere prioriteiten in hun beschouwingen over de aansluitingsproblematiek dan de schoolverlaters zelf. In deze schoolverlatersenquête staat de optiek van de schoolverlaters, in casu de aanbodzijde, centraal. Natuurlijk zijn de resultaten van de enquête wel degelijk voor beide zijden van de arbeidsmarkt van belang. Juist ook, omdat de aansluiting van de beroepsopleidingen die in het onderzoek zijn betrokken, vanuit de vraagzijde als problematisch worden ervaren.

Het volgen van onderwijs heeft voor de leerlingen verschillende functies:

- de persoonlijke ontplooiing en deelname aan het matschappelijk leven in het algemeen;

- het voorbereiden op de deelname aan vervolgonderwijs;

- het voorbereiden op de toekomstige beroepsuitoefening.

In dit onderzoek wordt voornamelijk aandacht geschonken aan de laatstgenoemde doelstelling van het onderwijs. Echter, ook de aansluiting van de opleiding op het vervolgonderwijs wordt in het kort belicht.

Zoals gezegd komt uit de ERBO-enquête van 1985 naar voren dat vooral vacactures voor productie-technische en in- en verkoopfuncties, met name waarvoor een MBO-opleiding wordt gevraagd, moeilijk vervulbaar zijn. Daarom is gekozen voor een enquête onder de schoolverlaters van de volgende schooltypen van het MBO: MEAO, MMO, MTS en KMBO-Metaaltechnieken. Het KMBO is in het onderzoek opgenomen ter vergelijking met het MBO. 
Tabel 1.3. Onderzoekspopulatie naar opleidingsrichting en schooltype, in procenten $(N=816)$

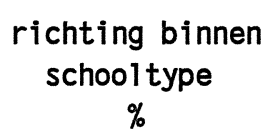

$\%$ school type

$\%$

$\begin{array}{lr}\text { bouwkunde } & 9 \\ \text { energierichtingen } & 15 \\ \text { electronica } & 27 \\ \text { procestechniek } & 9 \\ \text { weg- en waterbouwkunde } & 6 \\ \text { werktuigbouwkunde } & 34 \\ & --- \\ \text { TOTAAL MTS } & 100\end{array}$

\section{9}

15

27

9

6

34

100

58

bedrijfsadministratieve richting 55

commerciële richting 11

bestuurlijke richting 12

vrije richting 22

TOTAAL MEA0 12

22

100

$---$

100

10

42

27

31

$---$

100

10

$\overline{100}$

TOTAAL (Kort) MBO

Bron: ROA

12. Hoewel de bedrijfsadministratieve en bestuurlijke richtingen op het eerste gezicht weinig met in-/verkoop te maken lijken te hebben, zijn deze richtingen toch opgenomen in het onderzoek. Deels omdat de vakken, die men volgt bij deze richtingen, nauwelijks afwijken van de vakken bij de commerciële en vrije richtingen. Deels omdat schoolverlaters uit eerstgenoemde richtingen ook in-/verkoopfuncties bezetten. Bovendien zijn er aanwijzingen dat er ook voor de bedrijfsadministratieve richting knelpunten op de arbeidsmarkt bestaan.

13. Aangezien het KMBO ter vergelijking zou dienen van het MBO is besloten die richtingen in het onderzoek op te nemen, die het beste aansluiten bij zowel de probleemstelling als de inhoud en het niveau van het MBO. Dit geldt voor de genoemde richtingen in de metaltechnieken. 
Het onderzoek heeft zich beperkt tot de voltijdse opleidingen en betreft de regio Midden-Limburg, in casu Roermond en omstreken.14 Tabe1 1.3. geeft een beeld van de samenstelling van de populatie. MTS-ers vormen de grootste groep (58\%), gevolgd door respectievelijk MEAO-ers (22\%), MMO-ers (10\%) en KMBO-ers $(10 \%)$.

In het kader van dit onderzoeksproject zijn de schoolverlaters van de hierboven genoemde schooltypen en opleidingsrichtingen uit de examenjaren $1987(N=413)$ en $1988(N=403)$ benaderd. Het betreft hier alleen gediplomeerde schoolverlaters. Schoolverlaters zonder diploma vormen immers geen juiste maatstaf voor de beoordeling van de mate waarin een bepaalde opleiding aansluit op de arbeidsmarkt. Bovendien hebben drop-outs op de arbeidsmarkt met specifieke problemen te maken.

In het onderzoek staan de verschillen tussen de schooltypen met betrekking tot de arbeidsmarktpositie van de schoolverlaters en de aansluiting tussen de opleiding en de arbeidsmarkt centraal. Daarbij krijgt de start van de beroeps loopbaan de meeste aandacht. 15 Het betreft immers schoolverlaters uit de examenjaren 1987 en 1988. Deze hebben de opleiding op het moment van enquêteren respectievelijk circa 10 en 22 maanden geleden verlaten.

In de schoolverlatersenquête is vooral gekeken naar de huidige situatie, waarin de schoolverlaters zich bevinden. Vooral de actuele arbeidsmarktpositie en aansluiting tussen opleiding en arbeidsmarkt worden geanalyseerd. Er komen slechts enkele retrospectieve elementen aan bod met betrekking tot de periode mei 1987 tot en met januari 1989. Voor zover verwachtingen worden behandeld, betreffen zij alleen de korte termijn.

Op basis van de aanleiding en de doelstelling van dit onderzoek (zie subparagraaf 1.2.1.), evenals voorgaande afbakening kunnen de onderzoekspopulatie en de probleemstelling als volgt worden geformuleerd:

14. De MBO-scholen uit de subregio Weert zijn niet in dit onderzoek betrokken. Wat betreft de MTS en het MMO was dit ook niet mogelijk, aangezien deze schooltypen (nog) niet zijn vertegenwoordigd in Weert. Het MEAO bestaat nog maar enkele jaren in Weert. Hiervan zijn pas in 1988 de eerste schoolverlaters afgestudeerd, zodat geen schoolverlaters uit het examenjaar 1987 opgenomen konden worden. Om deze redenen zijn alleen de deelnemende schooltypen uit Roermond in het onderzoek opgenomen.

15. In anglo-saksische landen wordt dergelijk onderzoek wel "first destination survey" genoemd. 


\section{Onderzoekspopulatie:}

alle gediplomeerde schoolverlaters uit de examenjaren 1987 en 1988 van de voltijdse opleidingen van het MEAO (m.u.v. secretariaatsrichting), het MMO-C (inclusief de groothandelsrichting), de MTS en het KMBO-Metaaltechnieken in Midden-Limburg (i.c. Roermond/Heythuysen).

\section{Probleemstelling (bestaande uit twee deelvragen):}

- welke verschillen bestaan er tussen de betreffende schoolverlaters in hun arbeidsmarktpositie?;

- welke verschillen bestaan er tussen de betreffende schoolverlaters met betrekking tot de aansluiting van de door hen gevolgde opleiding op hun huidige (start)functie?

Het conceptueel model in figuur 1.I. geeft aan welke factoren, aan de aanbodzijde van de arbeidsmarkt, van invloed kunnen zijn op zowel de arbeidsmarktpositie als de aansluiting van de gevolgde (Kort) MBO-opleiding op de huidige functie van de betreffende schoolverlaters. Daarnaast geeft dit model inzicht in de onderlinge relaties tussen deze factoren.

Figuur 1.I. Conceptueel model van de invloed van aanbodfactoren op de arbeidsmarktpositie en de aansluiting tussen opleiding en werk van de schoolverlaters

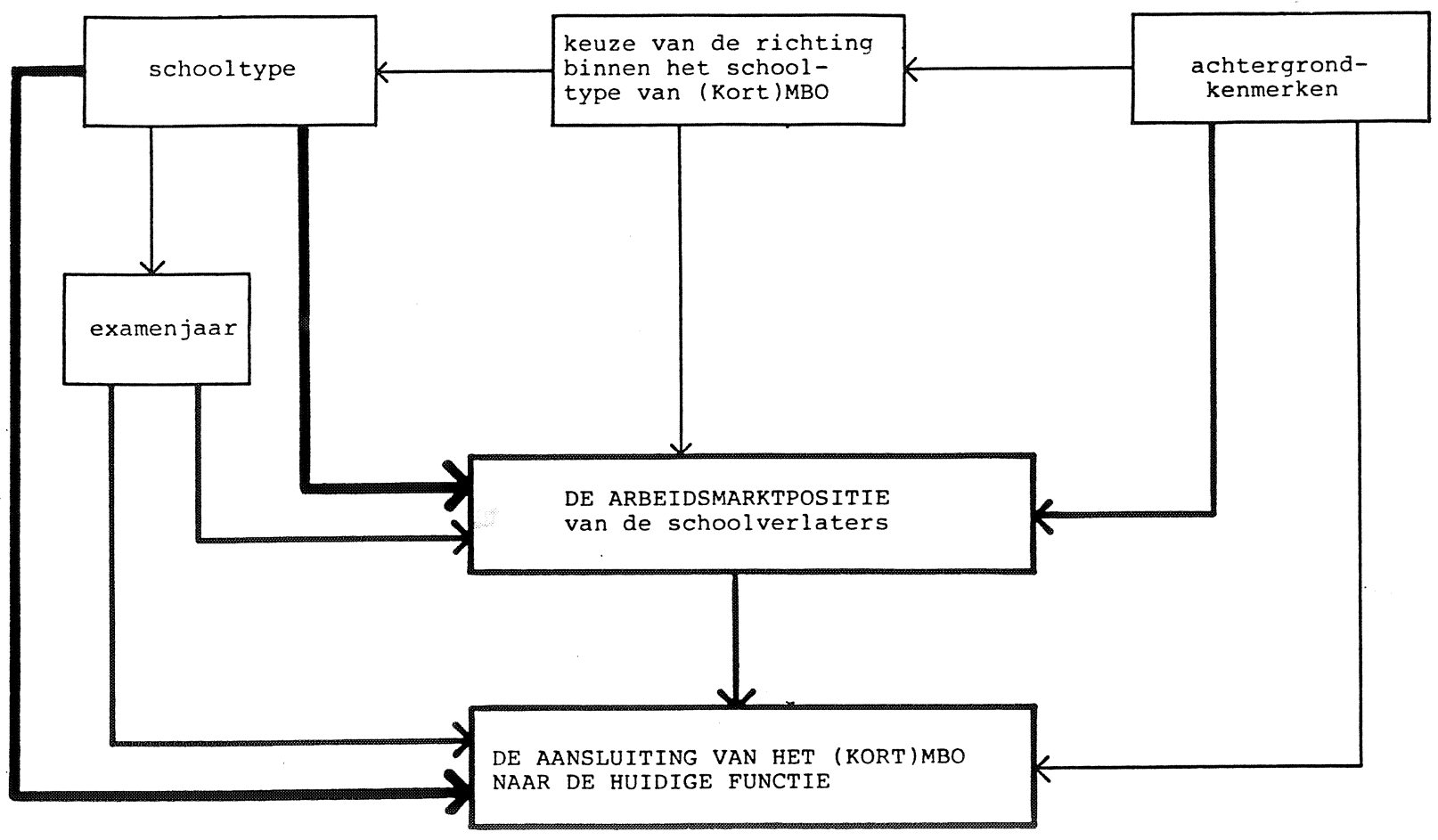


In dit onderzoek wordt, zoals gezegd, in de eerste plaats aandacht geschonken aan de invloed van het schooltype op beide genoemde vraagstukken. In de tweede plaats wordt bekeken welke rol het examenjaar (i.c. het jaar van afstuderen), waarin de schoolverlaters de opleiding hebben verlaten, bij de beantwoording van de twee deelvragen van de probleemstelling speelt. Ook enkele achtergrondkenmerken, zoals vooropleiding, geslacht, leeftijd en opleiding van de ouder(s) worden dikwijls als verklarende factoren gehanteerd. Dit geldt ook voor enkele factoren die te maken hebben met het proces rondom de keuze van de richting binnen een bepald schooltype van het (Kort) MBO.

De begrippen in het conceptueel model zijn verbijzonderd in een aantal concrete en direct te meten variabelen, die te zamen een indicatie vormen van de inhoud van het totale begrip. Deze variabelen worden dan ook wel indicatoren genoemd. Bij de bespreking van de resultaten van de schoolverlatersenquête worden derhalve niet alleen de globale begrippen besproken, maar ook de indicatoren die het betreffende begrip concretiseren.

\subsubsection{De schooolverlatersenquête}

Een schriftelijke schoolverlatersenquête is als onderzoeksinstrument voor een oriëntatie van de aanbodzijde van de scholingsproblematiek een voor de hand liggend meetinstrument. 16 De vragenlijst17 is als volgt opgebouwd. Het eerste gedeelte bevat een aantal algemene vragen voor alle respondenten. Deze vragen betreffen de factoren die een rol hebben gespeeld bij de keuze van de richting aan de gevolgde (Kort) MBO-opleiding, de achtergrond van de ouder(s), de activiteiten na het (Kort) MBO en de huidige (economische) situatie. Deze laatste variabele vormt de sleutelvariabele voor de verdere routing door de vragenlijst.

Het tweede gedeelte van de vragenlijst is bestemd voor werklozen, huisvrouwen of -mannen en degenen die niet tot één van de andere categorieën behoren. In deel drie van het vragenformulier worden vragen gesteld aan degenen die na het (Kort) MBO een vervolgopleiding hebben gekozen.

16. Segers (1983), blz. 151.

17. De vragenlijst is als bijlage 2 aan dit rapport toegevoegd. Het betreft de versie voor de schoolverlaters van de MTS uit 1988 (inclusief de bijbehorende begeleidende brieven). 
De dienstplichtigen (militair of vervangend) komen in het vierde gedeelte aan bod. Deze drie bovengenoemde categorieën worden slechts enkele vragen gesteld. Op grond van de probleemstelling is meer aandacht besteed aan de betaald werkenden in deel vijf van de vragenlijst. Na enkele algemene kenmerken over hun functie krijgen deze schoolverlaters vragen voorgelegd over hun beroep, het bedrijf waar zij werkzaam zijn, de geografische mobiliteit, hun inkomsten, de tevredenheid met de wekelijkse arbeidsduur, het overwerk, de aansluiting tussen opleiding en werk, de begeleiding door de werkgever en het eventueel volgen van cursussen. Deze groep betaald werkenden 18 beoordeelt tenslotte in het zesde deel van het vragenformulier de kwalitatieve aansluiting tussen de gevolgde (Kort) MBO-opleiding en de huidige functie. Hier komen aspecten aan bod zoals de theoretisch-technische kennis, de taal- en praktische vaardigheden, de behoefte aan extra kennis en vaardigheden, de stage en de functiekenmerken. Tenslotte beantwoorden alle respondenten de slotvragen. Deze hebben betrekking op de behoefte aan een samenvatting van de enquêteresultaten, de medewerking aan een vervolgenquête en opmerkingen over de enquête zelf.

De meeste vragen hebben gesloten antwoordcategorieën. De behoefte aan met name feitelijke gegevens en de frequenties van deze gegevens, het verhogen van de betrouwbaarheid, het zoveel mogelijk elimineren van het probleem van de tel- of analyse-eenheid en de praktische voordelen bij de invoer, verwerking en analyse van de resultaten hebben tot deze keuze geleid. Enkele cruciale vragen over bijvoorbeeld de huidige functie en de bedrijfssector zijn evenwel open gesteld en in een later stadium gecodeerd, waarna deze alsnog als gesloten categorie in het databestand zijn ingevoerd. Daarbij is aansluiting gezocht bij de definities en classificaties, zoals die door het Centraal Bureau voor de Statistiek en de Kamers van Koophandel worden gehanteerd.19 Dit heeft als voordeel dat de resultaten in hoge mate kunnen worden vergeleken met enkele veelgebruikte statistieken. 20

18. Ook degenen die na hun (Kort) MBO-opleiding langer dan een half jaar bij één werkgever hebben gewerkt (en niet tot de huidige werkenden behoren) hebben de vragen over de kwalitatieve aansluiting beantwoord.

19. Definities en classificaties m.b.t. (economische) bezigheden, beroep, bedrijfsklassen en regio's zijn terug te vinden in het bijlagenboek.

20. Hierbij kan naast enkele sociaal-economische en onderwijsstatistieken van het CBS, worden gedacht aan de statistische gegevens die in het kader van het landelijke RUBS-project (Registratie van de Uitstroom en de Bestemming van Schoolverlaters) zijn verzameld. 
Het overgrote deel van de gestelde vragen is direct van aard. Dat wil zeggen, dat de afstand tussen de vraag en het theoretische doel klein is en voor de respondenten vrijwel rechtstreeks inzichtelijk. Een aantal vragen met betrekking tot het vaststellen of iemand tot de categorie werklozen behoort, de geografische en arbeidsmarktmobiliteit, de branche waarin men werkzaam is en de kwalitatieve aansluiting tussen de gevolgde opleiding en de huidige functie hebben daarentegen een indirecter karakter.

Een aantal school- en persoonlijke gegevens van de populatie zijn vóóraf anoniem (onder nummer) door de participerende scholen aan het ROA verstrekt. Enerzijds om meer ruimte te hebben voor andere vragen, anderzijds om na te gaan in hoeverre de respons in bepaalde opzichten selectief is (zie ook subparagraaf 1.3 .1$.$) .$

Het ROA en het COA Midden-Limburg achten de anonimiteit van de schoolverlaters van zwaarwegend belang. Daarom is er een procedure toegepast, waarbij de gegevens van de scholen en de schoolverlaters anoniem konden worden verwerkt. Het namen-en adressenbestand is derhalve geheel gescheiden van de informatie die de schoolverlaters hebben verstrekt.

Medio januari 1989 zijn de originelen van de vragenlijsten, de begeleidende brief voor de schoolverlaters, de antwoordenveloppen, alsmede het draaiboek$^{21}$ voor de verzending van de enquête naar de administraties van de betrokken scholen gestuurd. In de week vóor de eerste verzending zijn de schooladministraties eveneens bezocht om de procedure rond de verzending toe te lichten. Zo'n mondelinge toelichting verhoogt de motivatie bij diegenen die zorg moeten dragen voor de uitvoering van de verzending in hoge mate. Bovendien kunnen ook de kleinste details uit het draaiboek goed worden doorgesproken.

Om de enquête zoveel mogelijk te laten aansluiten bij de leefwereld van de schoolverlaters en daarmee de respons te verhogen, is er voor ieder deelnemend schooltype en ieder examenjaar een afzonderlijke versie gemaakt van de vragenlijst en de begeleidende brieven. De begeleidende brieven zijn, om dezelfde reden, op briefpapier van de school afgedrukt.

21. Alle versies van de vragenlijst en van de begeleidende brieven alsmede de antwoordenveloppe en het draaiboek zijn opgenomen in het bijlagenboek. 
Er zijn twee perioden van gegevensverzameling geweest. In de laatste week van januari zijn de schoolverlaters voor het eerst benaderd. Medio februari zijn aan de schoolverlaters die de eerste keer niet hebben gereageerd de vragenlijsten opnieuw toegestuurd. Vrijdag 10 maart is de tweede, en laatste, inzendtermijn gesloten.

\subsubsection{De rapportage}

De antwoorden van de ingevulde vragenlijsten zijn door het ROA met behulp van een daartoe ontwikkeld softwarepakket handmatig ingevoerd. Het aldus verkregen databestand is vertaald naar een statistisch verwerkingsprogramma (SPSS-PC). Met behulp van dit programma zijn frequentie- en kruistabellen vervaardigd (de grafieken met behulp van het grafische presentatieprogramma Harvard's Graphics). Gezien de grote verscheidenheid aan beschikbare gegevens heeft een selectie uit het scala van mogelijke tabellen moeten plaatsvinden. De uitsplitsing naar de verschillende schooltypen is bij deze keuze van de te vervaardigen (kruis)tabellen het belangrijkste selectiecriterium geweest. Daarnaast zijn tabellen gemaakt van opvallende correlaties tussen variabelen. In veel rapporten wordt vaak standaard een onderscheid gemaakt tussen mannen en vrouwen. Aangezien in dit onderzoek slechts één op de tien respondenten een vrouw betreft en deze groep vrouwen zeer ongelijk over de schooltypen is verdeeld, is er hier van afgezien, binnen de schooltypen, het aantal respondenten naar geslacht onder te verdelen.

De frequentietabellen bevatten absolute cijfers en percentages, de kruistabellen naast de absolute cijfers ook rij- en kolompercentages. User-missing values22 zijn, omwille van de overzichtelijkheid, niet opgenomen in de tabellen, wanneer er slechts sprake is van een uitval van kleine aantallen. Uiteraard kunnen niet alle tabellen in het rapport zelf worden opgenomen. Daarom zijn deze in een apart tabellenboek gebundeld. In het rapport zelf staan de belangrijkste, tabellen in vereenvoudigde vorm. Bij de bespreking van de resultaten van de schoolverlatersenquête wordt telkens verwezen naar de betreffende tabellen uit het tabellenboek.

22. Missing values is een term die wordt gebruikt voor ontbrekende waarden. Er bestaan system missing values en user missing values. System missing values ontstaan doordat bepaalde vragen niet aan alle respondenten worden gesteld. Respondenten hebben op deze vragen niet kunnen "scoren". User missing values hebben betrekking op het niet (juist) invullen van de vraag door de respondent. 
Bij het opstellen van de tabellen voor het tabellenboek is informatiedichtheid als voornaamste criterium gekozen. Daarentegen is overzichtelijkheid het belangrijkste criterium geweest bij de weergave van de resultaten in het rapport.

Evenals bij het vervaardigen van de tabellen, zijn de verschillen tussen de onderzochte schooltypen ook als uitgangspunt genomen bij de bespreking van de resultaten. Een belangrijke reden om niet primair het accent te leggen op het totaalbeeld is de oververtegenwoordiging van de MTS in de totale onderzoekspopulatie.

De verschillen tussen de schooltypen spelen op drie wijzen een rol. Ten eerste is bij de analyse bekeken of er verschillen zijn tussen het MBO enerzijds en het KMBO anderzijds. Daarbij is met name gelet op verschillen tussen de MTS en het KMBO (-metaaltechnieken). In de tweede plaats zijn de verschillen belicht tussen aan de ene kant de technische opleidingen MTS en KMBO en aan de andere kant de economisch-administratieve opleidingen MEAO en MMO. Tenslotte is aandacht besteed aan de verschillen tussen het MEAO en het MMO.

\subsection{Technische evaluatie van de schoolverlatersenquête}

\subsubsection{Respons en representativiteit}

In totaal zijn er 816 schoolverlaters van de participerende richtingen aan het (Kort) MBO uit de examenjaren 1987 en 1988 in Midden-Limburg benaderd. De totale respons bedraagt, na beide metingen, voor de gehele populatie $76 \%$. Dit is een zeer hoge respons. Zeker wanneer de omvang van de vragenlijst in ogenschouw wordt genomen. De respons voor de vier afzonderlijke schooltypen loopt uiteen van $64 \%$ voor het $\mathrm{KMBO}$, via $70 \%$ voor het $\mathrm{MMO}$, tot $79 \%$ voor zowe 1 het MEAO, als de MTS. Hoewel de schoolverlaters uit het examenjaar 1988 in het algemeen nauwelijks vaker gereageerd hebben dan de schoolverlaters uit 1987 , is de respons van schoolverlaters van het MEAO uit het examenjaar 1988 wel beduidend hoger dan die uit 1987 (zie figuur 1.II.).

Opgemerkt kan nog worden dat verhoudingsgewijs veel schoolverlaters uit het examenjaar 1988 na het rappel hun vragenlijst hebben geretourneerd. 
Figuur 1.II. Respons, per schooltype, gedifferentieerd naar examenjaar, in procenten

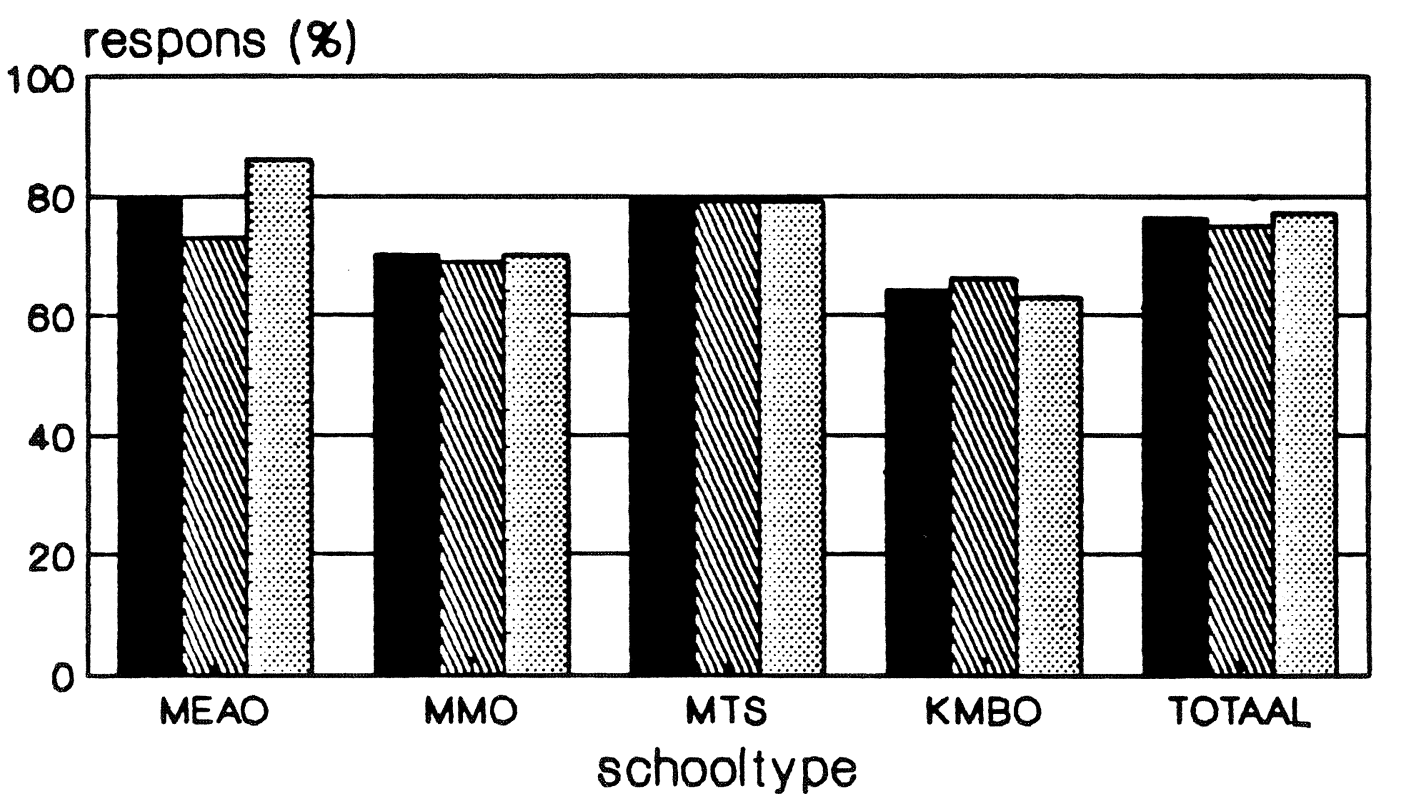

1987 on 1988 AIIIII $1987 \% 1988$

Bron: ROA (1088)

Een hoge respons is belangrijk. Want, hoe hoger de respons, met des te meer zekerheid iets gezegd kan worden over de resultaten. Maar een hoge respons alleen is niet voldoende. Het is eveneens van belang om te weten of de respons representatief is. De respons moet namelijk een afspiegeling zijn van de totale populatie. Of dit voor deze enquête het geval is, is aan de hand van door de deelnemende scholen verstrekte gegevens bekeken voor de volgende kenmerken: schooltype, examenjaar, richting, geslacht en vooropleiding.

Gezien de hoge respons bij alle schooltypen kan worden geconcludeerd dat de respons voor alle vier schooltypen als representatief mag worden beschouwd. Aangezien met name de verschillen tussen de schooltypen bij de bespreking van de resultaten centraal staan, is toetsing van de selectiviteit tussen de schooltypen niet aan de orde.

De helft van de respondenten heeft de (Kort) MBO-opleiding in 1987 verlaten, de andere helft in 1988. Deze percentages zijn vrijwel identiek aan de percentages in de totale benaderde populatie. Op het punt van examenjaar is de respons dus eveneens representatief. 
Voor wat betreft de representativiteit van de respons op het punt van de opleidingsrichtingen binnen de vier schooltypen kan het volgende worden opgemerkt. In het examenjaar 1987 zijn binnen het MEAO de commerciële en bestuurlijke richtingen ondervertegenwoordigd. Wanneer wordt gekeken naar beide afstudeerjaren geldt dit alleen nog voor de bestuurlijke richting. Het MMO participeert in dit onderzoek slechts met één richting. Voor deze richting geldt, dat zij lichtelijk is ondervertegenwoordigd. Binnen de MTS zijn, over het algemeen, de responsverschillen tussen de richtingen niet zo groot. Alleen de energierichtingen zijn iets ondervertegenwoordigd. Dit geldt met name voor het examenjaar 1987. Binnen de participerende afdeling Metaaltechnieken van het KMBO is de richting verspanen, met name in het examenjaar 1988, ondervertegenwoordigd. Over het geheel genomen is de respons naar richting echter nauwelijks selectief.

De representativiteit van de respons wat betreft geslacht is alleen voor de op dit punt relevante opleidingen bekeken; in casu het MEAO en het MMO. ZO'n $60 \%$ van de vrouwen komt van het MEAO en bijna één derde van het MMO. Voor het examenjaar 1987 is de respons wat betreft het kenmerk geslacht representatief. In de respons van de bestuurlijke richting aan het MEAO zijn vrouwen voor dat jaar echter wel enigszins ondervertegenwoordigd. In het examenjaar 1988 zijn vrouwen bij het MEAO in de respons oververtegenwoordigd en vrouwen van het MMO ondervertegenwoordigd. De conclusie luidt dat in het algemeen de respons wat betreft geslacht representatief is, met de gemaakte kanttekening voor de respons voor het examenjaar 1988.

Wanneer de respons op representativiteit van de vooropleiding (opleiding voorafgaand aan instroming in (Kort) MBO) wordt beschouwd, blijken de responsverschillen marginaal te zijn. Dit geldt ook op het niveau van de afzonderlijke schooltypen. 23 op het punt van de vooropleiding is de respons aldus representatief.

Er wordt nog wel eens gesteld, dat de respons naar de economische situatie van de respondent selectief kan zijn. Men verwacht dan dat werklozen minder geneigd zijn aan een schoolverlatersenquête deel te nemen, dan betaald werkenden. Aangezien in dit onderzoek alleen van de respondenten bekend is in welke economische situatie zij verkeren, kan op dit punt geen vergelijking worden gemaakt met de non-respons.

23. Aangezien het KMBO geen gegevens over de vooropleiding van haar schoolverlaters kon verstrekken, is bij het KMBO wat betreft vooropleiding een vergelijking tussen respons en non-respons achterwege gelaten. 
Uit werkloosheidscijfers van het Gewestelijk arbeidsbureau Midden-Limburg blijkt evenwel dat, in overeenstemming met de resultaten uit de schoolverlatersenquête, slechts weinig mensen met een technische of economisch-administratieve MBO-opleiding werkloos zijn.

Wat betreft de representativiteit naar regio kan het volgende worden opgemerkt. De respons is wat betreft de subregio Roermond representatief, aangezien alle technische en economisch-administratieve MBO-scholen uit deze subregio meedoen. Met betrekking tot de gehele regio Midden-Limburg is er wel sprake van enige selectiviteit, aangezien de MBO-scholen uit Weert en omgeving niet in het onderzoek zijn betrokken. Deels was dat ook niet mogelijk, daar er in Weert nog geen MTS is en het MEAO in Weert in 1987 nog geen schoolverlaters had. Bij het KMBO is wel de dependance in Heythuysen in het onderzoek opgenomen. Derhalve is, op de economisch-administratieve richting van het MBO voor het jaar $1988 \mathrm{na}$, de respons voor de gehele regio Midden-Limburg representatief te noemen.

Over het geheel gesproken kan, gezien bovenstaande opmerkingen over de afzonderlijke kenmerken, worden gesteld dat de respons een representatieve afspiegeling vormt van de totale benaderde groep schoolverlaters. Correcties voor een selectieve non-repons hebben dan ook niet plaatsgevonden.

\subsubsection{Beoordel ing van de vragenlij}

In de vragenlijst is een vraag opgenomen over de behoefte aan een samenvatting over de resultaten van deze schoolverlatersenquête. Bijna alle (94\%) respondenten blijken een dergelijke samenvatting op prijs te stellen. In deze behoefte bestaat weinig verschil tussen de verschillende schooltypen.

Ook is de respondenten gevraagd of $z i j$, te zijner tijd, bereid zijn mee te werken aan een vervolgenquête. Ruim $90 \%$ van de respondenten verklaart zich hiertoe bereid. Van de KMBO-ers is ruim driekwart bereid aan een vervolgenquête mee te werken. Voor de overige drie schooltypen ligt dit percentage rond het gemiddelde van $90 \%$. Uit deze hoge percentages blijkt evenwel de betrokkenheid van de onderzochte populatie bij dit onderzoeksterrein.

De respondenten is de mogelijkheid geboden om opmerkingen te plaatsen over de enquête in zijn gehee1. Bijna driekwart van de respondenten heeft geen opmerkingen. Dit geldt voor alle schooltypen en voor beide examenjaren. 
Circa zestig respondenten (= bijna $10 \%$ ) geven expliciet steun aan de (doeleinden van de) enquête. Dit is met name het geval bij de MEAO-ers en de MMO-ers. Vijftien respondenten geven aan dat niet alle vragen met "ja of nee" zijn te beantwoorden (minder gesloten vragen). Ruim twintig respondenten vinden dat er meer aandacht besteed moet worden aan de aansluiting van het gevolgde (kort) middelbaar beroepsonderwijs naar het vervolgonderwijs. Ook is er volgens een tiental respondenten te weinig aandacht besteed aan de ervaringen rondom de dienstplicht of het oprichten van een eigen bedrijf. Daarentegen hebben vier respondenten de vragenlijst te uitgebreid gevonden. Voor vijf respondenten is het niet duidelijk geweest of bij de vragen in het kader van de aansluiting tussen opleiding naar betaalde arbeid, de examenvakken moeten worden beoordeeld of alle vakken die men in de opleiding heeft gevolgd. Gemiddeld één op de twintig respondenten heeft een opmerking gemaakt die specifiek de gevolgde opleiding betreft en $z 0$ 'n $10 \%$ van de respondenten heeft "overige" zaken opgemerkt.

Naast deze directe beoordeling van de vragenlijst door de respondenten, kan het onderzoeksinstrument worden geëvalueerd aan de hand van geconstateerde moeilijkheden bij het invullen van de vragenlijst door de respondenten. Op deze plaats worden de meest in het oog springende punten behandeld. Voor een gedetailleerde evaluatie wordt verwezen naar het bijlagenboek.

Allereerst een opmerking over de vormgeving. Hoewel in eerste instantie is gekozen voor een vragenlijst op A5-format, is op grond van de criteria van leesbaarheid, handzaamheid en aantrekkelijke verzorging de voorkeur gegeven aan een vragenlijst op A4-formaat met een gekleurde, zwaardere, kaft.

Inhoudelijk kunnen de volgende kanttekeningen bij de vragenlijst worden geplaatst. Bij sommige vragen zouden enkele antwoordcategorieën kunnen worden toegevoegd, bij anderen enkelen worden geschrapt. Gezien het kleine aandeel van werklozen in deze populatie, hadden enkele vragen voor deze categorie achterwege gelaten kunnen worden. Daarentegen zou meer aandacht besteed kunnen worden aan de aansluiting van het (Kort) MBO naar het vervolgonderwijs. Wellicht zou het begin van het vragendeel voor de werkende schoolverlaters vereenvoudigd kunnen worden, zodat de routing voor degenen, die in loondienst werken, beter te volgen is. Daarnaast heeft een kleine $10 \%$ van de respondenten de vragen over de vooropleiding van de ouders niet willen of kunnen invullen. Over het algemeen blijkt de vragenlijst echter op juiste wijze te zijn ingevuld. 
Met betrekking tot de begeleidende brief voor de schoolverlaters kan de suggestie worden gedaan de enquêteprocedure met betrekking tot de anonimiteit uitvoeriger te beschrijven. Sommige respondenten hebben namelijk commentaar op het enquêtenummer dat achterop de vragenijist is aangebracht. Enkelen hebben dit nummer zelfs verwijderd! Om dubbeltellingen te voorkómen zijn de gegevens van deze laatste vragenlijsten niet in het databestand opgenomen. De betreffende respondenten zijn bij de tweede aanschrijving opnieuw benaderd.

Op grond van zowel de hoge én representatieve respons, als uit de grote behoefte aan een samenvatting en de grote bereidheid om aan een vervolgenquête mee te werken, alsmede vanwege het feit dat de meeste respondenten de vragenlijst op juiste wijze hebben ingevuld, kan worden geconcludeerd dat deze enquête, op deze punten, als onderzoeksinstrument geslaagd is. Uit het hiernavolgende verslag over de empirische resultaten van deze enquête, kan worden afgeleid welke waarde het onderzoeksinstrument heeft bij het beantwoorden van de vragen uit de probleemstelling. 


\section{EEN ALGEMENE KARAKTERISTIEK VAN DE SCHOOLVERLATERS}

Hoofdstuk 2 bevat een algemene karakteristiek van de schoolverlaters.24 In de eerste paragraaf worden enkele achtergrondgegevens van de schoolverlaters behandeld: geslacht, vooropleiding, leeftijd, alsmede opleiding en beroep van de ouder(s). Vervolgens worden de factoren besproken die bij de keuze van de opleidingsrichting aan het (Kort) MBO een rol hebben gespeeld.

\subsection{Enkele achtergrondkenmerken van de schoolverlaters}

\section{Geslacht}

Figuur 2.I. Percentage vrouwen, per schooltype

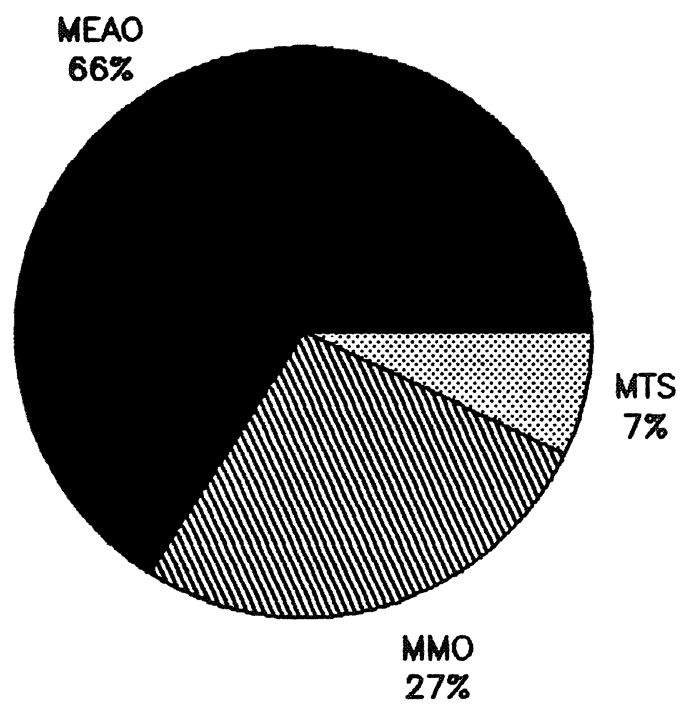

Bron: ROA (1989)

In dit onderzoek is het aantal vrouwen zwaar ondervertegenwoordigd. Zij nemen in de totale respons slechts 20 'n $11 \%$ in. Dit hangt natuurlijk sterk samen met de oververtegenwoordiging van de technisch geschoolden, in casu de MTS-ers. De kleine zeventig vrouwen die aan dit onderzoek hebben meegewerkt zijn zeer ongelijk verdeeld over de schooltypen (zie figuur 2.I.).

24. De karakteristiek heeft alleen betrekking op de respondenten (dus niet op alle benaderde schoolverlaters). 
Zo'n tweederde van de vrouwen komt van het MEAO en ruim een kwart van het MMO, tegenover slechts $7 \%$ van de MTS. Geen enkele vrouw heeft in 1987 of 1988 de afdeling Metaaltechnieken aan het KMBO (gediplomeerd) verlaten. Anders gezegd, van de respondenten van het MEAO en het MMO is ongeveer een derde deel vrouw, van de technisch geschoolden circa $1 \%$ ! 25

\section{$\underline{\text { Vooropleiding }}^{26}$}

Tabe1 2.1. Vooropleiding, per schooltype, in procenten

\begin{tabular}{|c|c|c|c|c|c|}
\hline VOOROPLEIDING & $\begin{array}{c}\text { MEAO } \\
\%\end{array}$ & $\begin{array}{c}\text { MMO } \\
\%\end{array}$ & $\begin{array}{c}\text { MTS } \\
\%\end{array}$ & $\begin{array}{c}\mathrm{KMBO}^{27} \\
\%\end{array}$ & $\begin{array}{c}\text { TOTAAL } \\
\%\end{array}$ \\
\hline LBO & 6 & 13 & 29 & 65 & 24 \\
\hline MAVO & 43 & 54 & 47 & 21 & 45 \\
\hline HAVO 4 , VWO $4 / 5$ & 2 & 7 & 4 & 3 & 4 \\
\hline HAVO 5 & 41 & 23 & 11 & -- & 18 \\
\hline VWO 6 & -- & 2 & -- & -- & 0 \\
\hline Overig & 8 & 2 & 9 & 12 & 9 \\
\hline Totaal $(\%)$ & 100 & 100 & 100 & 100 & 100 \\
\hline Totaal (abs.) & 143 & 56 & 370 & 34 & 603 \\
\hline
\end{tabular}

Bron: ROA (1989)

Zoals valt te concluderen uit tabel 2.1. heeft bijna de helft van alle benaderde schoolverlaters een afgeronde MAVO-opleiding en bijna een kwart een afgeronde LBO-opleiding als vooropleiding. Bijna een vijfde deel heeft reeds een HAVO-diploma behaald. Tussen de schooltypen zijn er grote verschillen in vooropleiding.

25. Zie ook tabellenboek, tabel 1e.

26. Het betreft hier de opleiding voorafgaand aan de instroming in het (Kort) MBO. Respondenten met een LBO of MAVO als vooropleiding hebben allen het diploma voor deze opleiding behaald (met uitzondering van één respondent van het MMO). Zie ook tabellenboek, tabel $1 \mathrm{f}$.

27. Van het KMBO is alleen van de respondenten van de eerste meting i.p.v. alle benaderde schoolverlaters de vooropleiding bekend, aangezien het KMBO zelf deze informatie niet kon verstrekken en bij de tweede meting is verzuimd dit aan de respondenten te vragen. De respondenten van de eerste meting hebben op een afzonderlijk inlegvel hun vooropleiding vermeld. 
MTS-ers hebben voor ruim een kwart een afgeronde LBO-opleiding genoten. Bij de MEAO-ers en MMO-ers ligt dit percentage veel lager. Daarentegen heeft maar 1 iefst $43 \%$ van de MEAO-ers en $32 \%$ van de MMO-ers een HAVO-opleiding of hoger genoten. Bij de MTS-ers ligt dit percentage slechts op $15 \%$. Van alle respondenten van het KMBO komt bijna tweederde van het LBO en een vijfde deel van het MAVO. Het is opvallend dat alle KMBO-ers die aan de enquête hebben deelgenomen, hun vooropleiding gediplomeerd hebben verlaten.

\section{Leeftijd}

Tabel 2.2. Geboortejaar, per schooltype, in procenten

\begin{tabular}{lccccc}
\hline GEBOORTEJAAR & MEAO & MMO & MTS & KMBO & \multicolumn{2}{c}{ TOTAAL } \\
& $\%$ & $\%$ & $\%$ & $\%$ & $\%$ \\
\hline 1964 en eerder & 1 & 2 & 14 & -- & 33 \\
1965 en 1966 & 29 & 23 & 39 & 57 & 51 \\
1967 en 1968 & 55 & 66 & 46 & 36 & 8 \\
1969 en later & 15 & 9 & 100 & 53 & 100 \\
\hline Totaal (\%) & 100 & 100 & 368 & & 620 \\
Totaal (abs.) & 143 & 56 & & & \\
\hline
\end{tabular}

Bron: ROA (1989)

Uit tabel 2.2. blijkt, dat de helft van de respondenten in 1967 of 1968 is geboren en dus één- of tweeëntwintig jaar is. In 1965 of 1966 is één op de drie respondenten geboren. Bij het analyseren van de verschillen tussen de schooltypen valt op, dat de MTS-ers ouder zijn, dan de respondenten van de overige schooltypen. De KMBO-ers zijn daarentegen jonger. Ruim een derde van deze groep wordt zelfs dit jaar pas twintig!28 Deze verschillen in leeftijd is voor een groot gedeelte te verklaren door de verschillen in cursusduur van de onderscheiden opleidingen.

\section{Opleiding ouders}

Er is, als indicator voor de achtergrond van de schoolverlaters, niet alleen gekeken naar de vooropleiding van de schoolverlaters zelf, maar ook naar

28. Zie ook tabellenboek, tabel $1 d$. 
het regulier onderwijs dat de ouders hebben genoten.29 De tabellen 2.3. en 2.4. geven hierin inzicht.

Tabel 2.3. Opleiding moeder van schoolverlater, per schooltype, in procenten

\begin{tabular}{lccccc}
\hline OPLEIDING MOEDER & MEAO & MMO & MTS & KMBO & TOTAAL \\
& $\%$ & $\%$ & $\%$ & $\%$ & $\%$ \\
\hline LAGER ONDERWIJS & 36 & 28 & 37 & 39 & 36 \\
MULO, ULO, MAVO & 26 & 24 & 27 & 23 & 26 \\
LBO & 26 & 28 & 26 & 30 & 26 \\
MMS, HBS, GYMNASIUM & 5 & 4 & 5 & 2 & 4 \\
MBO & 5 & 14 & 3 & 2 & 5 \\
HBO, WO, OVERIG & 3 & 2 & 2 & 5 & 3 \\
& & & & & \\
\hline Totaal (\%) & 100 & 100 & 100 & 44 & 560 \\
Totaal (abs.) & 132 & 50 & 339 & & \\
\end{tabular}

Bron: ROA (1989)

Tabel 2.4. Opleiding vader van schoolverlater, per schooltype, in procenten

\begin{tabular}{lccccc}
\hline OPLEIDING VADER & MEAO & MMO & MTS & KMBO & TOTAAL \\
& $\%$ & $\%$ & $\%$ & $\%$ & $\%$ \\
\hline LAGER ONDERWIJS & 20 & 20 & 23 & 30 & 23 \\
MULO, ULO, MAVO & 29 & 20 & 17 & 17 & 20 \\
LBO & 19 & 22 & 30 & 30 & 27 \\
MMS, HBS, GYMNASIUM & 11 & 12 & 6 & 9 & 8 \\
MBO & 12 & 20 & 14 & 9 & 14 \\
HBO, WO, OVERIG & 10 & 8 & 10 & 4 & 9 \\
& & & & & \\
\hline Totaal (\%) & 100 & 100 & 100 & 400 & 100 \\
Totaal (abs.) & 132 & 51 & 349 & & 578 \\
\end{tabular}

Bron: ROA (1989)

29. Alleen het reguliere onderwijs is hierbij betrokken. Aanvullende bedrijfs- of brancheopleidingen zijn dus buiten beschouwing gelaten. 
Gemiddeld hebben de moeders een lagere opleiding genoten, dan de vaders van de respondenten. Nog geen derde deel van de vaders en slechts een tiende deel van de moeders heeft een opleidingsniveau hoger dan LBO of (M)ULO. Tussen de verschillende schooltypen, blijken er met name verschillen tussen de opleidingen van de vaders te bestaan. De vaders, wiens kinderen (zonen) het KMBO of MTS hebben gevolgd, zijn relatief laag opgeleid. 30 Schoolverlaters van het MEAO en MMO hebben ouders (vaders) die gemiddeld vaker een hogere en/of algemeen voortgezette opleiding hebben genoten. Daarnaast blijken zowel de moeders als de vaders van MMO-ers relatief goed vertegenwoordigd te zijn in de opleidingscategorie MBO.

Uit het feit dat de helft van de ouders van MMO-ers een beroep of opleiding in dezelfde richting heeft als het kind kan inderdaad worden afgeleid, dat een groot aantal MMO-ers ouders heeft in de (detail)handel. Bij bijna één op de drie kinderen met een KMBO-opleiding heeft één van de vaders eveneens een beroep (of opleiding) in de metaal. Ouders van zowel MTS-ers, als MEAO-ers hebben daarentegen maar in $20 \%$ van de gevallen een beroep of opleiding dat, qua richting, overeenkomt met de door het kind gevolgde richting aan de (Kort) MBO-opleiding. 31

Wanneer wordt gekeken welke ouder een corresponderend beroep of opleiding heeft met de richting van de door het kind gevolgde (Kort) MBO-opleiding, valt direct op dat in ruim $80 \%$ van de gevallen de vader dit corresponderende beroep (of deze opleiding) heeft. 32 Deels is dit terug te voeren op het grotere aandeel van mannen in deze schoolverlatersenquête. Echter bij de MMO-ers zijn het in $63 \%$ van de gevallen juist de beide ouders met dit corresponderende beroep (of deze opleiding). Dit gegeven makkt het nog waarschijnlijker dat veel MMO-ers ouders hebben die (beiden) een zaak in de (detail)handel beheren.

Concluderend kan worden opgemerkt dat zowel het niveau als de richting van de opleiding of het beroep van met name de vaders, bij de keuze van hun kinderen voor een bepaalde opleidingsrichting aan het (Kort) MBO, nogal eens richtinggevend is geweest.

30. Zie ook tabellenboek, tabel $1 \mathrm{j}$ en $1 \mathrm{k}$.

31. Zie ook tabellenboek, tabel 11 .

32. Zie ook tabellenboek, tabel $1 w$. 


\subsection{De keuze van de opleidingsrichting aan het (Kort) MBO}

Laten we eerst eens bekijken welke motieven 33 de schoolverlaters noemen met betrekking tot de keuze van de door hen gevolgde opleidingsrichting binnen een bepaald schooltype aan het (Kort) MBO. Hiervoor kan tabel 2.5. geraadpleegd worden.

Tabel 2.5. Motieven voor de keuze van de opleidingsrichting, per schooltype, in procenten

\begin{tabular}{|c|c|c|c|c|c|}
\hline \multirow[t]{2}{*}{ MOTIEVEN } & MEAO & MMO & MTS & KMBO & TOTAAL \\
\hline & $\%$ & $\%$ & $\%$ & $\%$ & $\%$ \\
\hline graag in deze richting werken & 56 & 59 & 59 & 67 & 59 \\
\hline vakken richting spraken aan & 46 & 48 & 38 & 19 & 39 \\
\hline grote kansen op werk & 27 & 13 & 40 & 42 & 35 \\
\hline aansluiting vakken vooropleiding & 17 & 18 & 15 & 2 & 15 \\
\hline advies familie, kennissen, vrienden & 8 & 16 & 12 & 2 & 11 \\
\hline advies voorafgaande school & 8 & 11 & 5 & 14 & 7 \\
\hline vrienden kozen ook deze richting & 1 & -- & 3 & 6 & 2 \\
\hline vooruitzicht op een hoog inkomen & 1 & 2 & 2 & 4 & 2 \\
\hline advies arbeidsburo e.d. & -- & -- & 1 & -- & 1 \\
\hline een ander motief & 19 & 16 & 10 & 14 & 13 \\
\hline Totaal (abs.) & 143 & 56 & 370 & 52 & 621 \\
\hline
\end{tabular}

Bron: ROA (1989)

Bijna $60 \%$ van de respondenten noemt het feit, dat men "graag in deze richting aan het werk" wil. Bijna $40 \%$ van de respondenten geeft aan dat de "vakken in deze richting aanspreken". "Grote kansen op werk" noemt ruim een derde dee 1 . Een $15 \%$ vindt dat de "vakken goed bij het vakkenpakket van de voorafgaande opleiding passen". "Advies van familie, kennissen of vrienden" of "van de voorafgaande school" werd respectievelijk door $11 \%$ en $7 \%$ gemeld. "Advies van het arbeidsbureau, "het vooruitzicht op een hoog inkomen" of het feit dat "vrienden ook deze richting kozen" spelen nagenoeg geen rol. Wel geeft ruim één op de tien respondenten nog een ander motief op.

33. De respondenten konden hierbij uit 10 motieven de voor hen belangrijkste twee motieven kiezen, zodat de som van de percentages van de afzonderlijke motieven meer dan $100 \%$ bedraagt. 
Tussen de schooltypen zijn er wat dit betreft weinig verschillen. De MTS-ers en met name KMBO-ers leggen wel iets meer nadruk op de arbeidsmarktperspectieven van de gekozen richting, terwijl de MEAO-ers en de MMO-ers vaker de inhoudelijke kant van de richting als motief voor hun keuze noemen. De MMOers en de MTS-ers laten zich meer gelegen liggen aan adviezen van familie, kennissen of vrienden. Dit duidt bij de MMO-ers, gegeven de bevindingen bij de achtergrondkenmerken, mogelijk op het (op termijn) overnemen van de zaak van de ouders. Een kleine 15\% van de KMBO-ers heeft de keuze voor de richting metaaltechnieken mede gebaseerd op het advies van de voorafgaande school. Tenslotte noemt ongeveer één op de zes MEAO-ers en MMO-ers een andere reden voor het kiezen van de gevolgde (Kort) MBO-opleiding. In ruim de helft van de gevallen wordt hier de goede aansluiting met de HEAO genoemd. Gezien de vele MEAO-ers en MMO-ers die een afgeronde HAVO als vooropleiding hebben, blijken de MEAO en MMO nogal eens opstap te vormen voor het HEAO. Dit geldt ook, doch in veel geringere mate, voor het traject HAVO-MTS-HTS. Opvallende "andere motieven" waren verder nog "het kunnen behalen van het middenstandsdiploma" voor de MMO-ers en "het niet kunnen of mogen kiezen van een bepaalde richting" voor KMBO-ers en "ik wist niets anders" voor een aantal MTS-ers. 34

Hoewel er tussen de verschillende opleidingsrichtingen binnen de schooltypen wel verschillen zijn in de motieven voor hun keuze, zijn de aantallen te klein om daar conclusies aan te verbinden. $35 \mathrm{Er}$ bleken overigens tussen de twee examenjaren geen noemenswaardige verschillen te bestaan in de motieven bij de keuze van de opleidingsrichting. 36

Wanneer de verschillen tussen mannen en vrouwen worden bekeken ten aanzien van de motieven, waarom men de gevolgde (Kort) MBO-opleiding heeft gekozen, hebben mannen vaker arbeidsmarktperspectieven laten meewegen en vrouwen vaker vakinhoudelijke aspecten in hun keuze laten prevaleren. Mannen hebben zich bij hun keuze ook meer aangetrokken van het advies van familie, kennissen of vrienden, terwijl vrouwen vaker het advies van de voorafgaande school hebben opgevolgd. 37

34. Zie ook tabellenboek, tabel 10a.

35. Zie ook tabellenboek, tabel 10c.

36. Zie ook tabellenboek, tabel 10b.

37. Zie ook tabellenboek, tabel 10d. 
Het is natuurlijk interessant om te weten of er enig verband bestaat tussen de motieven voor het kiezen van een bepaalde opleidingsrichting aan het (Kort) MBO en de positie die men nu inneemt op de arbeidsmarkt. Dit verband is inderdaad aanwezig (zie ook subparagraaf 3.1.2.). De respondenten die nu dagonderwijs volgen hebben bij de keuze voor de richting aan het (Kort) MBO veel vaker vakinhoudelijke motieven genoemd dan de andere schoolverlaters. Omgekeerd noemen betaald werkenden, al of niet werkend in het kader van het leerlingwezen het "graag in deze richting werken" veel frequenter dan de schoolverlaters die momenteel vervolgopleidingen in het dagonderwijs volgen.

Figuur 2.11. Percentage schoolverlaters bij wie de kans op werk van invloed is geweest op de keuze van de opleidingsrichting, per schooltype

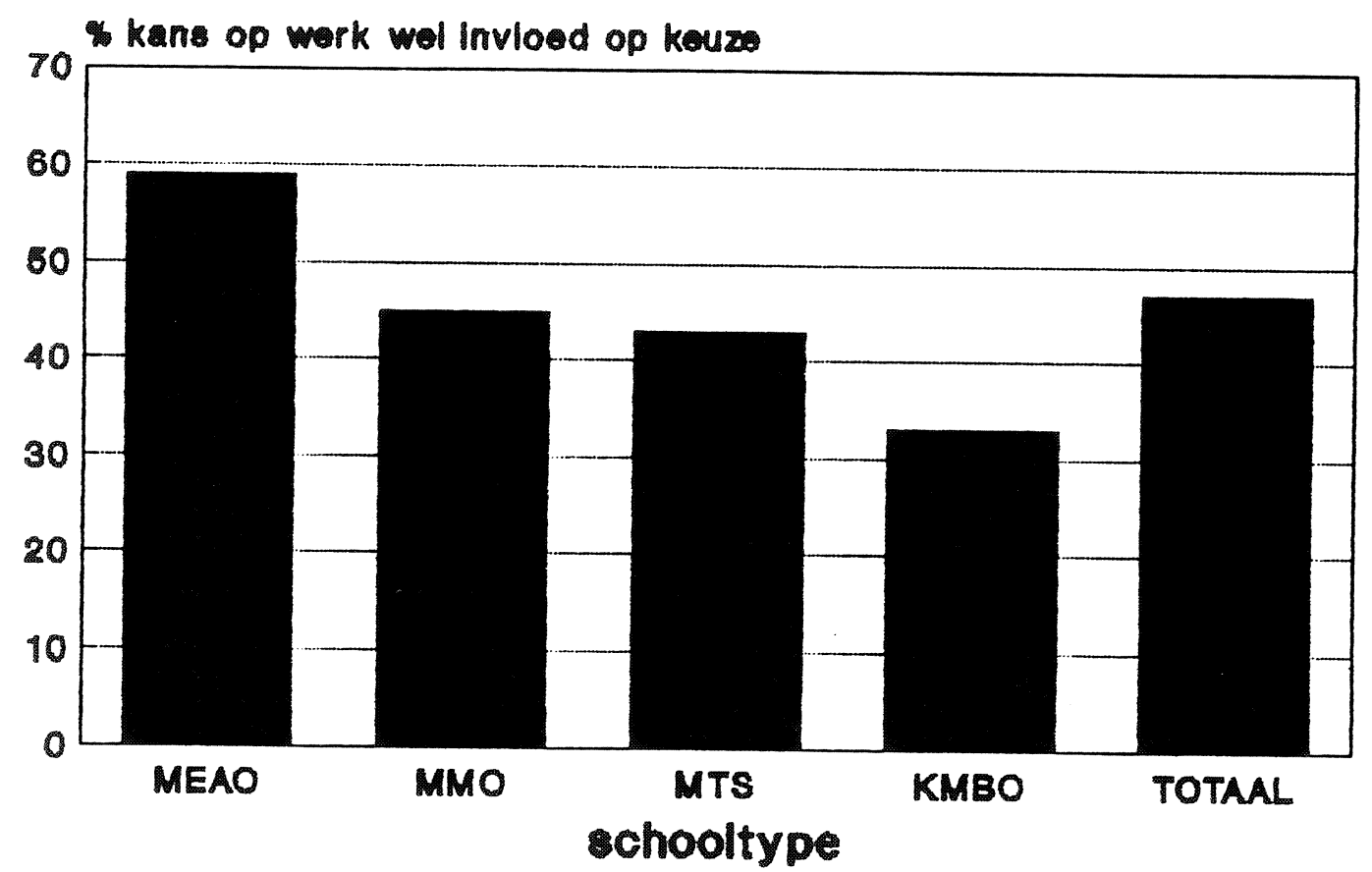

Bron: ROA (1989)

Aan de schoolverlaters is ook direct gevraagd of bij hun keuze van de opleidingsrichting de toekomstige kans op werk van invloed is geweest. Het is opvallend dat nog niet de helft van de respondenten een bevestigend antwoord op deze vraag geeft, zoals bijjkt uit figuur 2.II. De percentages lopen daarbij uiteen van $33 \%$ voor het KMBO, respectievelijk $43 \%$ en $45 \%$ voor de MTS en het MMO tot 59\% voor het MEAO. Blijkbaar heeft de toekomstige kans op werk vooral bij de MEAO-ers een rol gespeeld bij de keuze van hun opleidingsrichting, al wordt het ook door hen niet als één van de belangrijkste overwegingen bij de motieven genoemd. 38

38. Deze conclusie kan men trekken, wanneer men deze resultaten vergelijkt met die van de vraag over de belangrijkste twee motieven bij de keuze van de opleidingsrichting aan het (K)MBO. Zie ook tabellenboek, tabel $1 \mathrm{~h}$. 
Bijna $60 \%$ van de groep KMBO-ers, die aangeven dat de kans op werk een rol heeft gespeeld bij de keuze van de opleidingsrichting, zegt dat de voorlichting over de arbeidsmarkt, die hen aan het (Kort) MBO is aangeboden van invloed is geweest op hun keuze. Circa $43 \%$ van de arbeidsmarktgerichte schoolverlaters van zowel de MTS, als het MMO is dezelfde mening toegedaan. Bij de MEAO-ers is dit percentage slechts $36 \% .39$

Tabel 2.6. verschaft informatie over de vraag, aan welke soort voorlichting over de arbeidsmarkt, die aan het (Kort) MBO is aangeboden, de schoolverlater bij de keuze van de opleidingsrichting het meeste heeft gehad? 40 "Informatie van docenten" wordt het meeste genoemd. Bij het MEAO en MMO door drie-kwart, bij de MTS door tweederde en bij het KMBO door de helft van de respondenten. Juist omdat velen op dit punt waarde blijken te hechten aan de opmerkingen van docenten, is het van groot belang dat de docenten zélf goed op de hoogte zijn én blijven van de ontwikkelingen in hun vakge-bied in het algemeen en het arbeidsmarktperspectief van hun vak in het bijzonder.

Tabel 2.6. Belang van voorlichtingsbronnen over de arbeidsmarkt, per schooltype, in procenten

\begin{tabular}{|c|c|c|c|c|c|}
\hline VOORLICHT INGSBRONNEN & $\begin{array}{c}\text { MEAO } \\
\% \\
\end{array}$ & $\begin{array}{c}\text { MMO } \\
\%\end{array}$ & $\begin{array}{c}\text { MTS } \\
\%\end{array}$ & $\begin{array}{c}\text { KMBO } \\
\% \\
\end{array}$ & $\begin{array}{c}\text { TOTAAL } \\
\% \\
\end{array}$ \\
\hline informatie van docenten & 77 & 73 & 67 & 50 & 69 \\
\hline excursies naar bedrijven & 10 & -- & 34 & 40 & 25 \\
\hline informatie van oud-leerlingen & 20 & 27 & 16 & -- & 17 \\
\hline banenmarkt & 13 & 27 & 6 & -- & 9 \\
\hline film, dia, video & 3 & 9 & 9 & 10 & 8 \\
\hline gastles werkgever, arbeidsbureau & 13 & -- & 5 & 10 & 7 \\
\hline poster, folder & 7 & 18 & 5 & -- & 6 \\
\hline een andere voorlichtingsbron & 10 & 18 & 15 & 40 & 16 \\
\hline Totaal (abs.) & 30 & 11 & 67 & 10 & 118 \\
\hline
\end{tabular}

Bron: ROA (1989)

39. Zie ook tabellenboek, tabel $1 i$.

40. Dit is eveneens een vraag waarbij de schoolverlaters meerdere antwoorden konden aankruisen, zodat de som van de percentages van de afzonderlijke voorlichtingsbronnen meer dan $100 \%$ is. Zie ook tabellenboek, tabel 11a. 
"Informatie van oud-leerlingen" vormt voor een kwart van de MEAO-ers en MMOers een belangrijke aanvulling op de voorlichting door docenten. "Excursies naar bedrijven" scoren daarentegen als voorlichtingsbron bij de KMBO-ers en de MTS-ers erg hoog. Ruim éénderde van de schoolverlaters van deze technische opleidingen heeft dit belangrijk gevonden. Een vierde van de MMO-ers zegt dat een banenmarkt en $18 \%$ dat een poster of folder van belang is geweest bij de keuze van de opleidingsrichting. Bijna de helft van de KMBOers en enkele MTS-ers noemen de stage(s) als voorlichtingsbron.

Wanneer wordt gekeken naar het verband tussen de soort voorlichting en het jaar van afstuderen, blijkt dat de schoolverlaters uit het examenjaar 1987 in ruim drie kwart van de gevallen informatie van docenten noemen, terwijl nog geen $60 \%$ van de schoolverlaters uit 1988 deze voorlichtingsbron noemt. Bovendien is voor deze laatste groep respondenten de spreiding over de antwoorden aanzienlijker groter, wat er kennelijk op wijst, dat voor hen meer voorlichtingsbronnen ter beschikking stonden. 41

Mannelijke schoolverlaters blijken aanzienlijk meer waarde te hechten aan informatie van oud-leerlingen en excursies naar bedrijven, dan vrouwelijke schoolverlaters. Daarentegen hebben banenmarkten, gastlessen door werkgevers of het arbeidsbureau, alsmede audiovisueel materiaal als voorlichtingsbronnen bij de keuze voor de opleidingsrichting op vrouwen beduidend meer indruk gemaakt. De nieuwe vormen van voorlichting lijken dus met name bij het vrouwelijk deel van de respondenten aan te slaan. 42 Deze verschillen tussen mannen en vrouwen vallen hier overigens sterk samen met de schooltypen, waar mannen en vrouwen vertegenwoordigd zijn. Uit deze gegevens is niet te herleiden of hierbij het schooltype dan wel het geslacht de causale factor is.

Er blijken hierbij overigens duidelijke verbanden te bestaan tussen de soort voorlichting die schoolverlaters noemen en de gevolgde vooropleiding. Zoals gezegd, gaat het hier om voorlichtingsbronnen die de schoolverlaters tijdens hun (Kort) MBO-periode is aangeboden. Zo loopt het percentage voor de voorlichtingsbron "informatie van docenten" gestaag op met de vooropleiding: van nog geen $50 \%$ voor schoolverlaters met $L B 0$, via bijna $70 \%$ voor respondenten met MAVO, tot ruim $90 \%$ voor diegenen die een HAVO of hogere onderwijsvorm als vooropleiding hebben.

41. Zie ook tabellenboek, tabel $11 b$.

42. Zie ook tabellenboek, tabel $11 d$. 
Omgekeerd noemt één op de drie schoolverlaters met een LBO-vooropleiding "excursies naar bedrijven" als voorlichtingsbron die bij de keuze van de gevolgde opleidingsrichting aan het (Kort) MBO van belang is geweest. Met het stijgen van het niveau van de vooropleiding, daalt dit percentage voortdurend. Nog geen $5 \%$ van de respondenten met een HAVO-vooropleiding noemt deze voorlichtingsbron. 43 Een verklaringsgrond is wellicht dat de respondenten met een LBO-vooropleiding, welke beroepsgerichter is, meer openstaan voor informatie via bedrijfsexcursies. Bovendien is er, zoals hiervoor reeds werd opgemerkt, ook sprake van een relatie tussen de vooropleiding en de gevolgde (Kort) MBO-opleiding.

43. Zie ook tabellenboek, tabel 11e. 


\section{DE ARBEIDSMARKTPOSITIE VAN DE SCHOOLVERLATERS}

In dit hoofdstuk wordt de arbeidsmarktpositie van de schoolverlaters behandeld. Eerst passeren in paragraaf 3.1. de activiteiten van de schoolverlaters in de periode na het verlaten van het (Kort) MBO de revue, evenals hun huidige economische situatie. Nadat in paragraaf 3.2 . is ingegaan op de positie van de schoolverlaters zonder betaald werk, wordt in paragraaf 3.3 . de arbeidsmarktpositie van de betaald werkenden besproken. In deze paragraaf worden een groot aantal aspecten van het betaalde werk van deze schoolverlaters belicht: arbeidsvoorwaarden en arbeidsmarktflexibiliteit, beroepen, bedrijfssectoren, regionale spreiding, geografische mobiliteit, inkomen en functie-kenmerken.

\subsection{Toetreding tot de arbeidsmarkt}

\subsubsection{Activititeiten na het__(Kort) MBD}

Aan de hand van een tijdschema konden de respondenten voor iedere maand na het verlaten van het (Kort) MBO hun belangrijkste dagelijkse bezigheid aangeven. Voor de schoolverlaters uit het examenjaar 1987 gaat het om de periode mei 1987 tot en met december 1988; voor de schoolverlaters uit het examenjaar 1988 om de maanden mej 1988 tot en met december 1988.

Voor ieder examenjaar hanteren we enkele peildata bij het analyseren van de bezigheden van de respondenten. Voor het examenjaar 1987 zijn dat de volgende peildata:

- mei 1987 (direct na het verlaten van de school);

- oktober 1987 (circa 6 maanden na het verlaten van de school);

- december 1987 (circa 8 maanden na het verlaten van de school);

- mei 1988 (circa 1 jaar na het verlaten van de school);

- oktober 1988 (circa 1,5 jaar na het verlaten van de school);

- december 1988 (circa 20 maanden na het verlaten van de school).

Voor het examenjaar 1988 zijn als peildata gekozen:

- mei 1988 (direct na het verlaten van de school);

- oktober 1988 (circa 6 maanden na het verlaten van de school);

- december 1988 (circa 8 maanden na het verlaten van de school). 
De eerste peildatum is gekozen om te achterhalen hoeveel respondenten direct bij het verlaten van de opleiding reeds een (full-time) betaalde baan hebben. Bovendien kan hierdoor worden nagegaan of schoolverlaters reeds voor het behalen van het diploma actief naar werk zijn gaan zoeken. De tweede peildatum is zó gekozen, dat het dagonderwijs weer begonnen is, zodat minder "ruis" door vakanties kan optreden. Bovendien wordt nog weleens beweerd dat een grote groep schoolverlaters na allerlei omzwervingen op de arbeidsmarkt eerst na ongeveer een half jaar een passende functie vinden. De derde peildatum is met name op praktische gronden opgenomen. Dit betreft namelijk de laatste maand uit het tijdschema voor de schoolverlaters uit het examenjaar 1988. De laatste drie peildata, die alleen betrekking hebben op de bezigheden van schoolverlaters, die in 1987 zijn afgestudeerd, vormen een herhaling van de drie eerste peildata na één jaar.

De gegevens over de peildata worden vanuit twee invalshoeken belicht. Voor ieder examenjaar worden enerzijds de verschuivingen in de economische bezigheden tussen de peildata voor de verschillende schooltypen geregistreerd. Anderzijds wordt bekeken of er tussen de examenjaren wijzigingen zijn opgetreden in de economische situatie op vergelijkbare peildata. 44

Uit tabel 3.1.45 blijkt, dat de helft van de schoolverlaters uit het examenjaar 1987 medio mei 1987 nog bezig is met het afronden van de (Kort) MBO-opleiding. Eén op de vier schoolverlaters heeft in deze maand echter reeds betaald werk, één op de tien respondenten viert daarentegen vakantie, een zelfde deel is werkloos en slechts enkelen vervullen direct hun dienstplicht. In oktober 1987 is dit plaatje drastisch verschoven. De vakantie is voorbij. De helft van de schoolverlaters uit 1987 blijkt werk gevonden te hebben, een derde deel heeft voor een vervolgopleiding gekozen. Zo'n $7 \%$ is werkloos en $9 \%$ zit in (militaire) dienst. Gedurende de daaropvolgende maanden blijkt er een verdergaande verschuiving op te treden naar de categorie dienstplichtigen. Aan het einde van 1988 blijkt weer bijna de helft van deze respondenten betaalde arbeid te verrichten en is nog slechts $16 \%$ bezig met het vervullen van de dienstplicht. Eén op de drie respondenten zit in het vervolgonderwijs, terwijl slechts enkelen werkloos zijn.

44. Zie ook tabellenboek, tabel $25 \mathrm{a} t / \mathrm{m} 25 \mathrm{f}, 250 \mathrm{t} / \mathrm{m} 25 \mathrm{q}$.

45. In de tabel is de categorie "vakantie" toegevoegd aan de categorie "werkloos". Van de schoolverlaters uit de examenjaren 1987 en 1988 gaf respectievelijk $10 \%$ en $13 \%$ voor de maand mei, direct na het verlaten van de (Kort) MBO-opleiding, aan dat zij vakantie hadden. Bij de overige peildata is "vakantie" niet door de schoolverlaters genoteerd. 
Tabe1 3.1. Activiteiten op verscheidene peildata, per examenjaar, in procenten

\begin{tabular}{|c|c|c|c|c|c|c|c|c|}
\hline \multirow{2}{*}{$\begin{array}{l}\text { EXAMENJAAR } \\
\text { ACTIVITEITEN }\end{array}$} & \multicolumn{4}{|c|}{ EXAMENJAAR 1987} & \multicolumn{4}{|c|}{ EXAMENJAAR 1988} \\
\hline & Werk & Werkloos & Onderwijs & Dienst & Werk & Werkloos & Onderwijs & Dienst \\
\hline PEILDATA & $\%$ & $\%$ & $\%$ & $\%$ & $\%$ & $\%$ & $\%$ & $\%$ \\
\hline 1987 mei & 25 & 22 & 51 & 2 & & & & \\
\hline oktober & 51 & 7 & 33 & 9 & & & & \\
\hline december & 51 & 6 & 32 & 12 & & & & \\
\hline 1988 mei & 45 & 2 & 30 & 23 & 29 & 22 & 47 & 2 \\
\hline oktober & 46 & 2 & 32 & 20 & 42 & 5 & 41 & 12 \\
\hline december & 49 & 2 & 33 & 16 & 41 & 5 & 40 & 15 \\
\hline
\end{tabular}

Bron: ROA (1989)

Bij de schoolverlaters uit het examenjaar 1988 is het beeld grotendeels hetzelfde. Uiteraard alleen voor de eerste drie peildata. Toch zijn is er ook enkele verschilpunten. Een half jaar na het verlaten van de (Kort) MBOopleiding blijkt een lager percentage betaalde arbeid te verrichten dan bij de schoolverlaters uit 1987 (51\% versus 42\%). Daarentegen hebben meer schoolverlaters uit het examenjaar 1988 gekozen voor een vervolgopleiding (33\% versus $41 \%)$.

Welke bezigheden zijn nu het belangrijkste op het niveau van de afzonderlijke schooltypen? We nemen daarvoor de peildatum die betrekking heeft op de maand waarin de respondenten circa een half jaar hun (Kort) MBO-opleiding hebben verlaten. Zoals gezegd blijkt dat doorgaans omstreeks deze tijd duidelijk wordt welke keuzen de schoolverlaters hebben gemaakt.46 Tabel 3.2. geeft hierover meer informatie.

Wanneer de gegevens op het niveau van schooltype worden bekeken, dan blijkt de eerder genoemde verschuiving tussen de twee examenjaren van betaald werk naar vervolgonderwijs met name het MEAO en het MMO te betreffen. Terwijl van de MEAO-ers en MMO-ers uit het examenjaar 1987 circa $60 \%$ na een half jaar betaalde arbeid verrichtte, blijkt dit voor de overeenkomstige groep van het

46. Zie ook tabellenboek, tabel 25c, 25p. 
examenjaar 1988 nog maar voor $35 \%$ te gelden. 47 Van de schoolverlaters uit het examenjaar 1988 is bijna de helft van de MTS-ers, MEAO-ers en MMO-ers dagonderwijs gaan volgen. Voor het MEAO en het MMO betekent dit een opvallende toename ten opzichte van 1987.

KMBO-ers kiezen daarentegen met name voor betaald werk. 48 Driekwart van hen heeft een betaalde baan, waarvan $17 \%$ in combinatie met een opleiding in het leerlingwezen. Slechts $16 \%$ van de KMBO-ers volgt een vervolgopleiding in het dagonderwijs. Toch is ook bij de uitstroom van het KMBO een verschuiving richting dagonderwijs waar te nemen. Tenslotte valt op dat vooral bij het MEAO de werkloosheid het laatste jaar fors is gedaald. 49

Tabel 3.2. Activiteiten nadat (Kort) MBO-opleiding een half jaar verlaten is, per schooltype, gedifferentieerd naar examenjaar, in procenten

\begin{tabular}{|c|c|c|c|c|c|c|c|c|}
\hline \multirow{2}{*}{$\begin{array}{l}\text { SCHOOLTYPE } \\
\text { EXAMENJAAR }\end{array}$} & \multicolumn{2}{|c|}{ MEAO } & \multicolumn{2}{|c|}{ MMO } & \multicolumn{2}{|c|}{ MTS } & \multicolumn{2}{|c|}{ KMBO } \\
\hline & '87 & $' 88$ & $' 87$ & ' 88 & ' 87 & $' 88$ & ' 87 & $' 88$ \\
\hline ACTIVITEITEN & $\%$ & $\%$ & $\%$ & $\%$ & $\%$ & $\%$ & $\%$ & $\%$ \\
\hline Betaald werk & 61 & 35 & 58 & 35 & 44 & 40 & 76 & 74 \\
\hline Werkloos & 15 & 6 & 8 & 6 & 5 & 4 & 10 & 6 \\
\hline Dagonderwijs & 18 & 45 & 27 & 52 & 42 & 42 & 5 & 16 \\
\hline Dienstpl icht & 6 & 14 & 8 & 6 & 10 & 14 & 10 & 3 \\
\hline Totaal (\%) & 100 & 100 & 100 & 100 & 100 & 100 & 100 & 100 \\
\hline Totaal (abs.) & 68 & 69 & 26 & 31 & 193 & 175 & 21 & 31 \\
\hline
\end{tabular}

Bron: ROA (1989)

47. Juist de MMO-ers verrichten, in vergelijking met de andere schooltypen, beduidend meer part-time betaalde arbeid. Zo'n $10 \%$ van de schoolverlaters, uit beide examenjaren, hebben een part-time baan.

48. Hierbij dient wel opgemerkt te worden, dat sommige KMBO-ers al langer dan een half jaar van school zijn. Aan het KMBO bestaat immers geen standaard examenperiode aan het einde van het schooljaar.

49. Zoals in paragraaf 1.3. reeds werd opgemerkt, is er hier mogelijk sprake van enige onderschatting van de werkloosheidsomvang als gevolg van een mogelijk grotere non-respons van werkloze schoolverlaters. 


\subsubsection{Huiddige economische situatitie}

Bijna de helft van de schoolverlaters blijkt momentee ${ }^{50}$ betaalde arbeid te verrichten. Dagonderwijs wordt door ruim een derde deel van de respondenten gevolgd en ongeveer $16 \%$ van de schoolverlaters is nog dienstplichtig. Het percentage werklozen variëert van ruim $2 \%$ voor de MTS tot $6 \%$ voor het MEAO.

Tussen de schooltypen zijn een aantal verschillen waar te nemen. Van de drie MBO-schooltypen heeft nog geen $45 \%$ van de oud-leerlingen een betaalde baan en volgt $30-40 \%$ een vervolgopleiding in het dagonderwijs. Bij het KMBO gaan veel meer schoolverlaters direct werken: bijna $70 \%$ (waarvan $17 \%$ in het kader van het leerlingwezen). Daarentegen volgt slechts $14 \%$ van de KMBO-ers dagonderwijs. 51

De verschillen die kunnen worden waargenomen in de huidige situatie tussen de twee examenjaren komen overeen met de verschillen tussen deze twee jaren van afstuderen in de situatie een half jaar na het verlaten van het (Kort) MBO (zie paragraaf 3.1.1.) Een daling aldus van het percentage schoolverlaters dat direct gaat werken (1987: 54\%, 1988: $38 \%$ ), tegenover een toename van de doorstroom naar ander dagonderwijs (1987: 32\%, 1988: 39\%). Bovendien zijn de schoolverlaters uit 1988 , zoals verwacht mag worden, vaker bezig met het vervullen van hun dienstplicht (1987: 11\%, 1988: 20\%). 52

Er blijkt ook een samenhang te bestaan tussen de leeftijd van de schoolverlaters en hun huidige activiteiten. Des te ouder de schoolverlater, des te vaker deze is gaan werken en des te minder vaak deze voor een vervolgopleiding heeft gekozen. Van degenen die in 1962 of daarvoor zijn geboren verricht $100 \%$ betaald werk, van degenen die in 1969 of daarna zijn geboren slechts 39\%. Omgekeerd volgt niemand van de schoolverlaters uit 1962 of eerder (nog) dagonderwijs, terwijl van de jongsten (geboortejaar 1969 of later) maar 1 iefst $49 \%$ vervolgonderwijs heeft gekozen. 53

50. "Momenteel" heeft hier betrekking op het moment van het invullen van de vragenlijst. Dit slaat, met andere woorden, op de periode eind januari tot begin maart 1989 .

51. Zie ook tabellenboek, tabel 1m.

52. Zie ook tabellenboek, tabel 31a.

53. Zie ook tabellenboek, tabel 31b. 
Eveneens blijkt er een verband te bestaan tussen het geslacht en de huidige situatie, waarin de schoolverlaters verkeren. Terwijl van de vrouwen $71 \%$ betaald werk verricht, werkt van de mannen slechts $43 \%$. Enerzijds hangt dit samen met het feit dat vrouwen minder vaak doorleren (28\% versus $36 \%$ ), anderzijds is dit verschil ook het gevolg van de dienstplicht voor mannen. Ruim $17 \%$ van de mannen is daarmee bezig. Aangezien echter een aantal momenteel dienstplichtige mannen, naar eigen zeggen, straks zal gaan kiezen voor een vervolgopleiding, kan toch worden gesteld dat vrouwen na het verlaten van het (Kort) MBO vaker (direct) de arbeidsmarkt betreden en dat mannen, al dan niet na het vervullen van de dienstplicht, verhoudingsgewijs vaker voor een vervolgopleiding kiezen. 54

De vooropleiding (d.w.z. de opleiding die men heeft gevolgd, voordat men is ingestroomd in het (Kort) MBO) blijkt ook een richtinggevende factor bij de huidige situatie te zijn. Zo loopt het percentage schoolverlaters dat betaald werk verricht af van $52 \%$ van de vroegere LBO-ers tot $40 \%$ van de degenen die eerst een HAVO-diploma hebben behaald. Daarentegen loopt het percentage schoolverlaters dat heeft gekozen voor vervolgonderwijs op van $30 \%$ van de vroegere LBO-ers tot $42 \%$ van degenen met HAVO als vooropleiding. 55

Ook het feit dat men aan het $\mathrm{MBO}^{56}$ heeft gedoubleerd, blijkt samen te hangen met de huidige situatie. Terwijl slechts $17 \%$ van de doubleurs een vervolgopleiding is gaan volgen, heeft van degenen, die niet gedoubleerd hebben aan het MBO, $47 \%$ voor een vervolgopleiding in het dagonderwijs gekozen. Doubleurs blijken daarentegen vaker betaald werk te verrichten $(60 \%$ versus $37 \%) .57$

Niet alleen de vooropleiding en de schoolprestaties van de schoolverlaters zélf beïnvloeden de huidige situatie, warin de schoolverlaters verkeren, ook de opleiding van hun ouders is daarop van invloed.

54. Zie ook subparagraaf 3.2.3. en tabellenboek, tabel 31c.

55. Zie ook tabellenboek, tabel 31d.

56. Aan het KMBO kan men niet doubleren, zodat deze schoolverlaters uit deze berekening zijn gelaten.

57. Zie ook tabellenboek, tabel 31e. 
Met het toenemen van het niveau van de opleiding van de ouders 58 neemt het percentage van de kinderen dat betaald werk verricht af en stijgt het percentage van de kinderen dat een vervolgopleiding in het dagonderwijs volgt.

Reeds in subparagraaf 2.2. werd er melding gemaakt van het verband tussen het belang van de kans op werk voor de keuze van de opleidingsrichting en het aantal maanden dat de schoolverlater na het verlaten van het (Kort) MBO heeft gewerkt. Ten aanzien van de huidige situatie bestaat eenzelfde verband. Namelijk van degenen, waarvoor de kans op werk geen rol heeft gespeeld bij de keuze van hun opleidingsrichting, verricht $40 \%$ momenteel betaalde arbeid, terwijl van degenen, die wel rekening hielden met hun arbeidsmarktperspectieven nu 53\% werkt. Omgekeerd volgen degenen, die de kans op werk de keuze van hun opleidingsrichting niet lieten beïnvloeden, vaker vervolgonderwijs ( $43 \%$ versus $27 \%$ ). 59

\subsection{Schoolverlaters zonder betaald werk}

In deze paragraaf wordt achtereenvolgens de situatie van schoolverlaters die dagonderwijs volgen, werkloos of dienstplichtig zijn, nader belicht. Aangezien het onderzoek met name is bedoeld om de aansluiting tussen de (Kort) MBO-opleiding en het betaalde werk te analyseren, is de bespreking hier slechts summier.

In tabel 3.3. kan men aflezen welke vervolgopleidingen de doorlerende schoolverlaters hebben gekozen. Van de MEAO-ers die zijn gaan doorleren, is het overgrote deel ( $86 \%$ ) een opleiding aan het HEAO gaan volgen. Daarentegen heeft van de doorlerenden na het MMO slechts 58\% voor een HEAO-opleiding gekozen. Uiteraard zit het grootste deel van de verder studerende MTS-ers nu op de HTS, zo'n 83\%. Van de KMBO-ers, waarvan zoals gezegd slechts $15 \%$ voor een vervolgopleiding heeft gekozen, doet $43 \%$ een opleiding aan het MBO en een even groot percentage opnieuw een opleiding aan het KMBO.

58. Dit verband geldt zowel voor het opleidingsniveau van de moeder, als dat van de vader. Zie ook tabellenboek, tabellen $31 \mathrm{~g}$ en $31 \mathrm{~h}$.

59. Het is overigens niet zeker of er op dit punt een vertekening optreedt als gevolg van de verschillende belevingswereld waarin de schoolverlaters momenteel verkeren als gevolg van hun verschillende economische situatie, of dat er reeds op het moment van de keuze van hun opleidingsrichting sprake was van een andere oriëntatie. Zie ook tabellenboek, tabel $31 f$. 
3.2.1. Vervolgopleidingen 60

Tabel 3.3. Vervolgopleidingen, per schooltype, in procenten

\begin{tabular}{lccccc}
\hline VERVOLGOPLEIDING & MEAO & MMO & MTS & KMBO & TOTAAL \\
& $\%$ & $\%$ & $\%$ & $\%$ & $\%$ \\
\hline HTS & 7 & 8 & 83 & & 57 \\
HEAO & 86 & 58 & 1 & & 24 \\
MBO & -- & 8 & 11 & 43 & 10 \\
KMBO & -- & -- & -- & 43 & 1 \\
HA061 & -- & 4 & 1 & 14 & 1 \\
Overig62 & 7 & 21 & 4 & -- & 6 \\
& & & & 100 & 100 \\
\hline Totaal (\%) & 100 & 100 & 100 & 7 & 219 \\
Totaal (abs.) & 43 & 24 & 145 & & \\
& & & & & \\
\hline
\end{tabular}

Bron: ROA (1989)

Van enkele clusters van opleidingstypen in het vervolgonderwijs is nagegaan welke richtingen het meest gekozen zijn. Op de HTS heeft ongeveer $40 \%$ electrotechniek gekozen, bijna $20 \%$ werktuigbouwkunde, $10 \%$ (bouw)technische bedrijfskunde en eveneens $10 \%$ chemische (milieu)technologie. Voor een deel zijn de hoge percentages voor electrotechniek en werktuigbouwkunde toe te schrijven aan het feit dat velen reeds aan de MTS één van deze richtingen heeft gekozen. Het hoge percentage voor werktuigbouwkunde aan de HTS kan hierdoor worden verklaard.63 Aan de HEAO volgen de schoolverlaters uit 1988 momenteel nog het algemene jaar. Ook van de schoolverlaters uit 1987 volgt nog $20 \%$ dit propedeutisch jaar. Eveneens $20 \%$ heeft bedrijfseconomie gekozen, de overigen zijn over een tiental HEAO-richtingen verspreid. 64

60. Dit betreft vervolgopleidingen in het dagonderwijs. De positie van de schoolverlaters, die een opleiding in het kader van het leerlingwezen volgen, wordt in paragraaf 3.3. besproken. Deze schoolverlaters werken immers naast hun opleiding. Zie ook tabellenboek, tabel $3 \mathrm{c}$.

61. HAO staat voor hoger agrarisch onderwijs. In deze categorie is ook de opleiding "Landbouwmechanisatie" opgenomen.

62. Overig onderwijs omvat al het hoger sociaal, cultureel, pedagogisch en verzorgend onderwijs.

63. Zie ook tabellenboek, tabel $3 j$.

64. Zie ook tabellenboek, tabel $3 \mathrm{~h}$. 
Tabel 3.4. Motieven voor volgen van vervolgopleidingen, per schooltype, in procenten

\begin{tabular}{|c|c|c|c|c|c|}
\hline MOTIEVEN & $\begin{array}{c}\text { MEAO } \\
\% \\
\end{array}$ & $\begin{array}{c}\text { MMO } \\
\% \\
\end{array}$ & $\begin{array}{c}\text { MTS } \\
\% \\
\end{array}$ & $\begin{array}{c}\text { KMBO } \\
\% \\
\end{array}$ & $\begin{array}{c}\text { TOTAAL } \\
\% \\
\end{array}$ \\
\hline Opleidingsniveau meer loopbaanmogelijkheden & 67 & 46 & 56 & 33 & 57 \\
\hline Inhoud opleiding sprak aan & 21 & 46 & 32 & 33 & 32 \\
\hline Kan hiermee meer gaan verdienen & 19 & 36 & 35 & 33 & 32 \\
\hline Geen zin in werk dat aansluit op (K)MBO & 24 & 14 & 27 & -- & 25 \\
\hline Nog geen zin in werken & 24 & 23 & 22 & 33 & 23 \\
\hline Opleiding biedt grotere kans op werk & 31 & 23 & 15 & 17 & 19 \\
\hline Op advies van anderen & -- & -- & 3 & 33 & 3 \\
\hline Kan geen werk vinden & 2 & -- & -- & -- & 1 \\
\hline Vrienden gingen deze opleiding volgen & -- & -- & -- & -- & -- \\
\hline Een ander motief & -- & 5 & 3 & 17 & 3 \\
\hline Totaal (abs.) & 42 & 22 & 146 & 6 & 216 \\
\hline
\end{tabular}

Bron: ROA (1989)

Arbeidsmarktperspectieven hebben bij de keuze van een vervolgopleiding duidelijk een grotere rol gespeeld, dan bij de keuze van een (Kort) MBO-opleiding (zie tabel 3.4.).65 Ruim de helft van de schoolverlaters noemt als motief dat "het opleidingsniveau meer loopbaanmogelijkheden biedt". Van de MEAO-ers is zelfs tweederde deze mening toegedaan, van de KMBO-ers echter slechts een derde deel. Bijna één op de drie schoolverlaters denkt "straks met deze opleiding meer te verdienen". De MEAO-ers hebben dit overigens slechts in $19 \%$ van de gevallen opgemerkt. Daarentegen noemt wel $31 \%$ van de MEAO-ers het feit dat "dit opleidingsniveau een grotere kans op werk biedt". Een kwart van de MEAO-ers en MTS-ers geeft aan dat "het werk dat aansluit bij hun MBO-opleiding niet voldoende bij hen past". Dit motief wordt minder vaak genoemd door MMO-ers en in het geheel niet door KMBO-ers. Uiteraard "spreekt de inhoud van de opleiding aan". Deze reden wordt door $46 \%$ van de MMO-ers en een derde van de MTS-ers en KMBO-ers genoemd. Daarentegen slechts door $21 \%$ van de MEAO-ers. Van de KMBO-ers geeft $33 \%$ aan de opleiding (mede) op advies van anderen te volgen. Het "niet kunnen vinden van werk" en het feit dat "vrienden deze opleiding gingen volgen" speelt hoegenaamd geen rol.

65. Op deze vraag konden de respondenten meerdere antwoorden geven. Als gevolg hiervan bedraagt de som van de percentages van de afzonderlijke redenen meer dan $100 \%$. Zie ook paragraaf 2.2. en tabellenboek, tabel $14 a$. 
Wanneer deze motieven voor het volgen van een vervolgopleiding worden verdeeld naar geslacht, springen er enkele verschillen uit. Terwijl van de mannen één derde opmerkt dat "met deze opleiding straks meer verdiend kan gaan worden", noemt van de vrouwen slechts een vijfde deel deze reden. Daarentegen zegt ruim de helft van de vrouwelijke schoolverlaters dat de "inhoud van de opleiding aanspreekt", terwijl nog geen $30 \%$ van de mannen dit feit noemt. 66 ook bij het kiezen van een vervolgopleiding laten mannen zich kennelijk vaker leiden door loopbaanperspectieven dan vrouwen.

Hoewel uit de opmerkingen die de schoolverlaters aan het einde van de vragenlijst hebben gemaakt blijkt, dat de aansluiting van het (Kort) MBO naar het vervolgonderwijs op sommige punten verbeterd zou kunnen worden, verwacht toch $95 \%$ van de doorlerenden dat zij hun vervolgopleiding met succes af zullen ronden. Er bestaan op dit punt slechts marginale verschillen tussen de vier onderzochte schooltypen. 67

\subsubsection{Werkloosheㅁㅁ}

Zoals gezegd, blijkt het aantal respondenten dat ten tijde van de onderzoeksmetingen werkloos is, zo klein te zijn dat het niet relevant is de resultaten in percentages weer te geven. We volstaan derhalve in deze subparagraaf met een beschrijving in absolute aantallen.

Vijftien van de negentien respondenten, die dit vragenblok hebben ingevuld, hebben zich ingeschreven bij het arbeidsbureau. Vijftien respondenten zeggen ook actief naar werk te zoeken. Van deze vijftien hebben er zeven de afgelopen vier weken zeven of meer keer gesolliciteerd. Toch is maar één respondent in deze periode vier of meer keer voor een sollicitatiegesprek uitgenodigd. Acht respondenten hebben in de afgelopen vier weken maximaal drie sollicitatiegesprekken achter de rug en zes personen zijn in deze periode geen enkele keer op gesprek geweest. Dertien van de vijftien personen, die actief naar werk hebben gezocht, zoeken een baan voor 20 of meer uur per week. Zestien van de negentien respondenten zijn binnen twee weken beschikbaar voor de arbeidsmarkt. Eén van de drie personen, die niet beschikbaar zijn voor de arbeidsmarkt, kan niet beginnen wegens ziekte.

66. Zie ook tabellenboek, tabel $14 \mathrm{~d}$.

67. Zie ook tabellenboek, tabel $3 a$ en $3 b$. 
Geen van de werklozen blijkt werkervaring op te doen via een werkervaringsproject. Eén van de werkloze respondenten is wel bezig een eigen bedrijf op te zetten. Deze schoolverlater vindt overigens wel dat het (Kort) MBO meer aandacht had moeten besteden aan het starten en beheren van een eigen zaak.

Een cursus, waarbij in alle gevallen een diploma kan worden behaald, hebben elf van de negentien respondenten na hun opleiding gevolgd. In subparagraaf 4.3.2. zal iets meer worden gezegd over de aard van deze cursussen. Vijftien van de negentien respondenten is bereid een functie buiten Midden-Limburg te aanvaarden (zie ook subparagraaf 3.3.5). Tenslotte noemen tien van de negentien respondenten "te weinig werkervaring" als één van de belangrijkste redenen waarom zij werkloos zijn. Een belangrijke reden voor het werkloos zijn blijkt ook het "wachten op de oproep voor de (militaire) dienst" te zijn. 68

\subsubsection{Dienst미므는}

Bij zo'n 15\% van de schoolverlaters is ten tijde van het onderzoek de school- of beroepsloopbaan onderbroken door de dienstplicht. Veel dienstplichtigen hebben evenwel oog voor hun activiteiten in de toekomst. Ruim één op de drie dienstplichtigen is namelijk na het (Kort) MBO een cursus gaan volgen, waarvoor, op één uitzondering na, een diploma is te behalen. Dit geldt echter in mindere mate voor de dienstplichtige KMBO-ers, waarvan slechts $14 \%$ hierna een cursus heeft gevolgd (zie ook subparagraaf 4.3.2.).69

Bijna alle dienstplichtigen weten al wat zij na hun diensttijd willen gaan doen. Zoals blijkt uit tabel 3.5., wil de helft van de MBO-ers alleen betaalde arbeid verrichten. De dienstplichtig KMBO-ers voelen er echter meer voor na hun dienstplicht te gaan werken in combinatie met een (avond)opleiding. Ruim 43\% van de KMBO-ers kiest namelijk voor deze mogelijkheid, terwijl van de dienstplichtigen afkomstig van het MEAO en de MTS circa $30 \%$ betaald werken wil combineren met een (avond)studie. Dienstplichtige MMO-ers kiezen juist meer voor het volgen van een dagopleiding. 70

68. Zie ook tabellenboek, tabel $2 \mathrm{a} t / \mathrm{m} \mathrm{2p}, 12 \mathrm{a} t / \mathrm{m} 12 \mathrm{~h}, 13 \mathrm{a} t / \mathrm{m} 13 \mathrm{~d}$.

69. Zie ook tabellenboek, tabel $4 \mathrm{a}, 4 \mathrm{~b}, 4 \mathrm{~d} \mathrm{t} / \mathrm{m} 4 \mathrm{~g}$.

70. Zie ook tabellenboek, tabel $4 \mathrm{c}$. 
Tabe1 3.5. Verwachte economische bezigheid na dienstplicht, per schooltype, in procenten

\begin{tabular}{|c|c|c|c|c|c|}
\hline \multirow[t]{2}{*}{ BEZIGHEID } & MEAO & MMO & MTS & KMBO & TOTAAL \\
\hline & $\%$ & $\%$ & $\%$ & $\%$ & $\%$ \\
\hline Betaald werken & 48 & 50 & 52 & 29 & 49 \\
\hline Werken en leren & 35 & -- & 28 & 43 & 29 \\
\hline Vervolgonderwijs & 17 & 33 & 19 & -- & 18 \\
\hline Andere bezigheid & -- & 17 & 2 & 29 & 4 \\
\hline Totaal (\%) & 100 & 100 & 100 & 100 & 100 \\
\hline Totaal (abs.) & 23 & 6 & 58 & 7 & 94 \\
\hline
\end{tabular}

Bron: ROA (1989)

\subsubsection{Werkervaring}

Tenslotte is aan de studerenden, werklozen en dienstplichtigen gevraagd of zij in de periode na het behalen van hun diploma langer dan een half jaar bij één werkgever hebben gewerkt. Voor circa $10 \%$ van deze groep blijkt dat het geval te zijn geweest. Van de KMBO-ers, die momenteel niet werken, heeft maar liefst de helft na het verlaten van de opleiding intussen langer dan een half jaar voor één werkgever gewerkt. Dit is ongetwijfeld het gevolg van het feit dat een deel van de KMBO-ers reeds voor het einde van het schooljaar de opleiding heeft afgerond. Van degenen die momenteel werkloos of dienstplichtig zijn heeft ongeveer een vijfde deel na het (Kort) MBO langer dan een half jaar bij één werkgever gewerkt. Dit geldt slechts voor $3 \%$ van de schoolverlaters die weer dagonderwijs volgen. De militaire dienstplicht is in tweederde van de gevallen de reden, dat men niet meer bij de voorgaande werkgever werkt. Bij ongeveer $20 \%$ was het aflopen van het arbeidscontract de reden hiervoor 71

\subsection{Schoolverlaters met betaald werk}

$\mathrm{Na}$ in voorgaande paragraaf de schoolverlaters die niet werken te hebben besproken, wordt de positie van werkenden op de arbeidsmarkt belicht.

71. Zie ook tabellenboek, tabel 1p, 1q, 1r. 
Zoals eerder werd opgemerkt, heeft bijna de helft van de schoolverlaters een betaalde baan. Van de drie MBO-schooltypen heeft ruim $40 \%$ van de oudleerlingen een betaalde baan. Bij het KMBO ligt dit percentage zoals gezegd veel hoger: 70\%. Dit komt met name doordat KMBO-leerlingen minder doorstromen naar vervolgopleidingen.

\subsubsection{Arbeidsvoorwaarden en arbeidsmarktflexibiliteit}

Aan de hand van een bespreking van een aantal arbeidsvoorwaarden en enkele andere indicatoren wordt inzicht verschaft in de arbeidsmarktflexibiliteit van de schoolverlaters. De volgende variabelen worden hierbij gebruikt:

- de wijze waarop de huidige baan is verkregen;

- het soort dienstverband;

- de aard van de aanstelling;

- de arbeidsduur per week;

- het aantal werkgevers waarbij de werkende schoolverlaters na hun (Kort) MBO-opleiding hebben gewerkt;

- het werken in ploegen- of onregelmatige dienst.

Wijze van functieverwerving

Tabel 3.6. Wijze waarop huidige functie is verkregen, per schooltype, in procenten

\begin{tabular}{lccccc}
\hline WIJZE VAN FUNCTIEVERWERVING & MEAO & MMO & MTS & KMBO & TOTAAL \\
\hline Reactie op vacature & $\%$ & $\%$ & $\%$ & $\%$ & $\%$ \\
Op eigen initiatief, open sollicitatie & 19 & 26 & 30 & 15 & 25 \\
Via stagecontacten of leer-/werkcontract & 10 & 11 & 19 & 12 & 15 \\
Via familie of kennissen & 8 & 16 & 15 & 15 & 14 \\
Via tijdelijk werk (uitzendbureau) & 11 & 5 & 10 & 24 & 12 \\
Via het arbeidsbureau & 14 & 32 & 8 & 12 & 12 \\
Via docenten of decaan van (Kort) MBO & 18 & 11 & 9 & 18 & 12 \\
Op andere wijze & 21 & -- & 8 & 3 & 10 \\
\hline Totaal (\%) & -- & -- & 1 & -- & 1 \\
Totaal (absoluut) & & & 100 & 100 & 100 \\
\hline
\end{tabular}

Bron: ROA (1989) 
De wijze waarop de huidige baan is verkregen verschilt aanzienlijk per schooltype, zoals blijkt uit tabel 3.6. Voor de werkende MEAO-ers zijn het solliciteren op een vacature, de bemiddeling door docenten of decaan aan het MEAO en het arbeidsbureau met ieder ongeveer een vijfde deel de belangrijkste kanalen waarlangs de huidige baan is verkregen. Eénderde van de MMO-ers heeft er baat bij gehad (eerst) tijdelijk werk te accepteren en een kwart heeft de baan gekregen door te solliciteren op een vacature. Bijna één op de drie werkende MTS-ers heeft de huidige baan bemachtigd door te solliciteren op een vacature en $19 \%$ door op eigen initiatief (open) te solliciteren. KMBO-ers blijken vooral van familie of kennissen hulp te hebben gehad bij het vinden van een baan. Bijna een kwart van hen heeft op deze wijze een baan gevonden. Via het arbeidsbureau is $18 \%$ van de werkende KMBO-ers aan de slag gekomen. Vijftien procent van hen heeft werk gevonden via stagecontacten of via het reageren op een vacature. 72

\section{Dienstverband}

Op vijf MTS-ers na zijn alle werkende schoolverlaters in loondienst. Deze vijf MTS-ers zijn allemaal werkzaam als zelfstandige. 73

\section{Aanstelling}

Tabel 3.7. Soort aanstelling, per schooltype, in procenten

\begin{tabular}{lccccc}
\hline SOORT AANSTELLING & MEAO & MMO & MTS & KMBO & TOTAAL \\
& $\%$ & $\%$ & $\%$ & $\%$ & 72 \\
\hline Vaste aanstelling & 72 & 67 & 78 & 11 & 75 \\
Tijdelijke aanstelling & 27 & 25 & 20 & 17 & 21 \\
Leer-/werkcontract & 2 & 8 & 2 & 100 & 100 \\
\hline Totaal (\%) & 100 & 100 & 100 & 36 & 274 \\
Totaal (abs.) & 67 & 24 & 147 & & \\
\end{tabular}

Bron: ROA (1989)

72. Zie ook tabellenboek, tabel $5 i$.

73. Naar de mening van deze vijf respondenten is op de MTS te weinig aandacht besteed aan het opzetten en beheren van een eigen bedrijf. Zie ook tabellenboek, tabel $5 \mathrm{a} \mathrm{t} / \mathrm{m} 5 \mathrm{c}$. 
Zoals valt af te lezen uit tabel 3.7. heeft driekwart van de respondenten een vaste aanstelling, Daarentegen heeft $21 \%$ slechts een tijdelijke aanstelling en $4 \%$ een leer-/werkovereenkomst in het kader van het leerlingwezen. Tussen de vier onderzochte schooltypen kunnen de volgende verschillen worden waargenomen. De MTS-ers hebben met $78 \%$ het meest veelvuldig een vaste aanstelling, gevolgd door het MEAO en KMBO met $72 \%$. Van de MMO-ers heeft tweederde een vaste aanstelling. Eén op de vier MEAO-ers en MMO-ers en één op de vijf MTS-ers heeft een tijdelijke aanstelling. Slechts $11 \%$ van de KMBO-ers heeft daarentegen tijdelijk werk. Het zijn met name de KMBO-ers die een leer-/werkovereenkomst hebben, namelijk $17 \%$ onder hen. 74

De schoolverlaters uit het examenjaar 1988 blijken frequenter een tijdelijke aanstelling te hebben dan de schoolverlaters uit 1987. Van de respondenten die op het moment van onderzoek zo'n driekwart jaar geleden hun opleiding hebben verlaten, heeft (nog) bijna éénderde een tijdelijke aanstelling. Van de schoolverlaters die reeds anderhalf jaar van de opleiding af zijn, werkt daarentegen slechts $13 \%$ (nog) op tijdelijke basis. Ruim $83 \%$ van deze groep heeft een vaste betrekking.

Er bestaat tevens een verband tussen de periode dat de schoolverlaters werkzaam zijn en de aard van de aanstelling. Schoolverlaters met een vaste aanstelling hebben in bijna de helft van de gevallen een werkervaring van meer dan een jaar, bij tijdelijke werkers geldt dat slechts voor nog geen $15 \%$. Omgekeerd is het nog duidelijker; van de werkenden die meer dan een jaar werkervaring hebben, heeft ruim $90 \%$ een vaste baan, de overige $10 \%$ heeft een tijdelijke aanstelling of een leer-/werkovereenkomst. Ruim tweederde van de tijdelijk werkenden heeft hooguit 6 maanden werkervaring. 75

Uit deze cijfers kan worden afgeleid dat mogelijk veel schoolverlaters eerst tijdelijk werk hebben, alvorens zij een vaste baan kunnen bemachtigen. 76 Het is echter ook mogelijk dat de schoolverlaters uit 1987 vaker direct een baan met een vaste aanstelling hebben kunnen bemachtigen dan de schoolverlaters uit 1988.

74. Zie ook tabellenboek, tabel $5 \mathrm{~d}$.

75. Zie ook tabellenboek, tabe 160 .

76. Zie ook tabellenboek, tabel 5e. 
Arbeidsduur

Tabel 3.8. Arbeidsduur per week, per schooltype, in procenten

\begin{tabular}{lccccc}
\hline ARBEIDSDUUR & MEAO & MMO & MTS & KMBO & TOTAAL \\
per week & $\%$ & $\%$ & $\%$ & $\%$ & $\%$ \\
\hline 30 uur of minder & -- & 11 & 2 & 9 & 5 \\
$31-35$ uur & 5 & 11 & 4 & 79 & 86 \\
$36-40$ uur & 91 & 79 & -- & 6 & 6 \\
41 uur of meer & 5 & 100 & 100 & 100 & 100 \\
\hline Totaal (\%) & 100 & 19 & 144 & 33 & 259 \\
Totaal (abs.) & 63 & & & \\
\hline
\end{tabular}

Bron: ROA (1989)

Gemiddeld $86 \%$ van de werkenden heeft een baan met een arbeidsduur tussen de 36 en 40 uur per week (zie tabe1 3.8.). MMO-ers en KMBO-ers hebben minder vaak een dergelijke full-time arbeidsweek. Van deze opleidingen heeft respectievelijk $22 \%$ en $15 \%$ een deeltijdfunctie. Van de MTS-ers en MEAO-ers werkt ongeveer 5\% minder dan 36 uur uur per week. Meer dan 40 uur per week werkt daarentegen $6 \%$ van de schoolverlaters met betaald werk. 77

De groep schoolverlaters die in 1987 examen heeft gedaan, heeft in ruim 90\% van de gevallen een werkweek van 36 tot en met 40 uur. Voor de groep uit 1988 geldt dat in mindere mate, namelijk voor nog geen $80 \%$. Bijna $15 \%$ van deze laatste groep werkt minder dan 36 uur, tegenover slechts $3 \%$ van de schoolverlaters uit 1987.78

Het overgrote deel van de werkende schoolverlaters is tevreden met hun wekelijkse contractuele arbeidsduur. Slechts $5 \%$ is hierover ontevreden. Bij het MMO, waar een relatief hoog percentage een deeltijdfunctie heeft, is daarentegen ruim één op de vijf werkenden niet tevreden over de arbeidsduur. 79 Het merendeel van deze MMO-ers zou graag meer uren per week werken.

77. Zie ook tabellenboek, tabel $5 j$.

78. Zie ook tabellenboek, tabel 5k.

79. Zie ook tabellenboek, tabel $5 x$. 
De meeste MEAO-ers en MTS-ers, die ontevreden zijn over de wekelijkse arbeidsduur, zouden juist liever een kortere werkweek hebben. 80

Ruim twee op de drie werkende schoolverlaters blijkt wel eens over te werken. Voor de MM0-ers geldt dit zelfs in bijna 90\% van de gevallen. Werkende KMBO-ers blijken dit voor driekwart te doen. Van de MTS-ers werkt bijna $70 \%$ over en van de werkenden met een MEAO-opleiding ruim $60 \% .81$

Wanneer het overwerken wordt gecorreleerd aan het inkomen (netto per maand) uit betaald werk is een opvallend patroon waar te nemen. Naarmate het inkomen stijgt, daalt het aantal werkenden dat overwerkt. Van de werkenden met een inkomen van minder dan 1.000 gulden per maand werkt bijna $90 \%$ over. In de inkomenscategorie 1.750 tot 2.000 gulden werkt daarentegen nog maar circa $60 \%$ over. In de twee hoogste inkomenscategorieën neemt het aantal overwerkers weer toe tot ruim driekwart van de werkenden. 82

\section{Aantal werkgevers na (Kort) MBO}

Bijna tweederde van de schoolverlaters heeft na de (Kort) MB0-opleiding slechts één werkgever gehad. Circa één op de drie schoolverlaters heeft reeds bij twee of drie werkgevers gewerkt. Slechts enkelen hebben al vier of meer werkgevers gehad. Tussen de schooltypen bestaan op dit punt wel forse verschillen. Terwijl van de MEAO-ers, MTS-ers en KMBO-ers tussen de $62 \%$ en $73 \%$ tot nu toe slechts één werkgever heeft gehad, heeft van het MMO daarentegen ruim tweederde bij twee of drie werkgevers gewerkt.83 0ok hier blijkt weer dat MMO-ers minder snel een wat vastere bestemming op de arbeidsmarkt vinden dan de schoolverlaters van de andere schooltypen.

Hoewel men zou verwachten dat de schoolverlaters uit het examenjaar 1987 na hun opleiding inmiddels bij meer werkgevers gewerkt zouden hebben, is dit opvallend genoeg niet het geval. Van beide examenjaren heeft circa tweederde bij slechts één en circa éénderde bij twee of drie werkgevers gewerkt. 84

80. Zie ook tabellenboek, tabel $5 z$.

81. Zie ook tabellenboek, tabel 6a.

82. Zie ook tabellenboek, tabel $6 c$.

83. Zie ook tabellenboek, tabel $5 f$.

84. Zie ook tabellenboek, tabel $5 \mathrm{~g}$. 
De schoolverlaters, die in 1988 de opleiding gediplomeerd hebben verlaten, hebben derhalve (relatief) vaker en sneller van werkgever gewisseld. Dit vormt een indicatie voor een toenemende zoekactiviteit op de arbeidsmarkt door de schoolverlaters en mogelijk ook voor de toenemende betekenis van verdringingsprocessen.

\section{Onregelmatige of ploegendienst}

Zo'n $10 \%$ van de werkende schoolverlaters werkt in een onregelmatige of ploegendienst. Van de werkende MEAO-ers draait slechts $3 \%$ een dergelijke dienst. Voor de werkenden met een MTS- of KMBO-opleiding ligt het percentage met respectievelijk $13 \%$ en $15 \%$ iets boven het gemiddelde. 85

Al met al kan worden geconcludeerd dat de arbeidsmarktflexibiliteit van de schoolverlaters op een aantal punten duidelijk aanwezig is. Aanwijzingen hiervoor zijn het aantal tijdelijke functies, vooral van de recent afgestudeerden, de vele wijzen waarop schoolverlaters naar werk zoeken (en vinden!) en het feit dat een aanzienlijke groep schoolverlaters bij meer werkgevers heeft gewerkt. Bovendien werkt een aanzienlijk deel in een onregelmatige dienst en en heeft $6 \%$ van de werkenden een werkweek van meer dan 40 uur. Het aantal schoolverlaters dat in deeltijd werkt is echter niet groot. Bij het MMO is de waargenomen flexibiliteit over het algemeen het grootst. Bij de overige schooltypen overheerst daarentegen het aantal vaste full-time dienstverbanden in hoge mate.

\subsubsection{Beroepen}

Bij het indelen van de door, de schoolverlaters genoteerde, beroepen in relevante categorieën is gebruik gemaakt van de beroepenclassificatie die door het CBS wordt gehanteerd bij enkele sociaal-economische statistieken, waaronder de Enquête beroepsbevolking (E.B.B.). Om de beroepen overzichtelijk te presenteren is voor zowel de economisch-administratieve, als de productie-technische opleidingen een afzonderlijke beroepsindeling gemaakt. Allereerst wordt de beroepenstructuur van de werkende MEAO-ers en MMO-ers besproken, vervolgens van de werkende schoolverlaters van de MTS en het KMBO.

85. Zie ook tabellenboek, tabel 51. 
MEAO en MMO

Tabel 3.9. Beroepen van MEAO-ers en MMO-ers, in procenten

\begin{tabular}{lcc}
\hline BEROEPEN & MEAO & MO \\
\hline Administrateur, (assistent-)boekhouder & $\%$ & 15 \\
Commercieel-administratief medewerker & 34 & 15 \\
Bankemployé & 15 & 10 \\
Verzekeringsemployé & 12 & -- \\
Secretaresse, datatypist & 8 & 5 \\
Andere administratieve functie & 8 & 5 \\
Winkel-, verkoop-, magazijnmedewerker & 10 & 25 \\
Verkoper buitendienst & 7 & 10 \\
(Assistent-)bedrijfsleider & -- & 10 \\
Automatiseringsfunctie & -- & 5 \\
Productiemedewerker (lopende band) & 2 & 20 \\
Andere functie & 2 & -- \\
\hline Totaal (\%) & 31 & -- \\
Totaal (abs.) & 3 & \\
\hline
\end{tabular}

Bron: ROA (1989)

Van de werkende MEAO-ers vervult $34 \%$ een functie als assistent-boekhouder of assistent-accountant; van de werkende MMO-ers heeft slechts $15 \%$ een dergelijke functie (zie tabel 3.9.). Gezien het grote aantal MEAO-ers met een opleiding in de bedrijfsadministratieve richting is dit niet verwonderlijk. Van beide groepen is $15 \%$ werkzaam als commercieel-administratief medewerker. Circa één op de tien werkende MEAO-ers en MMO-ers heeft een baan als bankemployé. Het grootste verschil in de beroepenstructuur tussen de beide schooltypen betreft de beroepsgroepen winkel-, verkoop-en magazijnpersoneel. Een kwart van de werkende MMO-ers behoort tot deze beroepscategorie, terwij 1 van de werkzame MEAO-ers slechts $7 \%$ dit werk verricht. Daarentegen werkt $8 \%$ van de werkende MEAO-ers als verzekeringsemployé, terwijl geen enkele werkende MMO-er een dergelijke functie heeft. Administratieve functies, zoals secretaresse of datatypist, worden bijna twee maal zo vaak vervuld door MEAO-ers als door MMO-ers. Voor het MEAO geldt een percentage van $18 \%$, 
voor het MMO een percentage van $10 \% .86$ Tenslotte heeft $10 \%$ van de MMO-ers een baan als handelsvertegenwoordiger en eveneens $10 \%$ als bedrijfsleider. 87

Op het eerste gezicht lijken de functies aan te sluiten bij de gevolgde opleidingen. Wat betreft de richting van de functies klopt dit zeker. Van de MEAO-ers vervult circa $85 \%$ een functie die qua richting past bij deze opleiding. Bij de MMO-ers is dit slechts bij $60 \%$ het geval. Daarentegen is het niveau van de werkzaamheden die men vervult vaak nogal laag. Werknemers met een administratieve functie (bijna $90 \%$ van de MEAO-ers en $65 \%$ van de MMO-ers) zijn vooral bezig met het invoeren van (standaard)gegevens per computer of het typen van allerhande documenten. Zoals we zagen behoort een vierde deel van de werkzame MMO-ers tot het winkel-, verkoop- en magazijnpersoneel. De helft van hen werkt als vakkenvuller, de andere helft als kassière. Aan de ene kant zien we dus dat de MMO-ers juist de minst gekwalificeerde functies hebben, aan de andere kant oefent $20 \%$ van de MMOers nu reeds een behoorlijk hoog gekwalificeerd beroep uit, zoals bedrijfsleider of handelsvertegenwoordiger. Bij het MMO ligt het functieniveau derhalve verder uiteen, dan bij het MEAO.

Wanneer we het verband bekijken tussen het beroep van de werkende MEAO-ers en MMO-ers en het jaar van afstuderen, blijken er enige verschillen te bestaan. Terwijl van de werkzame groep van de economisch-administratieve opleidingen uit het examenjaar 1988 slechts één op de zeven een functie als assistent-boekhouder of assistent-accountant vervult, blijkt van de corresponderende groep uit 1987 maar liefst ruim één op de drie een dergelijke functie te bekleden. Omgekeerd werkt slechts een kleine $6 \%$ van de werkende schoolverlaters met een economisch-administratieve opleiding uit het examenjaar 1987 als kassière of vakkenvervuller, terwijl van de overeenkomstige groep uit 1988 ruim $22 \%$ deze werkzaamheden verricht.

Ook hier is het niet met zekerheid te zeggen of de constatering dat de schoolverlaters uit 1988 vaker werkzaam zijn in relatief lagere functieniveaus wijst op een verslechtering van de arbeidsmarktsituatie voor wat betreft de aangeboden functies, of een indicatie vormt van arbeidsmarktprocessen, waarbij men eerst een relatief lage functie accepteert om vandaar verder te zoeken naar een baan die beter aansluit op het opleidingsniveau.

86. Dit is enigzins opmerkelijk, aangezien de secretariaatsrichting van het MEAO niet in dit onderzoek heeft geparticipeerd.

87. Zie ook tabellenboek, tabel 27c, 27d, 27g, 27h. 
Met andere woorden: naast het proces van doorstroming naar betere banen kan er ook sprake zijn van verdringing, doordat de arbeidsmarkt verzadigd begint te raken in de beroepssectoren, waarvoor MEAO-ers en MMO-ers zijn opgeleid. Dit betekent dat deze schoolverlaters korte of langere tijd genoegen moeten nemen met functies van een lager niveau, zoals kassière of datatypist. Dit lot lijkt met name MMO-ers te treffen. Op basis van een jaarlijkse herhalingsenquête zou op den duur ook bepaald kunnen worden of de waargenomen ontwikkelingen trendmatig zijn of slechts fluctuaties zijn van jaar op jaar.

\section{MTS en KMBO}

Tabe1 3.10. Beroepen van MTS-ers en KMBO-ers, in procenten

\begin{tabular}{lcc}
\hline BEROEPEN & MTS & KMBO \\
& $\%$ & $\%$ \\
\hline Machinebankwerker, metaalbewerker & 11 & 52 \\
Lasser, constructie-, plaatwerker & 3 & 30 \\
Electromonteur & 13 & -- \\
Loodgieter, verwarmingsmonteur & 2 & 3 \\
Procesarbeider & 9 & 9 \\
Productiemedewerker (lopende band) & 1 & 3 \\
Kwaliteitscontroleur produkten & 4 & -- \\
Technisch tekenaar & 17 & -- \\
Opzichter, landmeter, werkvoorbereider & 8 & -- \\
Electro-, meet- en regel technicus & 5 & -- \\
Natuur-, scheikundig analist, amanuensis & 3 & -- \\
Ander middelbaar technicus & 8 & -- \\
Computer- en automatiseringsdeskundige & 1 & -- \\
Houtbewerker & 1 & -- \\
Bouwvakarbeider, bouwvaktimmerman & 4 & -- \\
Magazijnbediende & 1 & -- \\
(Assistent-)bedrijfsleider & 3 & -- \\
Beroepsmilitair & 3 & -- \\
Andere functie & 2 & 33 \\
\hline Totaal (\%) & & \\
Totaal (abs.) & 100 & \\
\hline & & \\
\hline
\end{tabular}

Bron: ROA (1989) 
Bij een vergelijking van de beroepen van werkende MTS-ers en KMBO-ers blijkt duidelijk dat deze twee groepen schoolverlaters andere functies bekleden (zie tabel 3.10). Daarbij is er ook duidelijk sprake van verschillen in functieniveau. KMBO-ers doen met name uitvoerend productiewerk, MTS-ers werken daarentegen vaker in de productie-voorbereidende sfeer.

Ruim de helft van de werkende KMBO-ers is machinebankwerker of metaalbewerker. Eén op de drie werkzame KMBO-ers heeft een baan als lasser, constructie- of plaatwerker. Een kleine $10 \%$ is als procesarbeider werkzaam. Wat betreft richting zou men kunnen concluderen, dat 20 'n $85 \%$ werk verricht dat aansluit bij de opleiding KMBO-metaaltechnieken.

Bij de MTS-opleiding is de beroepenstructuur diverser. Gezien de verscheidenheid aan participerende opleidingsrichtingen van dit schooltype is dit ook niet verwonderlijk. Van de werkende MTS-ers heeft $17 \%$ een baan als technisch tekenaar. Zo'n $13 \%$ van de MTS-ers is electromonteur. Circa $10 \%$ werkt in beroepen zoals machinebankwerker of metaalbewerker en procesarbeider. Ruim $5 \%$ van de MTS-ers vervult een functie die wat betreft de richting nauwelijks aansluit bij de gevolgde MTS-opleiding. Bovendien kunnen MTS-ers met een bepaalde MTS-opleidingsrichting functies vervullen die meestal ook door MTS-ers met een andere opleidingsrichting worden uitgeoefend. Zo kunnen schoolverlaters met bijvoorbeeld een diploma werktuigbouwkunde als electromonteur werkzaam zijn en omgekeerd. Wat betreft het niveau van de beroepen van de MTS-ers kan worden geconstateerd dat een kwart van de werkende MTSers eenzelfde functie heeft als werkende KMBO-ers in de metaaltechnieken.88

Ook in de beroepenstructuur van de productie-technische opleidingen zit een bepaalde ontwikkeling. Het duidelijkst blijkt dit in de beroepsgroep van machinebankwerkers en metaalbewerkers. Terwijl van de groep met een productie-technische opleiding uit 1988 bijna éénderde in deze beroepsgroep werkzaam is, blijkt van de corresponderende groep uit het examenjaar 1987 slechts $8 \%$ een dergelijke functie te bekleden.

Er kan, net als bij de MEAO-ers en MMO-ers, ook hier naast doorstroming op de arbeidsmarkt naar betere functies, eveneens sprake zijn van een verslechtering van de arbeidsmarktsituatie voor wat betreft het niveau van de aangeboden functies.

88. Zie ook tabellenboek, tabel 27m, 27n, 27q, 27r. 
Een voorbeeld daarvan is, dat MTS-schoolverlaters van 1988, in tegenstelling tot die van 1987, minder goed de technisch productie-voorbereidende functies hebben kunnen bemachtigen waarvoor zij zijn opgeleid en genoegen hebben moeten nemen met functies van een lager niveau, zoals machinebankwerker of metaalbewerker. Ook hier zou op basis van een jaarlijkse herhalingsenquête op den duur bepaald kunnen worden of het gaat om een trendmatige ontwikkeling of slechts jaarlijkse fluctuaties.

\subsubsection{Bedrijjfssectoren}

Bij het bepalen van de bedrijfssector 89 , waarin een schoolverlater werkzaam is, is gebruik gemaakt van de door de Kamers van Koophandel gehanteerde classificatie, de zogenaamde activiteitencode. Deze indeling van (bedrijfs)activiteiten sluit nauw aan bij de Standaard Bedrijfsindeling (SBI) van het CBS. Ook hier wordt bij de bespreking een onderscheid gemaakt tussen de economisch-administratieve en productie-technische opleidingen, zoals ondermeer uit de tabellen 3.11. en 3.12. blijkt.

\section{MEAO en MMO}

Exact $18 \%$ van de werkzame MEAO-ers heeft een baan op een accountants-, administratie- of rechtskantoor en $13 \%$ werkt bij een bank of andere financiële instelling. Bijna een kwart van de MEAO-ers heeft een baan in de industriële sector. De helft van de MMO-ers blijkt in de (detail)handel te werken; $20 \%$ heeft een baan in de industrie en $15 \%$ bij een bank of andere financiële instelling. 90

Wanneer we de verschillen tussen de examenjaren bekijken, zien we een verschuiving optreden die op grond van de resultaten bij de beroepenstructuur te verwachten is. Het aandeel van de handel én van de banken neemt

89. Van alle werkende respondenten is de naam en de plaats van de werkgever bekend. Met behulp van het bedrijvenbestand van de Kamer van Koophandel Midden-Limburg is de code omtrent de bedrijfssectoren (activiteiten) vastgesteld. Eventueel kunnen de antwoorden worden gehercodeerd. Van de activiteitencodes uit de Bedrijfsindeling van de Kamers van Koophandel die niet overeenstemmen met de Standaard Bedrijfsindeling (SBI) van het CBS wordt door de Kamer van Koophandel aangegeven hoe zij zijn gerubriceerd in de Standaard Bedrijfsindeling van het CBS.

90. Zie ook tabellenboek, tabel 27e, $27 i$. 
tussen de examenjaren 1987 en 1988 toe van 11\% naar 36\% (hande1) en van 9\% naar $21 \%$ (banken). Omgekeerd daalt het percentage van de accountants-, rechts- en administratiekantoren tussen 1987 en 1988 van $21 \%$ naar 4\%.91

Tabel 3.11. Bedrijfssectoren, waarin MEAO-ers en MMO-ers werkzaam zijn, in procenten

\begin{tabular}{lcc}
\hline BEDRIJFSSECTOREN & MEAO & MMO \\
\hline Dienstensector & $\%$ & $\%$ \\
Groothandel & 7 & 20 \\
Detailhandel & 2 & 20 \\
Warenhuizen en andere handel sbedrijven & 2 & 10 \\
Transport-, opslag- en communicatiebedrijven & 7 & -- \\
Accountants-, administratie- en rechtskantoren & 18 & 5 \\
Banken en andere financiële instellingen & 13 & 15 \\
Assurantiemaatschappijen en -bemiddeling & 12 & -- \\
Andere zakelijke dienstverlening & 2 & 5 \\
Overheidsbestuur, kadaster & 7 & -- \\
Andere dienstverlenende instelling & 5 & 5 \\
Bouwnijverheid en bouwinstallatiebedrijven & 5 & -- \\
Industrie & 23 & 20 \\
\hline Totaal (\%) & & \\
Totaal (abs.) & 100 & 33 \\
& 147 & \\
\hline
\end{tabular}

Bron: ROA (1989)

MTS en KMBO

Bij het analyseren van tabel 3.12. over de bedrijfssectoren, waarin de schoolverlaters van de productie-technische opleidingen werkzaam zijn, valt direct op, dat de KMBO-ers over minder bedrijfsklassen verspreid zijn. Dit is logisch, aangezien van het KMBO alleen de richting metaaltechnieken in dit onderzoek participeert tegenover zes verschillende opleidingsrichtingen van de MTS. Circa één op drie werkende KMBO-ers heeft een baan in de metaalindustrie. Bijna een even groot deel werkt in de machine- en transportmiddelenindustrie en ongeveer $20 \%$ is te vinden in de chemische-, rubber-

91. Zie ook tabellenboek, tabel $27 f, 27 j$. 
en kunstofverwerkende industrie. In totaal werkt $93 \%$ van de KMBO-ers in de industrie. Daarentegen is slechts de helft van de werkende schoolverlaters met een MTS-opleiding werkzaam in de industriële sector. Nagenoeg $20 \%$ werkt in de machine- en transportmiddelenindustrie en een even grote groep heeft werk in de bouw gevonden. Op een ingenieurs-, architecten- of technisch adviesbureau werkt $10 \%$ van de MTS-ers. 92

Tabel 3.12. Bedrijfssectoren, waarin MTS-ers en KMBO-ers werkzaam zijn, in procenten

\begin{tabular}{|c|c|c|}
\hline BEDRIJFSSECTOREN & $\begin{array}{c}\text { MTS } \\
\% \\
\end{array}$ & $\begin{array}{c}\text { KMBO } \\
\% \\
\end{array}$ \\
\hline \multicolumn{3}{|l|}{ Industrie } \\
\hline Machine- en transportmiddelen & 19 & 31 \\
\hline Metaal industrie & 6 & 35 \\
\hline Chemie, rubber- en kunststof & 6 & 19 \\
\hline Electrotechniek & 7 & -- \\
\hline Papier- en grafische industrie & 3 & 3 \\
\hline Bouwmaterialen, aardewerk, glas & 4 & -- \\
\hline Voedings- en genotmiddelen & 3 & -- \\
\hline Andere bedrijfstak industrie & 2 & 6 \\
\hline \multicolumn{3}{|l|}{ Bouw } \\
\hline Bouwnijverheid & 7 & -- \\
\hline Bouwinstal latiebedrijven & 12 & 3 \\
\hline Openbare nutsbedrijven & 1 & -- \\
\hline \multicolumn{3}{|l|}{ Dienstensector } \\
\hline Handel & 6 & -- \\
\hline Reparatiebedrijven van gebruiksgoederen & 3 & 3 \\
\hline Transport-, opslag- en communicatiebedrijven & 4 & -- \\
\hline Ingenieurs-, architecten, technische adviesburo's & 10 & -- \\
\hline Land-, zee-, luchtmacht & 4 & -- \\
\hline Andere (zakelijke) dienstverlenende instellingen & 3 & -- \\
\hline Landbouw, visserij, delfstoffenwinning & 1 & -- \\
\hline Totaal $(\%)$ & 100 & 100 \\
\hline Totaal (abs.) & 139 & 32 \\
\hline
\end{tabular}

Bron: ROA (1989)

92. Zie ook tabellenboek, tabel $270,27 \mathrm{~s}$. 
Wanneer we kijken naar de verschillen tussen de twee examenjaren, zien we dat de verschillen geringer zijn, dan op basis van de verschuiving in de beroepenstructuur van de MTS-ers en KMBO-ers zou kunnen worden verwacht. Dit duidt erop dat de schoolverlaters van de MTS en het KMBO, meer dan van het MEAO en het MMO, van functie verwisselen zonder te veranderen van branche.93

\section{Bedrijfsomvang}

Van de bedrijven, waarin de schoolverlaters werkzaam zijn, die zijn gevestigd in de regio Midden-Limburg (in casu Roermond-Weert) is de personeelsomvang achterhaald met behulp van het bedrijvenbestand van de Kamer van Koophandel Midden-Limburg. 94

Tabel 3.13. Personeel somvang van de bedrijven, waar de schoolverlaters werkzaam zijn, per schooltype, in procenten

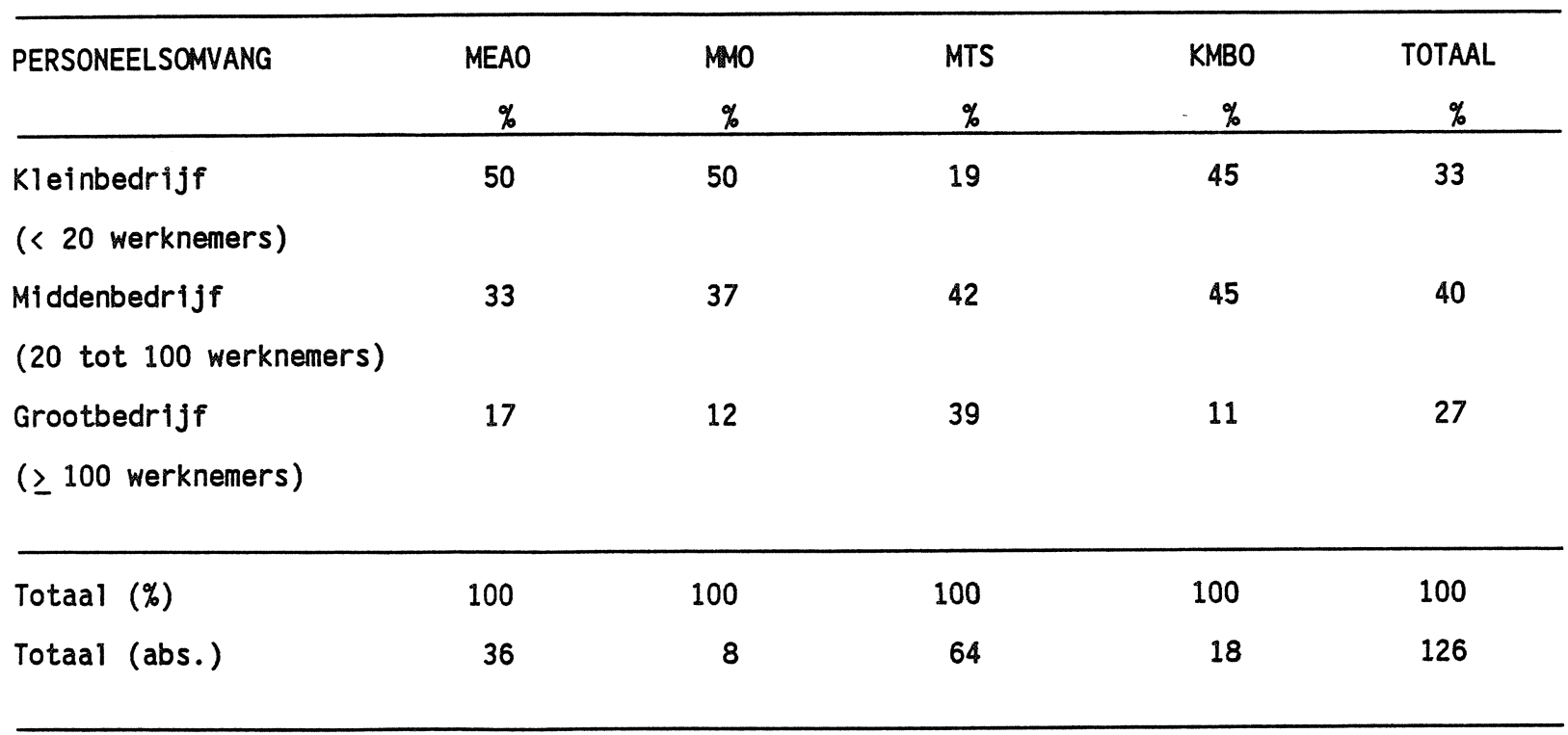

Bron: ROA (1989)

93. Zie ook tabellenboek, tabel 27p, $27 t$.

94. Aangezien niet alle soort bedrijven, die zijn gevestigd, ingeschreven hoeven te staan in het Handelsregister van de Kamer van Koophandel, kon de personeelsomvang niet van alle bedrijfsvestigingen vastgesteld worden. Bovendien zijn holdings ook buiten beschouwing gelaten, daar hiervoor altijd een personeeelsomvang van één persoon wordt opgegeven, terwijl er in werkelijkheid velen bij een dergelijk bedrijf kunnen werken. Bovenstaande heeft als consequentie dat een kwart van de bedrijuen, waar MEAO-ers werken en circa $10 \%$ van de bedrijven waar MMOers en MTS-ers werkzaam zijn, buiten beschouwing blijft. 
Zoals uit tabel 3.13. blijkt, zijn de bedrijven ingedeeld in drie groepen: het kleinbedrijf tot 20 personen, het middenbedrijf van 20 tot 100 personen en het grootbedrijf van 100 personen of meer. Uit deze tabel blijkt, dat de MTS-ers oververtegenwoordigd zijn in het grootbedrijf en ondervertegenwoordigd in het kleinbedrijf. MEAO-ers, MMO-ers en KMBO-ers zijn daarentegen voor een belangrijk deel werkzaam in het kleinbedrijf. 95

\subsubsection{Regionale spreiding}

Tabel 3.14. Regio, waarin schoolverlaters werkzaam zijn, per schooltype, in procenten

\begin{tabular}{lccccc}
\hline REGIO & MEAO & MMO & MTS & KMBO & TOTAAL \\
& $\%$ & $\%$ & $\%$ & $\%$ & $\%$ \\
\hline Noord-oost Nederland & 2 & -- & 2 & 3 & 2 \\
Noord-west Nederland & -- & 6 & 2 & -- & 2 \\
Zuid-west Nederland & -- & -- & 3 & -- & 2 \\
De Peel & -- & 6 & 4 & -- & 4 \\
Eindhoven & -- & -- & 5 & 9 & 16 \\
Weert & 23 & 28 & 13 & -- & 15 \\
Venlo & 13 & 22 & 18 & 42 & 48 \\
Roermond & 60 & 28 & 46 & 27 & 7 \\
Sittard-Geleen & 3 & 6 & 4 & 9 & 3 \\
Heerlen-Maastricht & -- & 6 & 3 & 100 & 100 \\
& & 100 & 100 & 33 & 248 \\
Totaal (\%) & 100 & 18 & 135 & & \\
Totaal (abs.) & 62 & & & & \\
\end{tabular}

Bron: ROA (1989)

Uit tabel 3.14. blijkt, dat $83 \%$ van de MEAO-ers, $56 \%$ van de MMO-ers, $59 \%$ van de MTS-ers en $51 \%$ van de KMBO-ers werkzaam is in de regio Midden-Limburg (de regio's Roermond en Weert samen).96 Van de bedrijven, waar de schoolverlaters werkzaam zijn, is bijna de helft gevestigd in de regio Roermond. Met respectievelijk $16 \%$ en $15 \%$ zijn de regio's Weert en Venlo ook goed vertegenwoordigd. Verder naar het zuiden dalen de percentages echter snel.

95. Zie ook tabellenboek, tabel $6 y$ en $6 z$.

96. Zie ook tabellenboek, tabel $5 \mathrm{~m}, 36 \mathrm{~m}$. 
De overige $12 \%$ van de schoolverlaters werkt in de rest van Nederland 97.

Tussen de schooltypen zijn wel enige verschillen in de locatie van de werkplek. MEAO-ers zijn oververtegenwoordigd in de regio's Roermond en Weert en ondervertegenwoordigd in alle andere gebieden. MEAO-ers werken dus verhoudingsgewijs dichtbij huis. Daarentegen heeft slechts $28 \%$ van de MMOers een baan in de regio Roermond. Een even grote groep werkt in de regio Weert en $22 \%$ in de regio Ven10. De bedrijven, waarin KMBO-ers werken, zijn voor $42 \%$ in de regio Roermond gevestigd. De KMBO-ers zijn ondervertegenwoordigd in de regio Weert, maar oververtegenwoordigd in Zuid-Limburg.98 De MTSers zijn het meeste uitgezwermd over Nederland. Deze groep is echter ondervertegenwoordigd in Weert en Zuid-Limburg.

De reistijd (enkele reis) die de werkende schoolverlaters naar hun werk nodig hebben, is doorgaans zeer kort. Bijna $40 \%$ heeft een reistijd van minder dan een kwartier en ruim $45 \%$ doet over het reizen naar het werk tussen een kwartier tot een half uur. Slechts $15 \%$ van de werkende schoolverlaters heeft hier een langere reistijd voor nodig. De verschillen tussen de schooltypen zijn overeenkomstig de nabijheid van de bedrijven, waar de schoolverlaters van de onderscheiden opleidingen werkzaam zijn. MEAO-ers en KMBO-ers hebben de kortste reistijd en de MTS-ers zijn het langste onderweg. Dit betekent waarschijnlijk ook dat veel schoolverlaters, met name MTS-ers, die buiten Midden-Limburg werk hebben gevonden, (nog) niet naar deze werkregio zijn verhuisd.99

97. Bij de classificatie van de regio's, waar de bedrijven, waarin de respondenten werkzaam zijn, gevestigd zijn, is gebruik gemaakt van de indeling in nodale gebieden. Nederland telt 80 nodale gebieden. Voor een omschrijving van het begrip nodaal gebied wordt $u$ verwezen naar het bijlagenboek. Een aantal nodale gebieden zijn geaggregeerd tot, voor dit onderzoek, relevante regio's.

98. Zoals reeds in hoofdstuk 1 is vermeld, is ook de dependance van de afdeling Metaaltechnieken van het KMBO in het zuidelijker gelegen Heythuysen bij dit onderzoek betrokken. Deze KMBO-ers wonen dus ook in de zuidelijker gelegen regio's en zijn dus bij het zoeken (en vinden) van werk meer op deze zuidelijker gelegen gebieden gericht. Ongeveer een vierde deel van de totale benaderde groep KMBO-ers betreft de dependance in Heythuysen.

99. Zie ook tabellenboek, tabel 50. 
3.3.5. Geografische mobiliteit

Aan degenen, die in Midden-Limburg100 een baan hebben, is gevraagd of $z i j$ bereid zijn een functie buiten deze regio te aanvaarden. Bijna driekwart van deze groep is hiertoe bereid. De verschillen tussen de schooltypen zijn echter aanzienlijk (zie figuur 3.I.).

Figuur 3.I. Percentage in Midden-Limburg werkende schoolverlaters, dat bereid is buiten MiddenLimburg te werken, per schooltype

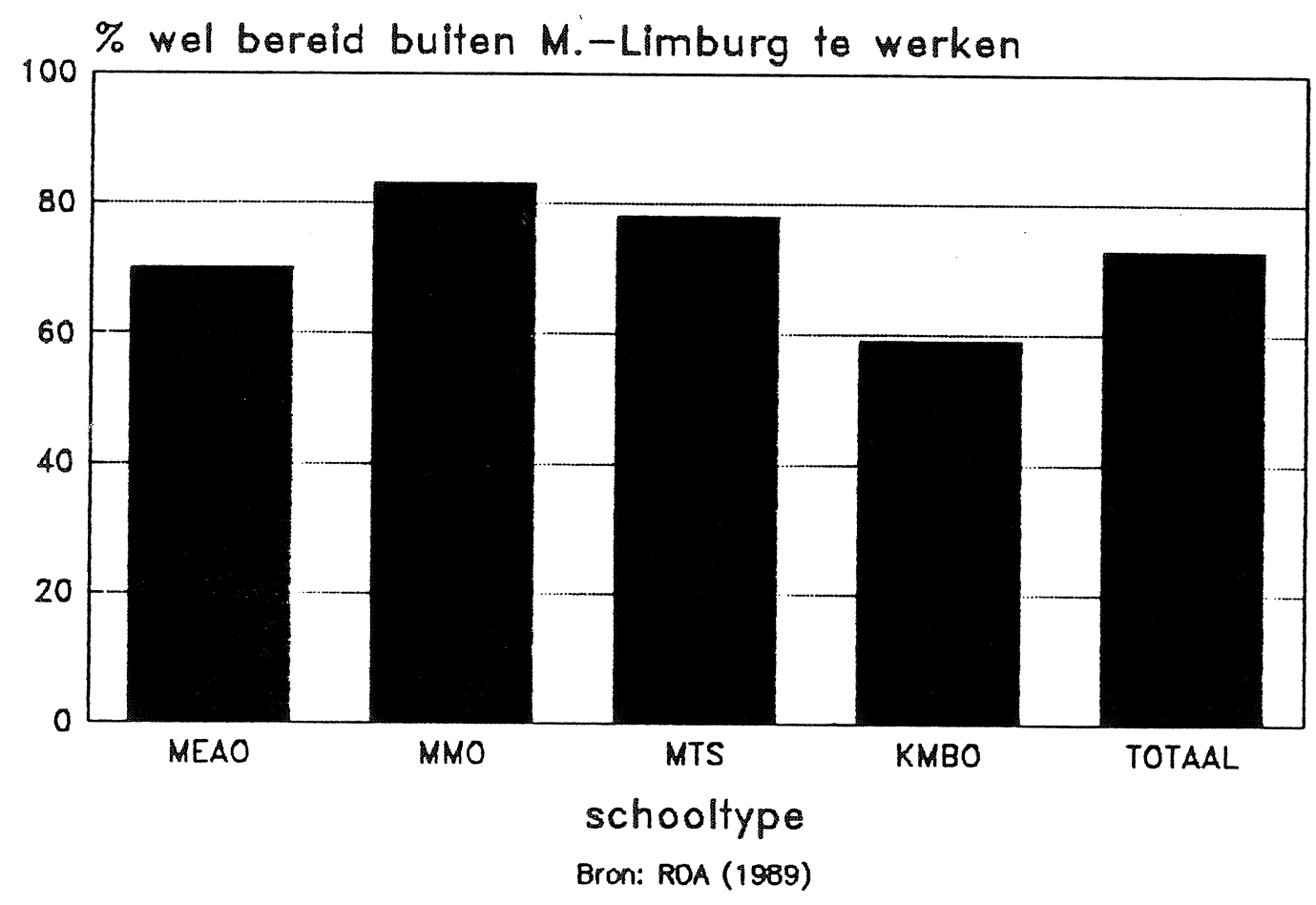

Bij de betreffende groep MMO-ers is de bereidheid met $83 \%$ het grootst, bij de KMBO-ers met $59 \%$ het kleinst. 101 Het is opvallend dat we hier hetzelfde patroon tussen de schooltypen zien als bij de feitelijke spreiding van de werkende schoolverlaters over de regio's. Zoals we zagen in subparagraaf 3.3.4. werken MTS-ers en MMO-ers ook vaker buiten Midden-Limburg dan MEAOers en KMBO-ers.

100. Hoewe $173 \%$ van de werkende schoolverlaters heeft aangegeven dat $z i j$ in Midden-Limburg werkzaam zijn, blijkt uit tabel 3.14. dat in werkelijkheid slechts $63 \%$ in deze regio werkt. De beleving van de grenzen van Midden-Limburg door deze schoolverlaters wijkt dus af van de officiële grenzen.

101. Zie ook tabellenboek, tabel $5 q$. 
Ook is er een kleine verschuiving waar te nemen in de bereidheid tussen de twee examenjaren. Terwijl van de schoolverlaters uit 1987 bijna één op de drie geen functie buiten deze regio zou aanvaarden, zou van de overeenkomstige groep uit 1988 slechts één op de vijf een baan buiten Midden-Limburg weigeren. 102

Tabel 3.15. Regio, tot waar werkende schoolverlater een functie wil aanvaarden, per schooltype, in procenten

\begin{tabular}{lccccc}
\hline REGIO & MEAO & MMO & MTS & KMBO & TOTAAL \\
& $\%$ & $\%$ & $\%$ & $\%$ & $\%$ \\
\hline Overig Limburg & 49 & 50 & 55 & 53 & 53 \\
Gelderland/Noord-Brabant & 14 & 10 & 14 & -- & 12 \\
Overig Nederland & 20 & 30 & 13 & 6 & 15 \\
België/West-Duitsland & 17 & 10 & 18 & 41 & 20 \\
& & & & 100 & 100 \\
Totaal (\%) & 100 & 100 & 100 & 17 & 133 \\
Totaal (abs.) & 35 & 10 & 71 & & \\
\hline
\end{tabular}

Bron: ROA (1989)

Zoals is te zien in tabel 3.15., zou ruim de helft van de werkende schoolverlaters, die bereid zijn een functie buiten Midden-Limburg te aanvaarden, echter alléén een functie in Noord- of Zuid-Limburg accepteren. 103 Opmerkelijk is, dat de KMBO-ers veel vaker geen bezwaar hebben tegen een functie in één van onze buurlanden.

Tenslotte is nagegaan of er een verschil in geografische mobiliteit bestaat tussen de werkende en werkloze schoolverlaters. Gezien het kleine aantal werklozen is het niet zinvol de resultaten daarbij te onderscheiden naar schooltype. Zoals reeds is gezegd, is bijna driekwart van de werkende schoolverlaters, die momenteel een baan heeft in Midden-Limburg, bereid een functie buiten deze regio te aanvaarden. Dit percentage is met $79 \%$ iets hoger bij de werklozen. 104 Van de werklozen, die bereid zijn buiten MiddenLimburg te gaan werken, zou $60 \%$ echter alleen een functie in overig Limburg

102. Zie ook tabellenboek, tabel $5 r$.

103. Zie ook tabellenboek, tabel 5s.

104. Zie ook tabellenboek, tabel $2 \mathrm{~m}$. 
accepteren. 105 0ok dit percentage komt aardig overeen met dit resultaat bij de werkende schoolverlaters. Met andere woorden, er is geen principieel verschil in de bereidheid tot geografische mobiliteit tussen de werkende en werkloze schoolverlaters.

\subsubsection{Inkomen}

In de eerste plaats is gekeken welk inkomen de schoolverlaters uit betaalde arbeid verwerven. Het gaat hier om het netto inkomen per maand in guldens (zie tabel 3.16.).

Het modale inkomen van de werkende schoolverlaters ligt tussen de 1.000 en 1.500 gulden. Een dergelijk salaris verdient $38 \%$ van de werkenden. Een inkomen tussen de 1.500 en 1.750 gulden wordt door circa één van de drie werkenden verdiend. Zo'n 15\% heeft een inkomen tussen de 1.750 en 2.000 gulden. 2.000 gulden of meer ontvangt $7 \%$ van de werkzame schoolverlaters. Daarentegen verdient $10 \%$ nog geen 1.000 gulden netto per maand.

Tabel 3.16. Netto inkomen per maand in guldens, per schooltype, in procenten

\begin{tabular}{|c|c|c|c|c|c|}
\hline INKOMEN & $\begin{array}{c}\text { MEAO } \\
\% \\
\end{array}$ & $\begin{array}{c}\text { MMO } \\
\% \\
\end{array}$ & $\begin{array}{c}\text { MTS } \\
\% \\
\end{array}$ & $\begin{array}{c}\text { KMBO } \\
\% \\
\end{array}$ & $\begin{array}{c}\text { TOTAAL } \\
\% \\
\end{array}$ \\
\hline Minder dan 1.000 & 5 & 28 & 4 & 36 & 10 \\
\hline $1.000-1.500$ & 62 & 33 & 26 & 49 & 38 \\
\hline $1.500-1.750$ & 25 & 28 & 35 & 15 & 30 \\
\hline $1.750-2.000$ & 5 & 11 & 24 & -- & 15 \\
\hline 2.000 of meer & 3 & -- & 11 & -- & 7 \\
\hline Totaal (\%) & 100 & 100 & 100 & 100 & 100 \\
\hline Totaal (abs.) & 61 & 18 & 142 & 33 & 254 \\
\hline Gemiddeld inkomen & 1.390 & 1.355 & 1.625 & 1.215 & 1.500 \\
\hline
\end{tabular}

Bron: ROA (1989)

In het algemeen verdienen KMBO-ers het minste. Ruim één derde deel van hen verdient minder dan 1.000 gulden, bijna de helft tussen de 1.000 en 1.500

105. Zie ook tabellenboek, tabe $12 n$. 
gulden en slechts $15 \%$ werkt voor 1.500 tot 1.750 gulden. Geen enkele KMBO-er heeft een hoger salaris.

Ook de MMO-ers verdienen verhoudingsgewijs weinig. Ruim een kwart van hen verdient nog geen 1.000 gulden. Eén derde deel heeft een salaris van 1.000 tot 1.500 , terwijl ruim een kwart een inkomen van 1.500 tot 1.750 gulden verdient. Ruim $10 \%$ van de MMO-ers neemt daarentegen tussen de 1.750 gulden en 2.000 gulden mee naar huis. Niemand van hen wordt hoger beloond.

De lage inkomens van de MMO-ers en KMBO-ers kunnen voor een deel verklaard worden uit de gemiddeld kortere arbeidsduur per week, die bij de KMBO-ers vooral te maken heeft met hun grote participatie in het leerlingwezen.

Bij MEAO-ers is de inkomensspreiding het geringst. Immers bijna tweederde van hen verdient tussen de 1.000 en 1.500 gulden. Een kwart van de MEAO-ers werkt voor 1.500 tot 1.750 gulden.

De MTS-ers verdienen het meeste. Het modale inkomen ligt tussen de 1.500 en 1.750 gulden per maand. Ruim een derde deel ontvangt een dergelijk bedrag. Slechts enkelen verdienen minder dan 1.000 gulden, een kwart 1.000 tot 1.500 en eveneens een vierde deel heeft een salaris tussen de 1.750 en 2.000 gulden. Ruim $10 \%$ van de MTS-ers verdient 2.000 gulden of meer.

Een mogelijke verklaringsgrond voor de inkomensverschillen tussen de schooltypen is de factor leeftijd. Zowel uiteenlopende minimum jeugdionen voor verschillende leeftijden als leeftijdsafhankelijke salarisschalen in CAO's kunnen hierbij een rol spelen. Zoals reeds is aangegeven in hoofdstuk twee zijn de KMBO-ers het jongste en de MTS-ers het oudste. 106

Bovendien dient men bij een beschouwing van de inkomensverschillen tevens rekening te houden met de (wekelijkse) arbeidsduur107 en onrege lmatige of ploegendiensten 108 .

106. Zie ook tabellenboek, tabel 35u.

107. Zie ook tabellenboek, tabel 35v.

108. Zie ook tabellenboek, tabel $35 z$. 
Ook de aard van de aanstelling heeft invloed op het netto inkomen per maand. Degenen die tijdelijk werk hebben, verdienen beduidend minder dan degenen met een vaste baan. Een inkomen van minder dan 1.000 gulden komt bij hen in een kwart van de gevallen voor, bij de mensen met een vaste aanstelling voor nog geen $6 \%$. Terwijl omgekeerd eveneens een kwart van de werkenden met een vaste aanstelling meer dan zeventienhondervijftig gulden ontvangt. Van de groep met een tijdelijke aanstelling verdient slechts $5 \%$ zoveel. Degenen die een leer-/werkovereenkomst hebben verdienen een salaris tussen de twee andere groepen in.109 Bij deze cijfers moet bedacht worden, dat onder degenen met een tijdelijk arbeidscontract ook meer deeltijdwerkers zitten.

Wanneer de netto inkomens per maand worden afgezet tegen het jaar van afstuderen blijkt er duidelijk enige progressie in de beloning te zitten. Terwijl van de werkenden uit het examenjaar 1988 19\% minder dan 1.000 gulden verdient, verdient nog maar 3\% van de werkende schoolverlaters uit 1987 een dergelijk bedrag. Omgekeerd ontvangt 30\% van het examenjaar 1987 een inkomen van 1.750 gulden of hoger, terwijl slechts $12 \%$ van de werkenden uit 1988 een dergelijk inkomen heeft bereikt. 110

Het inkomen dat de werkenden verdienen kan in principe zó laag zijn, dat dit wordt aangevuld met een uitkering. Slechts enkele werkende schoolverlaters geven aan dat $z i j$, naast een inkomen uit betaalde arbeid, een uitkering ontvangen. Het betreft hier slechts circa $1 \%$ van de groep werkenden. 111

\subsubsection{Functije-aspecten}

De schoolverlaters met werkervaring112 is gevraagd aan te geven welke kenmerken het beste passen bij hun huidige functie én werkgever.113 In tabel 3.17. zijn deze functie-aspecten geordend.

109. Zie ook tabellenboek, tabel 6v.

110. Zie ook tabellenboek, tabel 5v.

111. Zie ook tabellenboek, tabel 5w.

112. Zowel de respondenten die tot de groep betaald werkenden behoren, als diegenen die na het verlaten van het (Kort)MBO langer dan een half jaar bij één werkgever hebben gewerkt, hebben deze vraag beantwoord.

113. Bij deze vraag mochten de respondenten meerdere antwoorden aankruisen. Zodoende is de som van de percentages van de afzonderlijke antwoordmogelijkheden meer dan $100 \%$. 
Tabel 3.17. Functie-aspecten, per schooltype, in procenten

\begin{tabular}{|c|c|c|c|c|c|}
\hline FUNCTIE-ASPECTEN & $\begin{array}{c}\text { MEAO } \\
\% \\
\end{array}$ & $\begin{array}{c}\text { MMO } \\
\% \\
\end{array}$ & $\begin{array}{c}\text { MTS } \\
\% \\
\end{array}$ & $\begin{array}{c}\text { KMBO } \\
\% \\
\end{array}$ & $\begin{array}{c}\text { TOTAAL } \\
\% \\
\end{array}$ \\
\hline Zelfstandig kunnen werken & 76 & 76 & 81 & 90 & 81 \\
\hline Goed met mensen kunnen omgaan & 58 & 64 & 40 & 62 & 49 \\
\hline Technisch inzicht hebben & 6 & 8 & 57 & 62 & 41 \\
\hline Praktisch werken & 32 & 16 & 30 & 28 & 29 \\
\hline Vlug kunnen aanpassen & 32 & 32 & 30 & 18 & 29 \\
\hline Zelf initiatieven ontplooien & 22 & 28 & 32 & 26 & 28 \\
\hline Doorzettingsvermogen & 24 & 28 & 17 & 13 & 19 \\
\hline Jezelf mondeling goed kunnen uiten & 32 & 20 & 12 & 5 & 16 \\
\hline Andermans opdrachten stipt uitvoeren & 18 & 24 & 11 & 5 & 13 \\
\hline Leiding kunnen geven & 3 & 16 & 11 & 3 & 8 \\
\hline Een goede gezondheid hebben & 7 & 20 & 4 & 8 & 7 \\
\hline Risico's durven nemen & 8 & 20 & 6 & 3 & 7 \\
\hline Duidelijk en nauwkeurig kunnen schrijven & 8 & 8 & 6 & 3 & 6 \\
\hline Een ander functie-aspect & 4 & -- & 3 & -- & 2 \\
\hline Totaal (abs.) & 72 & 25 & 162 & 39 & 298 \\
\hline
\end{tabular}

Bron: ROA (1989)

Ruim $80 \%$ van de schoolverlaters met werkervaring noemt "zelfstandig kunnen werken" als een belangrijke vereiste voor het uitoefenen van de huidige functie. Bijna de helft van de werkende schoolverlaters noemt het "goed met mensen kunnen omgaan" als een belangrijk kenmerk, waarbij de MTS met $40 \%$ enigszins is ondervertegenwoordigd. "Technisch inzicht" wordt door circa $60 \%$ van de betreffende MTS-ers en KMBO-ers genoemd. Voor schoolverlaters met werkervaring van de economisch-administratieve opleidingen is dit aspect, zoals verwacht kon worden, veel minder belangrijk. "Praktisch werken" wordt door circa $30 \%$ van de schoolverlaters genoemd. De MMO-ers schijnen dit voor hun functie minder belangrijk te vinden; slechts $16 \%$ van hen merkt dit op. De MMO-ers hechten veel waarde aan het "risico's durven nemen" en een "goede gezondheid". Eén op de vijf onder hen noemt deze kenmerken, terwijl slechts enkele schoolverlaters van de andere schooltypen deze eigenschappen noemen. "Jezelf mondeling goed kunnen uiten" is voor één op de drie MEAO-ers en $20 \%$ van de MMO-ers van belang. Ook "doorzettingsvermogen" is voor de schoolver- 
laters van deze beide opleidingen van betekenis; een kwart van hen noemt deze karakteristiek. "Zelf initiatieven ontplooien" noemt $28 \%$ van de schoolverlaters met werkervaring. Wat dit kenmerk betreft zijn er slechts kleine verschillen tussen de schooltypen. Eveneens een kleine $30 \%$ noemt het "vlug kunnen aanpassen" als een belangrijke eigenschap voor het uitoefenen van de huidige functie. Dit geldt in mindere mate voor het KMBO, waarvan slechts $18 \%$ dit functie-aspect heeft genoemd. Het "stipt uitvoeren van andermans opdrachten" blijkt met name te gelden voor de MMO-ers en MEAO-ers. Respectievelijk bijna $24 \%$ en $18 \%$ van deze schoolverlaters noemt dit kenmerk. "Leiding kunnen geven" blijkt voor $16 \%$ van de MMO-ers en $11 \%$ van de MTSers van belang te zijn. "Jezelf schriftelijk duidelijk en nauwkeurig kunnen uiten" blijkt door slechts $6 \%$ genoemd te worden. In iets hogere mate door MEAO-ers en MMO-ers en nauwelijks door KMBO-ers. 114

Tussen mannen en vrouwen bestaan enkele verschillen in de kenmerken van de huidige functie die worden genoemd. Vrouwen noemen beduidend vaker eigenschappen, zoals "goed met mensen kunnen omgaan", "andermans opdrachten stipt uitvoeren", "mondeling en schriftelijk goed kunnen uiten". Mannen merken de volgende karakteristieken van de huidige functie aanzienlijk vaker op: "praktisch werken", "leiding kunnen geven", "zelf initiatieven ontplooien" en "technisch inzicht".115 Deze discrepantie met betrekking tot het laatste kenmerk hangt natuurlijk direct samen met de overgrote meerderheid van mannen in de technische opleidingen. Uit deze gegevens is echter niet te reduceren of hierbij het schooltype dan wel het geslacht de causale factor is.

114. Zie ook tabellenboek, tabel 18a.

115. Zie ook tabellenboek, tabel $18 \mathrm{~d}$. 



\section{DE KWALITATIEVE AANSLUITING TUSSEN OPLEIDING EN ARBEIDSMARKT}

In dit hoofdstuk wordt ingegaan op wat we in paragraaf 1.1. bestempelde als de verborgen aansluitingsproblemen tussen onderwijs en arbeid, zoals die zich kunnen voordoen in de werksituatie. In de eerste paragraaf wordt het resultaat van een algemeen oordeel over de aansluiting van de gevolgde (Kort) MBO-opleiding op de huidige functie door de werkende schoolverlaters weergegeven. Daarna worden in het licht van deze aansluitingsproblematiek enkele aspecten van de opleiding zelf belicht, zoals de theoretischtechnische kennis, de taal-en praktische vaardigheden, evenals de stage. Tenslotte wordt bekeken of en op welke wijze de schoolverlaters hun kennis en vaardigheden aanvullen met het oog op de huidige en/of toekomstige functies. Daarbij wordt ingegaan op de behoefte aan extra kennis en vaardigheden en de aanvullende cursussen die door de schoolverlaters worden gevolgd. Bovendien wordt aangegeven welke begeleiding de werkende schoolverlaters in hun inwerkperiode hebben gehad.

\subsection{De aansluiting tussen opleiding en functie in het algemeen}

Figuur 4.I. Percentage werkende schoolverlaters dat de huidige functie vindt aansluiten bij hun opleiding, per schooltype, in procenten

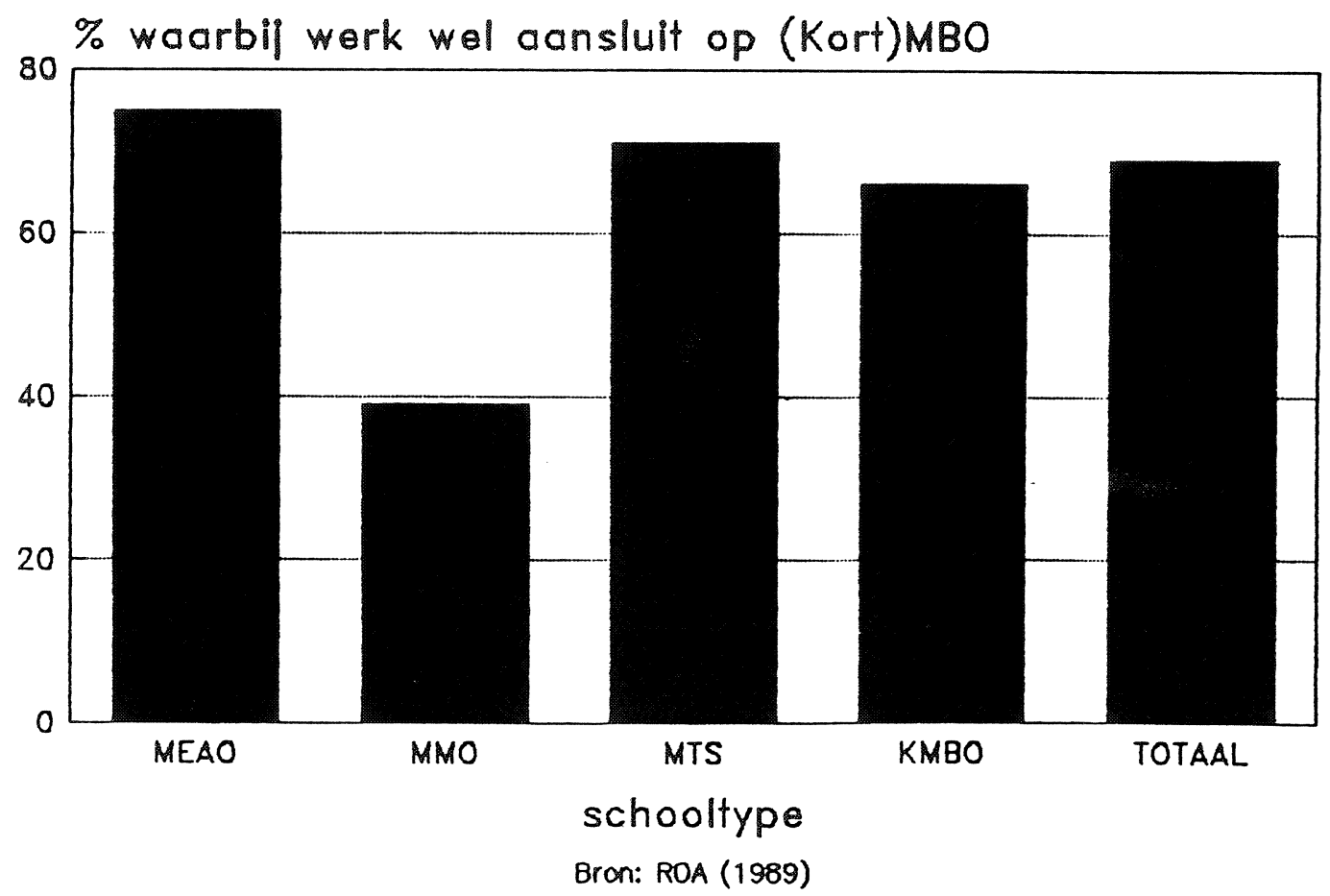


Zoals is af te leiden uit figuur 4.I. is ruim tweederde van de werkende schoolverlaters van mening dat de huidige werkzaamheden aansluiten bij de gevolgde opleiding. Van de werkende MMO-ers deelt echter nog geen $40 \%$ die mening. Bijna tweederde van hen meent dat het werk niet aansluit op de door hen gevolgde MMO-opleiding. 116

Ook tussen de schoolverlaters van de twee examenjaren bestaan verschillen in het oordeel over de aansluiting van het werk op de genoten opleiding. Bijna driekwart van de werkende gediplomeerden uit 1987 vindt dat de huidige functie aansluit bij de door hen gevolgde opleiding. Van de overeenkomstige groep uit 1988 is slechts $62 \%$ deze mening toegedaan.117 Enerzijds wijst dit weer op een mogelijke doorstroming naar beter aansluitende, c.q. hogere functies, anderzijds kan er, zoals gezegd, ook sprake zijn van een verzadiging op de markt als gevolg waarvan schoolverlaters genoegen moeten nemen met functies onder hun niveau. Bovendien kunnen veranderingen in het bedrijfsleven wijzigingen in functie-eisen veroorzaken.

\subsection{Beoordeling van de gevolgde (Kort) MBO-opleiding}

\subsubsection{Theoretisch-technische kennis}

Deze beoordeling vindt voor de vier schooltypen afzonderlijk plaats, daar de geëvalueerde theoretisch-technische kennis voor alle schooltypen verschillend is. Van de door de werkende schoolverlaters gevolgde vakken worden in het kader van de aansluiting op hun huidige functie de volgende aspecten aangegeven:

- het percentage van de werkende schoolverlaters dat vindt dat er voldoende aandacht voor een bepaald (door hen gevolgd) vak is geweest;

- het percentage van de werkende schoolverlaters dat vindt dat de inhoud van een bepaald (door hen gevolgd) vak voldoende actualiteit heeft;

- het percentage van de werkende schoolverlaters dat aangeeft een bepaald (door hen gevolgd) vak bij de huidige functievervulling vaak nodig te hebben.

116. Dit oordeel is gegeven door alle schoolverlaters die betaald werk verrichten. Hierbij is geen onderscheid gemaakt tussen degenen die een beroep hebben dat in principe zou moeten aansluiten op de gevolgde (K)MBO-opleiding en degenen die een andere functie vervullen.

Zie ook tabellenboek, tabel $6 \mathrm{e}$.

117. Zie ook tabellenboek, tabel $6 f$. 
MEAO

Tabel 4.1. Beoordeling theoretisch-technische vakken aan het MEAO, in procenten

\begin{tabular}{|c|c|c|c|}
\hline THEORETISCHE-TECHNISCHE VAKKEN & $\begin{array}{c}\text { VOLDOENDE AANDACHT } \\
\% \\
\end{array}$ & $\begin{array}{c}\text { VOLDOENDE ACTUALITEIT } \\
\% \\
\end{array}$ & $\begin{array}{c}\text { VAAK NODIG } \\
\% \\
\end{array}$ \\
\hline Algemene economie & 73 & 57 & 10 \\
\hline Bedrijfseconomie & 91 & 81 & 41 \\
\hline Commerciële economie & 79 & 73 & 33 \\
\hline Bedrijfsadministratie & 92 & 79 & 62 \\
\hline Computerkunde & 73 & 73 & 58 \\
\hline Informatica & 74 & 52 & 41 \\
\hline Privaatrecht & 84 & 77 & 30 \\
\hline Publ iekrecht & 71 & 86 & 14 \\
\hline Assurantie & 76 & 79 & 35 \\
\hline Distributie & 77 & 85 & 15 \\
\hline Export & 50 & 50 & 50 \\
\hline Wiskunde & 86 & 77 & 9 \\
\hline Statistiek & 83 & 67 & 14 \\
\hline Praktische beroepsvorming & 64 & 57 & 36 \\
\hline Maatschappijleer & 77 & 69 & 12 \\
\hline Gemiddelde beoordeling (\%) & 75 & 66 & 30 \\
\hline
\end{tabular}

+ : een percentage boven het gemiddelde

- : een percentage beneden het gemiddelde

$=:$ een percentage gelijk aan het gemiddelde

Bron: ROA (1989)

Voor de theoretisch-technische MEAO-vakken, vindt gemiddeld driekwart van de MEAO-ers dat voldoende aandacht aan kennisverwerving is besteed (zie ook tabel 4.1.). De percentages voor de verschillende vakken lopen hierbij uiteen van $50 \%$ tot $92 \%$. De actualiteit van de gevolgde vakken wordt iets minder positief beoordeeld. Tweederde van de werkende MEAO-ers, die deze vakken gevolgd hebben, vindt dat deze vakken gemiddeld voldoende actueel waren. De score voor het aspect actualiteit van de theoretisch-technische 
kennis varieert tussen de $50 \%$ en $86 \%$. Bijna één op de drie werkende MEAO-ers blijkt gemiddeld van de gevolgde vakken aan te geven, dat zij deze vakken frequent gebruiken in de dagelijkse beroepspraktijk. Op dit punt lopen de scores van de verschillende vakken ver uiteen, namelijk van $9 \%$ tot $62 \% .118$

Algemene economie wordt, in tegenstelling tot commerciële en bedrijfseconomie, niet alleen door minder MEAO-ers goed beoordeeld, maar ook door minder MEAO-ers vaak gebruikt in de beroepspraktijk. Bedrijfsadministratie, dat bijna tweederde en assurantie dat ruim éénderde van de MEAO-ers vaak bij de uitoefening van de functie nodig heeft, komen goed uit de bus. Aan computerkunde en informatica, wat ongeveer de helft van de MEAO-ers in de huidige functie regelmatig gebruikt, kan niet alleen meer aandacht besteed worden, maar dient, met name bij informatica, meer rekening gehouden te worden met de actuele ontwikkelingen in het bedrijfsleven. Juist omdat één op de drie MEAO-ers aangeeft dat zij geregeld gebruik maken van het vak praktische beroepsvorming, is het van belang dat aan dit vak zowel in kwantitatieve, als kwalitatieve zin meer aandacht besteed gaat worden.

MMO

Van de werkende MMO-ers vindt gemiddeld ruim driekwart dat voldoende aandacht is besteed aan de gevolgde vakken, zoals men kan concluderen uit tabe 1 4.2. De percentages lopen op dit punt uiteen van $50 \%$ tot en met $96 \%$ (een score van $0 \%$ voor het vak assurantie, dat slechts door enkelen is gevolgd, daargelaten). De actualiteit van de gevolgde vakken wordt gemiddeld door $70 \%$ van de werkende MMO-ers als voldoende beschouwd. Op het punt van de actualiteit van de vakken aan het MMO variëren de percentages tussen de $40 \%$ en $88 \%$. Door gemiddeld bijna de helft van de MMO-ers wordt van de gevolgde vakken aangegeven, dat $z i j$ deze vakken frequent bij de huidige functievervulling benutten. De scores lopen hierbij uiteen van $17 \%$ tot en met $100 \% .119$

De in de beroepsprakijk veel benutte vakken algemene en bedrijfseconomie, warenkennis, commerciële vorming en marketing worden door velen goed beoordeeld. Jammer is het derhalve dat de veel gebruikte vakken bedrijfsadministratie en reclame onvoldoende scoren. Aan management, welk vak veel MMO-ers positief beoordelen, komt men in de huidige functie verhoudingsgewijs minder toe.

118. Zie ook tabellenboek, tabellen $19 \mathrm{a} \mathrm{t} / \mathrm{m} 19 \mathrm{~d}$.

119. Zie ook tabellenboek, tabellen $20 \mathrm{a} \mathrm{t} / \mathrm{m} 20 \mathrm{~d}$. 
Tabel 4.2. Beoordeling theoretisch-technische vakken aan het MMO, in procenten

\begin{tabular}{|c|c|c|c|c|}
\hline \multirow{2}{*}{$\begin{array}{l}\text { THEORETISCHE-TECHNISCHE VAKKEN } \\
\text { Algemene economie }\end{array}$} & \multicolumn{2}{|c|}{$\begin{array}{c}\text { VOLDOENDE AANDACHT } \\
\% \\
\end{array}$} & $\begin{array}{c}\text { VOLDOENDE ACTUALITEIT } \\
\% \\
\end{array}$ & $\begin{array}{l}\text { VAAK NODIG } \\
\% \\
\end{array}$ \\
\hline & + & 96 & 83 & 50 \\
\hline Bedrijfseconomie & + & 88 & 76 & 48 \\
\hline Bedrijfsadministratie & - & 70 & 61 & 52 \\
\hline Warenkennis & + & 84 & 72 & 60 \\
\hline Reclame & - & 60 & 40 & 80 \\
\hline Assurantie & - & -- & 50 & 100 \\
\hline Marketing & $=$ & 77 & 77 & 69 \\
\hline Management & + & 83 & 78 & 43 \\
\hline Recht & + & 78 & 74 & 26 \\
\hline Wiskunde & - & 50 & 50 & 17 \\
\hline Statistiek & - & 61 & 67 & 28 \\
\hline Commerciële vorming & + & 84 & 88 & 68 \\
\hline Esthetische vorming & - & 67 & 50 & 33 \\
\hline Maatschappijleer & - & 74 & 48 & 30 \\
\hline Gemiddelde beoordeling (\%) & & 77 & 70 & 47 \\
\hline $\begin{array}{l}+: \text { een percentage boven het gen } \\
- \text { : een percentage beneden het } \\
=: \text { een percentage gelijk aan h}\end{array}$ & $\begin{array}{l}\text { ddel de } \\
\text { middel de } \\
\text { gemiddeld }\end{array}$ & & & \\
\hline
\end{tabular}

Bron: ROA (1989)

Tussen het MMO en het MEAO zijn enkele opmerkelijke verschillen te constateren. Hoewel zowel MEAO-ers als MMO-ers vaak bedrijfsadministratie toepassen in hun huidige functie, beoordelen MEAO-ers het vak veel vaker positief dan MMO-ers. Omgekeerd wordt het vak beroepsvorming, dat vaak bij de functievervulling wordt benut, vaker door de MMO-ers als voldoende beoordeeld. Algemene economie wordt zowel veelvuldiger door MMO-ers gebruikt als positief beoordeeld. Verder is het opvallend dat ondersteunende vakken zoals, wiskunde, statistiek en maatschappijleer, die men niet vaak bij de functievervulling gebruikt, bij het MMO door aanzienlijk minder en bij het MEAO door beduidend meer schoolverlaters dan gemiddeld als voldoende worden beoordeeld. 
MTS

Tabel 4.3. Beoordeling theoretisch-technische vakken aan het MTS, in procenten

\begin{tabular}{|c|c|c|c|c|c|c|}
\hline \multirow{3}{*}{$\begin{array}{l}\text { THEORETISCHE-TECHNISCHE VAKKEN } \\
\text { wiskunde, natuurkunde, scheikunde } \\
\text { computerkunde }\end{array}$} & \multicolumn{2}{|c|}{$\begin{array}{c}\text { VOLDOENDE AANDACHT } \\
\% \\
\end{array}$} & \multicolumn{2}{|c|}{$\begin{array}{c}\text { VOLDOENDE ACTUALITEIT } \\
\% \\
\end{array}$} & \multicolumn{2}{|c|}{$\begin{array}{c}\text { VAAK NODIG } \\
\% \\
\end{array}$} \\
\hline & + & 91 & + & 84 & - & 43 \\
\hline & - & 35 & - & 26 & - & 39 \\
\hline technologie & + & 92 & $=$ & 71 & + & 51 \\
\hline bedrijfskunde & + & 86 & + & 77 & - & 32 \\
\hline bouwkundige constructies & - & 79 & - & 67 & + & 51 \\
\hline sterkteleer & + & 91 & + & 80 & - & 32 \\
\hline bouw- en landmeten & - & 73 & - & 67 & + & 58 \\
\hline weg- en waterbouwkunde & + & 83 & - & 67 & + & 78 \\
\hline electriciteitsleer & $=$ & 81 & + & 72 & + & 58 \\
\hline schakel- en regeltechniek & - & 60 & - & 58 & + & 56 \\
\hline energietechniek & + & 90 & $=$ & 71 & + & 60 \\
\hline electronica & + & 82 & - & 66 & + & 68 \\
\hline procestechniek & + & 93 & + & 87 & + & 53 \\
\hline meet- en regeltechniek & - & 64 & - & 52 & + & 55 \\
\hline milieutechniek & - & 73 & + & 91 & + & 82 \\
\hline werktuigbouwkunde & + & 95 & + & 79 & + & 52 \\
\hline staal constructies & + & 94 & + & 81 & - & 38 \\
\hline transport- en warmtewerktuigen & + & 82 & - & 68 & + & 53 \\
\hline pneumatiek, hydrauliek & + & 94 & + & 81 & + & 50 \\
\hline Gemiddel de beoordeling (\%) & & 81 & & 71 & & 48 \\
\hline
\end{tabular}

+ : een percentage boven het gemiddelde

- : een percentage beneden het gemiddelde

$=$ : een percentage gelijk aan het gemiddelde

Bron: ROA (1989) 
Van de werkende MTS-ers is $81 \%$ van mening dat er gemiddeld aan de gevolgde vakken voldoende aandacht is besteed. De percentages lopen hierbij uiteen van $60 \%$ tot $95 \%$, met uitzondering van een zeer lage score van $35 \%$ voor computerkunde. Op het punt van de actualiteit van de gevolgde vakken is gemiddeld $71 \%$ van de werkende MTS-ers van mening dat dit voldoende is. De resultaten variëren hier tussen de $26 \%$ en $91 \%$. Opnieuw wordt computerkunde door weinig MTS-ers positief beoordeeld. Gemiddeld wordt door $48 \%$ van de werkende MTS-ers aangegeven, dat zij een bepaald vak in de huidige functie vaak gebruiken. De resultaten lopen hierbij uiteen van $32 \%$ tot $82 \% .120$

Juist omdat ruim de helft van de MTS-ers aangeeft dat zij de vakken bouwkundige constructies, schakel- en regeltechnieken, alsmede meet- en regeltechnieken regelmatig bij de functie-uitoefening nodig heeft, is het van belang dat zowel in kwantitatieve als kwalitatieve zin meer aandacht aan deze vakken besteed gaat worden.

\section{KMBO}

Gemiddeld vindt $78 \%$ van de werkende KMBO-ers dat er in hun opleiding voldoende aandacht is besteed aan de door hen gevolgde vakken. De scores variëren hierbij tussen de $38 \%$ en $92 \%$. Van de gevolde vakken vindt gemiddeld tweederde van de KMBO-ers dat deze vakken voldoende actueel zijn. De resultaten, wat betreft de actualiteit van de vakken, lopen uiteen van $40 \%$ tot $86 \%$. Tenslotte heeft gemiddeld $53 \%$ van de KMBO-ers aangegeven, dat zij de gevolgde vakken frequent nodig hebben bij het uitoefenen van de huidige werkzaamheden. De uitkomsten lopen hierbij uiteen van $10 \%$ tot $82 \%$.

Net als bij de MTS scoort het vak computerkunde bij het KMBO zeer laag. Aan zowel dit vak als de vakken materialenleer en pneumatiek / hydrauliek kan meer aandacht in kwantitatieve en kwalitatieve zin worden geschonken, waarbij bedacht kan worden, dat het vak materialenleer overigens wel door meer KMBO-ers wordt benut. De vakken die het nauwst verbonden zijn aan de opleiding metaaltechnieken, zoals constructieleer, metaalbewerking en machinebankwerken worden niet alleen door veel KMBO-ers positief beoordeeld, maar ook het veelvuldigst in de beroepspraktijk gebruikt.121

120. Zie ook tabellenboek, tabellen $21 \mathrm{a} \mathrm{t} / \mathrm{m} 21 \mathrm{~d}$.

121. Zie ook tabellenboek, tabel $22 \mathrm{a} t / \mathrm{m} 22 \mathrm{~d}$. 
Tabe1 4.4. Beoordeling theoretisch-technische vakken aan het KMBO, in procenten

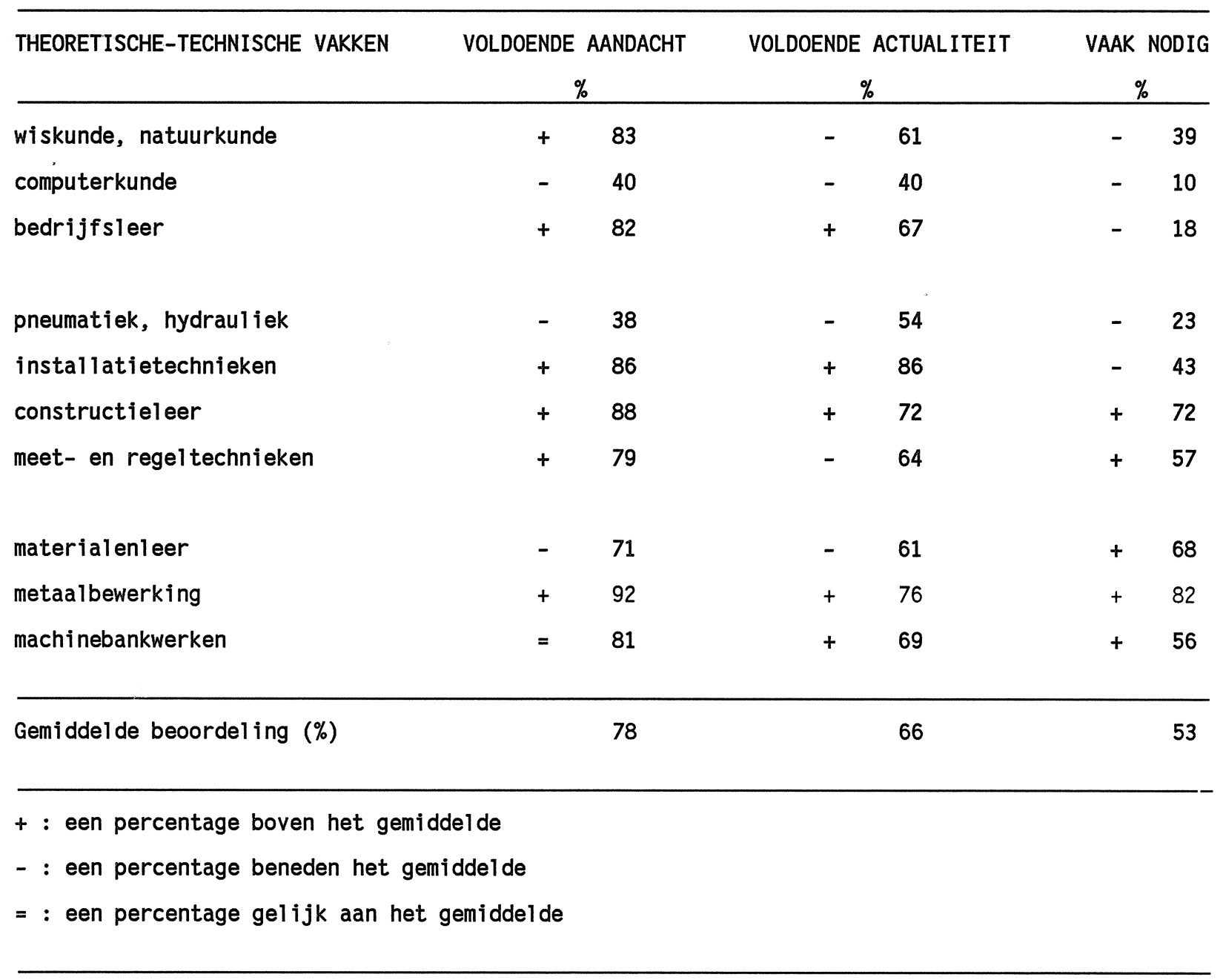

Bron: ROA (1989)

Wat betreft de verschillen tussen de schooltypen kan het volgende worden opgemerkt (zie figuur 4.II.). De aandacht die aan het (Kort) MBO aan de technisch-theoretische kennis is besteed wordt door ruim driekwart van de schoolverlaters als voldoende beschouwd. Voor de MTS geldt zelfs een groter deel, namelijk royaal viervijfde.

Ook op het punt van de beoordeling van de actualiteit van de gevolgde vakken blijkt een duidelijke overeenkomst te zijn tussen de schooltypen. Ruim tweederde van de werkende schoolverlaters is van mening dat de kennis die is opgedaan aan het (Kort) MBO voldoende actueel is. Het MMO en de MTS scoren wat dit betreft met circa $70 \%$ nog iets hoger.

De MEAO-ers maken gemiddeld minder gebruik van de in hun opleiding gevolgde vakken, dan de werkenden van de drie andere schooltypen. Van de werkende 
MEAO-ers geeft slechts een derde aan, dat zij de gevolgde vakken in de dagelijkse beroepspraktijk frequent nodig hebben. Voor de overige schooltypen geldt dit voor circa de helft van de werkenden. Kennelijk geldt voor de MEAO dat de relatie van een groot aantal vakken uit de opleiding met het beroepenveld wat minder direct is dan voor de andere opleidingen. Zo wie zo worden de ondersteunende vakken, zoals wiskunde, natuurkunde, statistiek en maatschappijleer minder vaak (direct) in de beroepsprakijk gebruikt.

Tenslotte nog een opmerking over het vak computerkunde. Ofschoon met name de technisch geschoolden dit vak vaak negatief beoordelen, gebruiken slechts weinigen onder hen dit vak regelmatig bij de uitoefening van hun functie. Veel MEAO-ers daarentegen beoordelen dit vak positief en maken er in hun beroepspraktijk dikwijls gebruik van.

Figuur 4.II. Percentage werkende schoolverlaters dat gemiddeld de aandacht en de actualiteit als voldoende beoordeelt en de vakken regelmatig in de huidige functie gebruikt, per schooltype

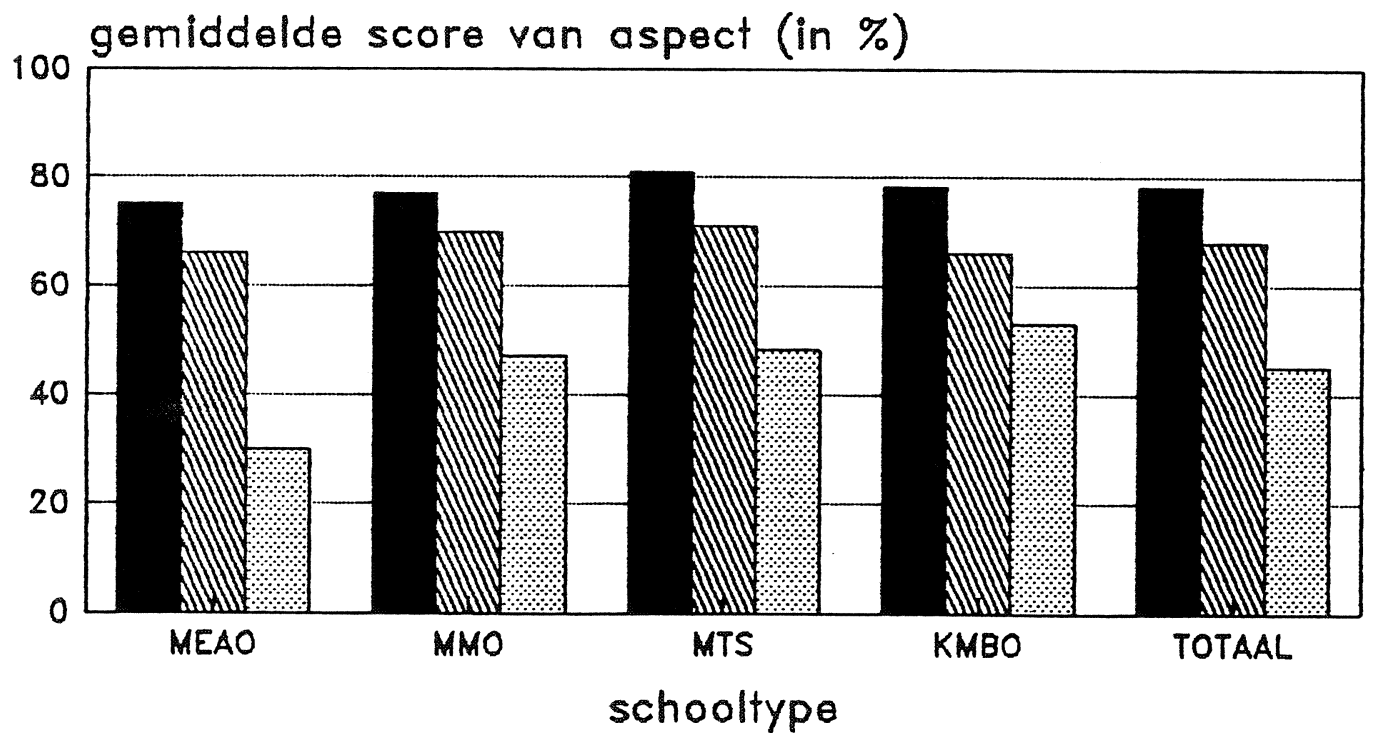

voldoende candacht

Bron: ROA (1989)

\subsubsection{Taalvaardigheden}

De taalvaardigheden zijn voor iedere taal, die de schoolverlaters hebben gevolgd, afzonderlijk aan de hand van de volgende vragen beoordeeld: 
- is er voldoende aandacht besteed aan de mondelinge taalvaardigheid?;

- is er voldoende aandacht besteed aan de schriftelijke taalvaardigheid?;

- wordt de taal in de huidige functie vaak gebruikt?

De resultaten staan in de figuren 4. III.a.t/m c. afgebeeld. 122

Figuur 4.III.a. Percentage werkende schoolverlaters dat gemiddeld de aandacht voor mondelinge taalvaardigheid als voldoende beoordeelt, per schooltype

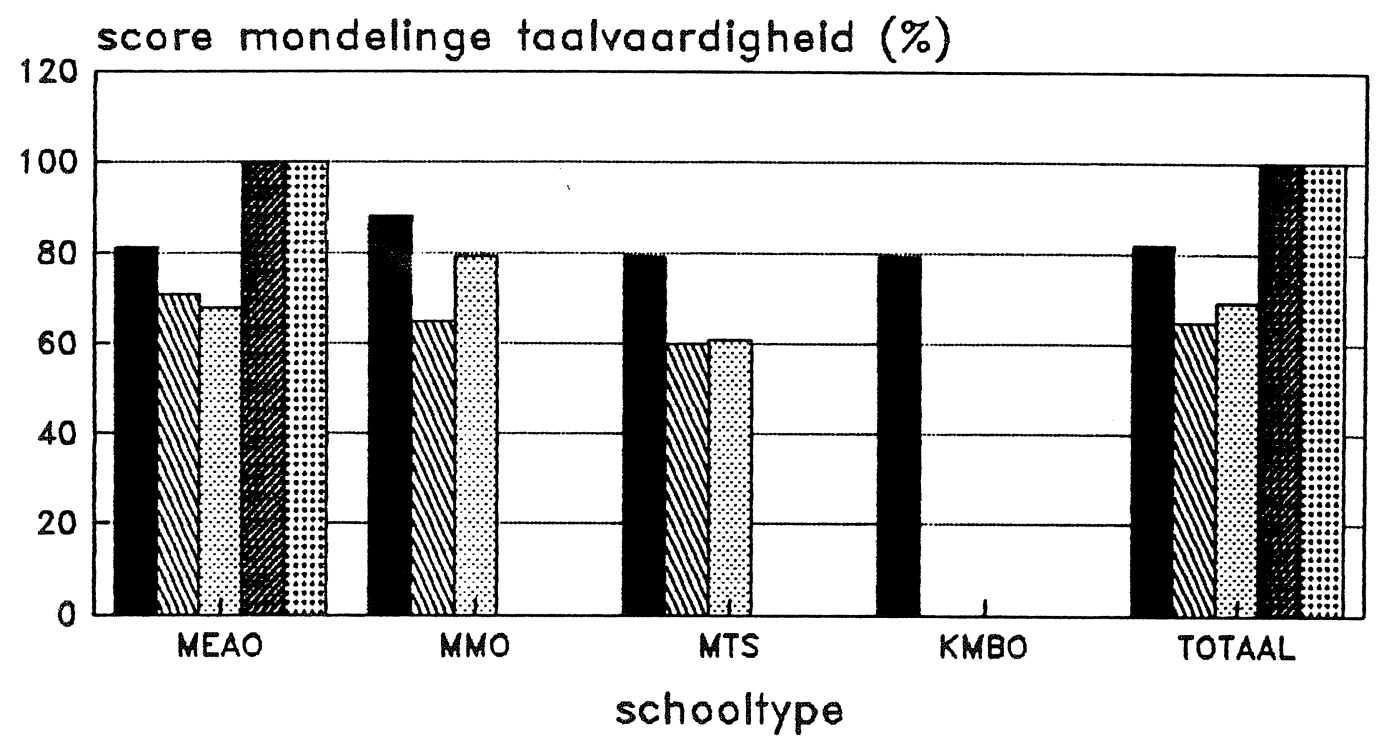

Noderlands Mllll Engols Dults Frans

Bron: ROA (1989)

Over het algemeen wordt de aandacht die er in de opleiding is geweest voor de schriftelijke taalvaardigheid beter beoordeeld dan de aandacht voor de mondelinge taalvaardigheid. Dit geldt met name voor de vreemde talen. De KMBO-ers vormen hierop een uitzondering. Bij zowel het MEAO, het MMO, als het KMBO vindt ruim driekwart van de werkenden dat er aan mondelinge vaardigheden voldoende aandacht is besteed. Van de MTS deelt slechts tweederde deze mening. De MMO-ers blijken de gevolgde talen in de beroepspraktijk het veelvuldigste nodig te hebben, gevolgd door de MEAO-ers, de MTS-ers en tenslotte de KMBO-ers. De MEAO-ers en de MMO-ers beoordelen de onderwezen taalvaardigheden over het algemeen positiever dan de technisch geschoolden.

122. Op deze vraag konden de respondenten meer dan één antwoord (taal) aankruisen, zodat de som van de percentages van de afzonderlijke antwoorden (talen) meer dan $100 \%$ bedraagt. De KMBO-ers konden echter alleen de taalvaardigheden van het vak Nederlands beoordelen, aangezien hen geen andere talen tijdens de KMBO-opleiding zijn onderwezen. Zie ook tabellenboek, tabel 23a t/m 23d. 
Figuur 4.III.b. Percentage werkende schoolverlaters dat gemiddeld de aandacht voor schriftelijke taalvaardigheld als voldoende beoordeelt, per schooltype

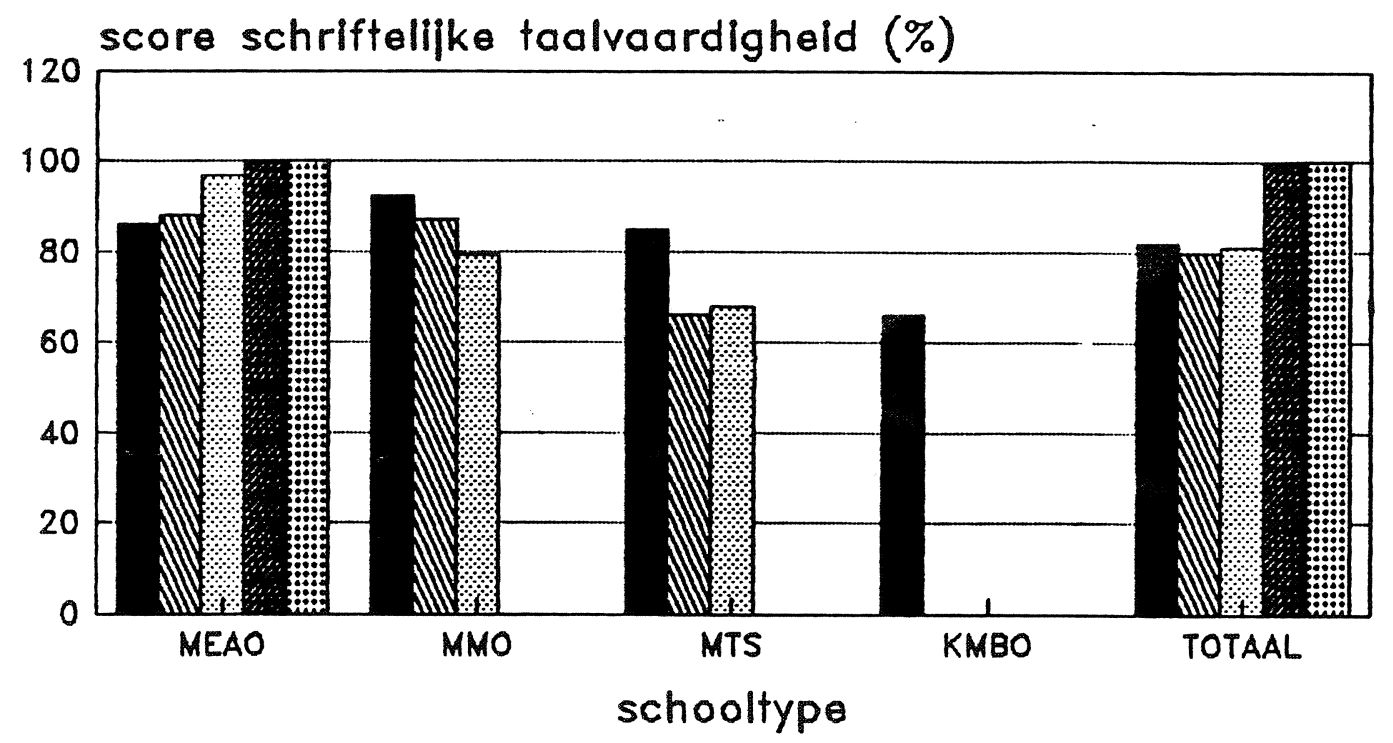

Nederlands $\quad$ Mllll Engels Dults Frans

Bron: ROA (1989)

Figuur 4.III.C. Percentage werkende schoolverlaters dat gemiddeld een bepaalde taal nodig heeft in huidige functie, per schooltype

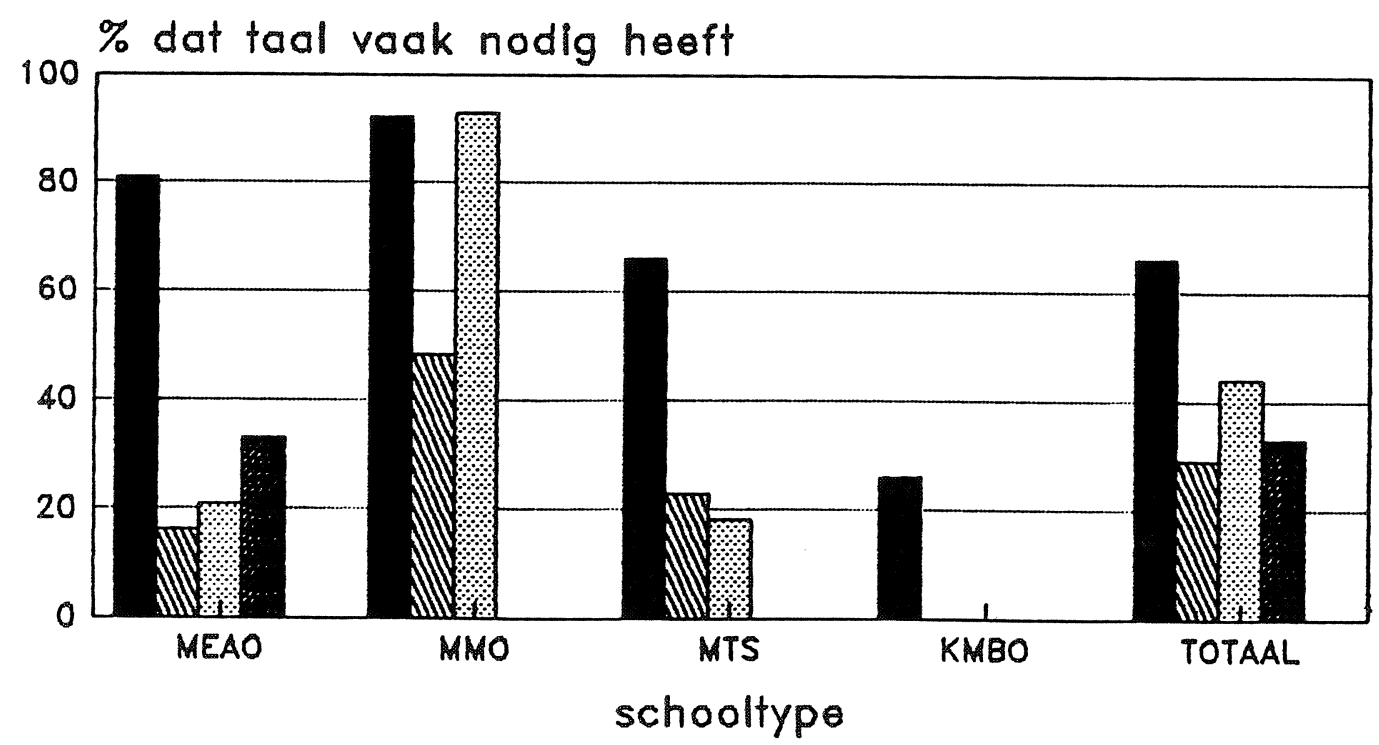

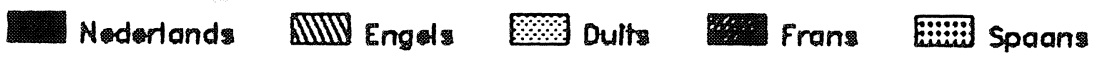

Bron: ROA (1989)

\subsubsection{Praktische vaardigheden}

De praktische vaardigheden zijn onderscheiden naar de volgende onderdelen: 
- apparatuur en machines;

- materiaal en gereedschap;

- software.

Met betrekking tot deze drie onderdelen hebben de werkende schoolverlaters de volgende vragen beantwoord:

- is er voldoende geoefend met de praktijkonderdelen?;

- waren de praktijkonderdelen verouderd?;

- waren de praktijkonderdelen te modern?;

- worden de praktijkonderdelen vaak gebruikt in de huidige functie?

De resultaten van de beoordeling van de verschillende aspecten en onderdelen van de praktijkoefeningen worden weergegeven in de tabellen $4.5 . \mathrm{t} / \mathrm{m} \mathrm{4.7.123}$

Tabel 4.5. Percentage schoolverlaters dat vindt dat de genoemde praktijkonderdelen voldoende geoefend zijn, per schooltype

\begin{tabular}{lccccc}
\hline ONDERDELEN & MEAO & MMO & MTS & KMBO & \multicolumn{2}{c}{ TOTAAL } \\
& $\%$ & $\%$ & $\%$ & $\%$ & 48 \\
\hline Apparatuur, machines & 35 & 28 & 51 & 71 & 51 \\
Materiaal, gereedschap & 33 & 32 & 57 & 71 & 25 \\
Software & 54 & 12 & 17 & 17 & 292 \\
\hline Totaal (abs.) & 70 & 21 & 162 & 39 & \\
\hline
\end{tabular}

Bron: ROA (1989)

Uit tabel 4.5. blijkt, dat de technisch geschoolden vaker vinden dat er voldoende met apparatuur en machines is geoefend, dan de MMO-ers en MEAOers. Hetzelfde beeld geldt voor materiaal en gereedschap. Wat betreft software zijn de resultaten geheel anders. Ruim de helft van de werkende MEAO-ers meent dat hiervoor voldoende praktijkoefening is geweest. Daarentegen meent het overgrote deel van de schoolverlaters van de drie overige schooltypen dat te weinig met software is geoefend.124 Over het algemeen vinden de KMBO-ers het veelvuldigst dat de praktijkonderdelen voldoende geoefend zijn, gevolgd door de MTS-ers en de MEAO-ers. MMO-ers daarentegen menen het minst frequent dat er voldoende praktijkoefening is geweest.

123. Ook op deze vragen konden de respondenten meer dan één antwoord aankruisen, zodat de som van de percentages van de afzonderlijke antwoorden meer dan $100 \%$ bedraagt.

124. Zie ook tabellenboek, tabel $24 a$. 
Tabel 4.6. Percentage schoolverlaters dat vindt dat de genoemde praktijkonderdelen verouderd zijn, per schooltype

\begin{tabular}{lccccc}
\hline ONDERDELEN & MEAO & MMO & MTS & KMBO & TOTAAL \\
& $\%$ & $\%$ & $\%$ & $\%$ & $\%$ \\
\hline Apparatuur, machines & 24 & 28 & 47 & 26 & 37 \\
Materiaal, gereedschap & 22 & 28 & 30 & 24 & 27 \\
Software & 24 & 28 & 47 & 12 & 35 \\
\hline Totaal (abs.) & 68 & 19 & 159 & 38 & 284 \\
\hline
\end{tabular}

Bron: ROA (1989)

Circa een kwart van de werkende schoolverlaters van het MEAO, het MMO en het KMBO vindt dat de apparatuur en machines, waarmee men praktijkoefeningen moest doen, verouderd zijn (zie tabel 4.6.). Van de werkende MTS-ers vindt dit zelfs $47 \%$. Het gebruikte materiaal en gereedschap wordt eveneens door ongeveer een vierde deel van de werkenden als verouderd bestempeld. Met name de MTS-ers vinden de aan de opleiding gebruikte software verouderd. MTS-ers vinden beduidend vaker dan de schoolverlaters van de andere drie schooltypen, dat de praktijkonderdelen verouderd zijn.125 In principe kunnen de praktische vaardigheden ook te ver vooruitiopen op datgene wat in de beroepspraktijk wordt gebruikt. Bijvoorbeeld omdat de schoolverlaters bij bedrijven terecht komen, waar met minder geavanceerde apparatuur wordt gewerkt. Dit blijkt echter nauwelijks voor te komen.126

Zoals blijkt uit tabel 4.7., hebben MEAO-ers vaker software, evenals apparatuur en machines geregeld in hun functie nodig. Voor de MTS-ers en KMBO-ers spelen naast apparatuur en machines vooral materiaal en gereedschap in de dagelijkse beroepspraktijk een belangrijke rol. KMBO-ers komen het minst met software in aanraking. Bovendien valt op dat over het algemeen aanmerkelijk minder MMO-ers praktijkonderdelen noemen die zij in de huidige functie vaak nodig hebben. Dit vormt wederom een indicatie dat MMO-ers vaker werk hebben, dat minder goed aansluit op hun opleiding.127 Er is daarbij duidelijk sprake van onderbenutting (zie paragraaf 1.1.).

125. Zie ook tabellenboek, tabel $24 \mathrm{~b}$.

126. Zie ook tabellenboek, tabel 24c.

127. Zie ook tabellenboek, tabel $24 d$. 
Tabel 4.7. Percentage schoolverlaters dat genoemde praktijkonderdelen vaak nodig heeft in de beroepspraktijk, per schooltype

\begin{tabular}{lccccc}
\hline ONDERDELEN & MEAO & MMO & MTS & KMBO & \multicolumn{2}{c}{ TOTAAL } \\
& $\%$ & $\%$ & $\%$ & $\%$ & 52 \\
\hline Apparatuur, machines & 61 & 28 & 50 & 61 & 53 \\
Materiaal, gereedschap & 32 & 24 & 30 & 12 & 37 \\
Software & 68 & 36 & & 38 & 279 \\
\hline Totaal (abs.) & 68 & 19 & & \\
\end{tabular}

Bron: ROA (1989)

Tot slot kan worden gesteld dat de praktijkvaardigheden over het algemeen minder goed worden beoordeeld dan de theoretisch-technische kennis en de taalvaardigheden.

\subsubsection{De stage}

Figuur 4.IV. Mening van werkende schoolverlaters over stageduur, per schooltype, in procenten

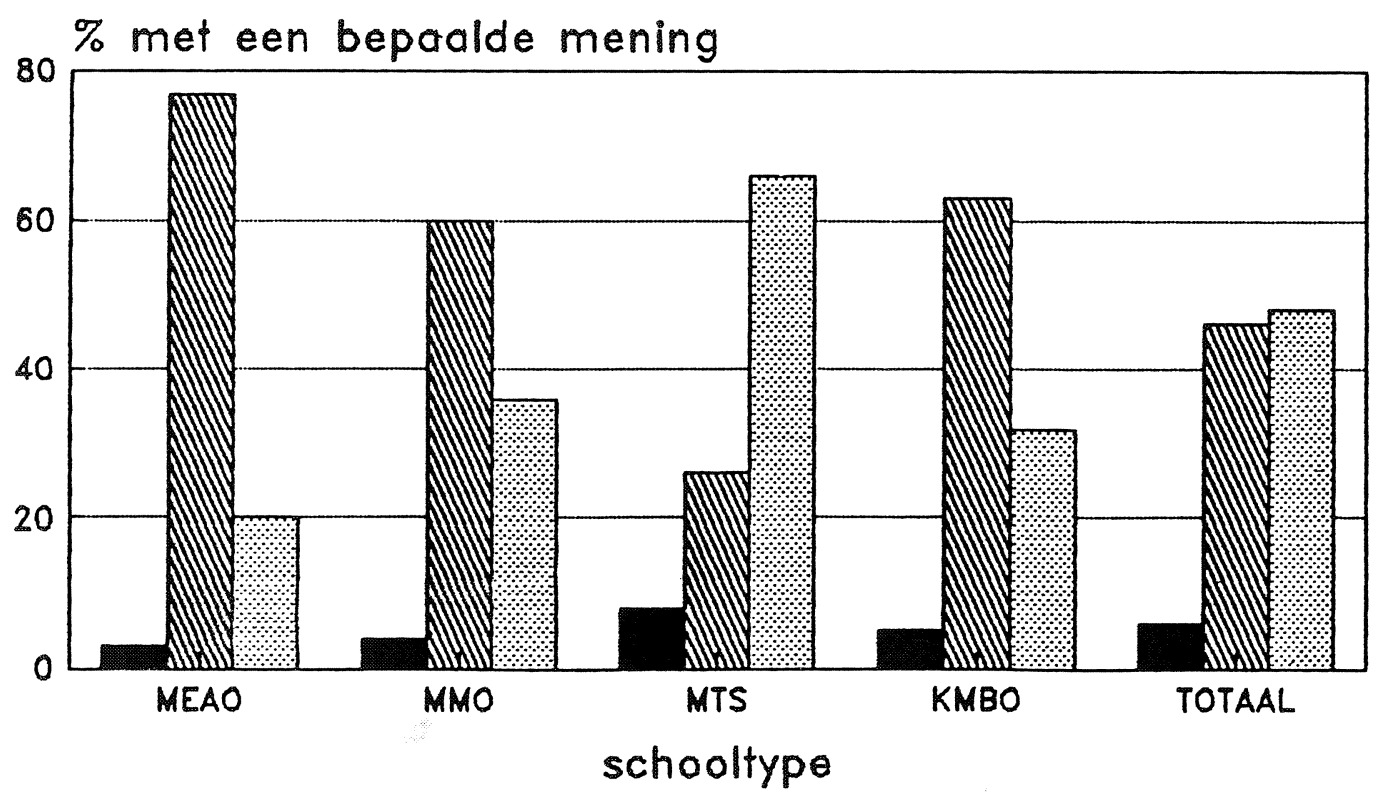

minder stage MIIIV meor stage

Bron: ROA (1989) 
Bijna de helft van de werkende schoolverlaters is van mening dat de totale stageduur aan het (Kort) MBO precies voldoende is geweest, zoals is af te leiden uit figuur 4.IV. Een even grote groep geeft aan dat de stageduur langer zou mogen zijn. Slechts enkelen vinden dat de stages minder lang zouden moeten duren. De verschillen tussen de schooltypen houden direct verband met de verschillen in de totale stageduur tussen de scholen. Aan de MTS volgen de leerlingen gedurende het derde jaar 40 weken stage. De drie andere schooltypen hebben slechts tussen de 6 en 15 weken stage voor hun leerlingen gereserveerd. Van de MTS-ers wil toch nog een kwart van de werkende schoolverlaters een langere stageduur hebben. Van de werkenden van het MMO en KMBO wil maar liefst bijna tweederde en van het MEAO zelfs driekwart een verlenging van de stageduur. 128

Tweederde van de werkenden is van mening dat de stage goed aansluit op de gevolgde opleiding. Voor het MEAO geldt dit zelfs voor bijna driekwart van de werkenden. Daarentegen vindt slechts de helft van de MMO-ers dat de stage goed bij de opleiding heeft gepast. 129

Er blijkt een verband te bestaan tussen de mening over de stageduur en de mening over de aansluiting van de stage op de opleiding. Degenen die de stageplaats niet vinden aansluiten op hun opleiding blijken oververtegenwoordigd te zijn in de groep die meent dat de stageduur verkort kan worden. Omgekeerd zijn deze "ontevredenen" ondervertegenwoordigd in de groep die de stageduur juist zou willen verlengen. 130

Ruim een kwart van de werkenden heeft bij het stagebiedende bedrijf een betaalde baan aangeboden gekregen (zie figuur 4.v.). Daarbij zijn er tussen de schooltypen wel duidelijke verschillen waar te nemen. Terwijl van de werkende MEAO-ers $16 \%$ een betaalde baan door het stagebiedende bedrijf is aangeboden, is dit bij $40 \%$ van de MMO-ers gelukt. Een betaalde functie van MTS-ers is voor ruim een kwart en van werkende KMBO-ers voor bijna een derde deel uit de stage voortgekomen. 131

128. Zie ook tabellenboek, tabe $17 \mathrm{~m}$.

129. Zie ook tabellenboek, tabel 7r.

130. Zie ook tabellenboek, tabel 7v.

131. Zie ook tabellenboek, tabel 7w. 
$\mathrm{Er}$ is dus niet, zoals misschien verwacht zou worden, een positief verband tussen een langere stageduur en het door het stagebiedende bedrijf aanbieden van een betaalde functie. Deels is dit te verklaren door het feit, dat de schoolverlaters niet in het laatste jaar stage lopen. De bedrijven hebben hun voorgaande stagiaires dan waarschijnlijk uit het oog verloren. 132

Figuur 4.V. Percentage werkende schoolverlaters waaraan stagebiedend bedrijf een betaalde baan heeft aangeboden, per schooltype

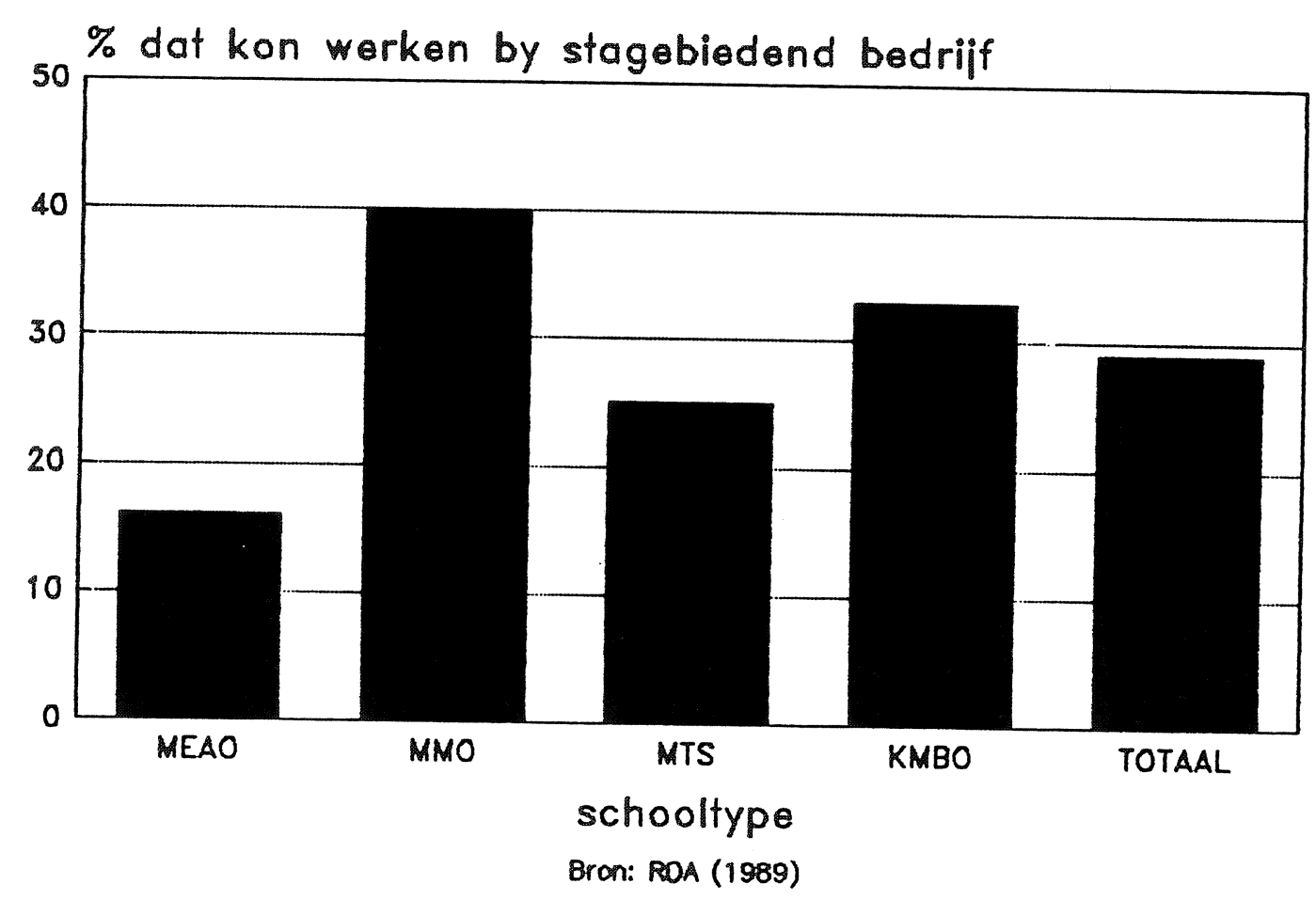

De werkende schoolverlaters uit 1988 is vaker een betaalde baan door het stagebiedende bedrijf aangeboden, dan de werkenden uit het examenjaar 1987. Van de werkende schoolverlaters van 1988 is dit in een derde deel van de gevallen gebeurd, van de overeenkomstige groep uit 1987 slechts in één op de vijf gevallen.133 ook hier zou het interessant zijn op den duur te kunnen vaststellen of hier eventueel sprake is van een trendmatige ontwikkeling.

132. De vraag naar het aanbieden van betaald werk door het stagebiedende bedrijf, gaat niet in op de vraag of en in welke mate werkgevers een (langere) stage laten meewegen in hun wervings- en selectiebeleid.

133. Zie ook tabellenboek, tabel $7 x$. 
4.3. Aanvullende opleidingen en begeleiding

4.3.1. Behoefte_aan_extra kennis en vaardigheden 134

Figuur 4.VI. Percentage werkende schoolverlaters, dat in de huidige functie behoefte heeft aan kennis die niet tijdens de opleiding aan bod is gekomen, per schooltype

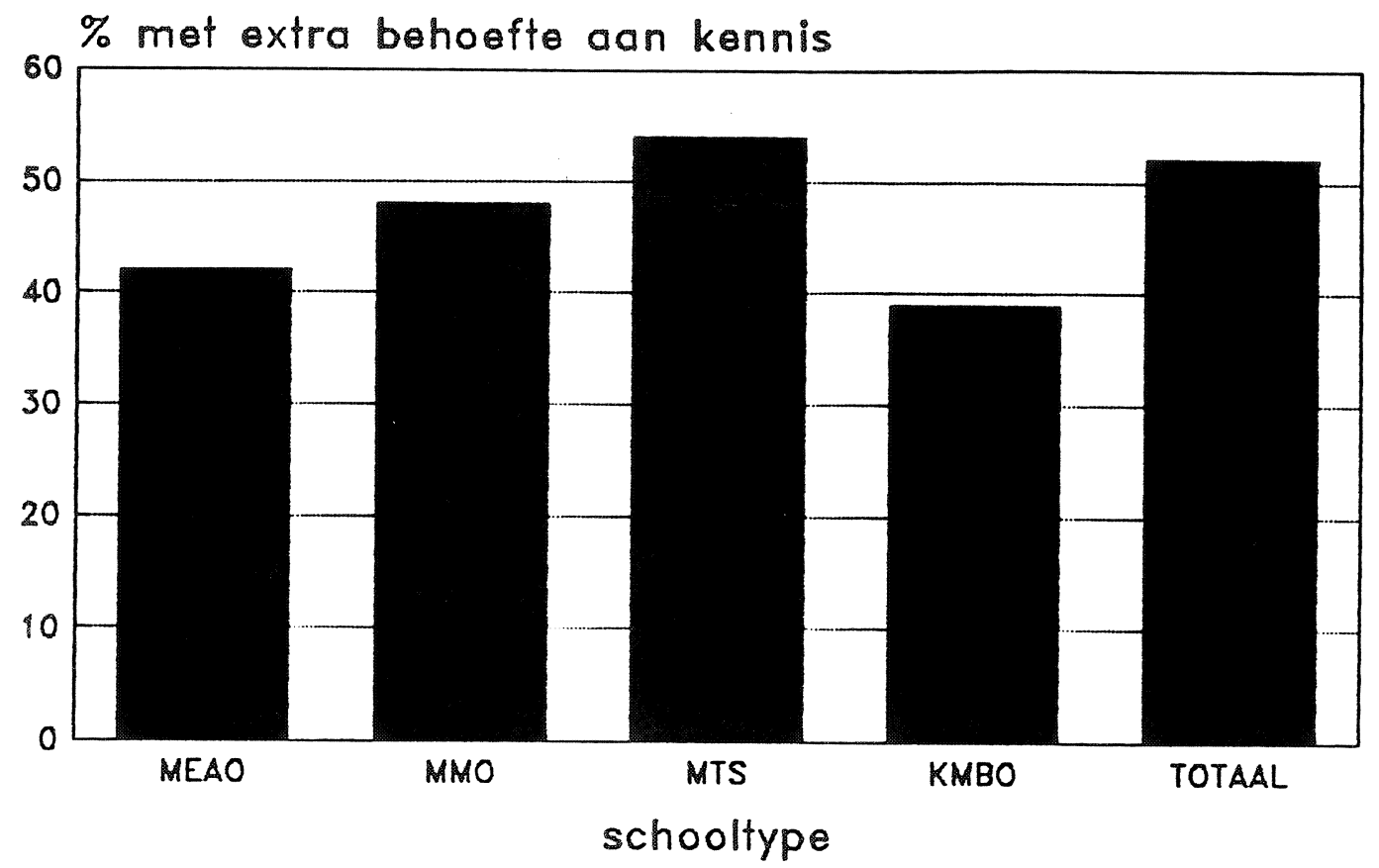

Bron: ROA (1989)

Circa de helft van de werkende schoolverlaters geeft aan dat zij om goed te functioneren in de dagelijkse beroepspraktijk, behoefte hebben aan kennis, die niet aan de opleiding aan bod is gekomen. KMBO-ers blijken met $39 \%$ minder behoefte te hebben aan extra kennis. De verschillen tussen de MBOschooltypen zijn op dit punt marginaal.135 De behoefte aan vaardigheden, die de werkenden tijdens de opleiding niet zijn bijgebracht, is geringer: circa

134. Veel werkende schoolverlaters hebben reeds bij de vraag over de behoefte aan kennis, hun behoefte aan vaardigheden genoemd. Bij de vraag over vaardigheden hebben sommigen onder hen niets ingevuld. Dit betekent dat de behoefte aan kennis dus eigenlijk iets kleiner is dan uit de resultaten blijkt en dat de behoefte aan vaardigheden juist iets groter is dan de resultaten doen vermoeden. Bij het presenteren van de antwoorden over de vraag, aan welke kennis en vaardigheden behoefte bestaat, is het onderscheid tussen kennis en vaardigheden, om bovengenoemde reden, achterwege gelaten.

135. Zie ook tabellenboek, tabel $7 a$. 
43\%. De grootste behoefte is er bij de werkende MMO-ers (48\%), de kleinste bij de KMBO-ers (36\%). 136

Figuur 4.VII. Percentage werkende schoolverlaters, dat in de huidige functie behoefte heeft aan vaardigheden die niet tijdens de opleiding aan bod zijn gekomen, per schooltype

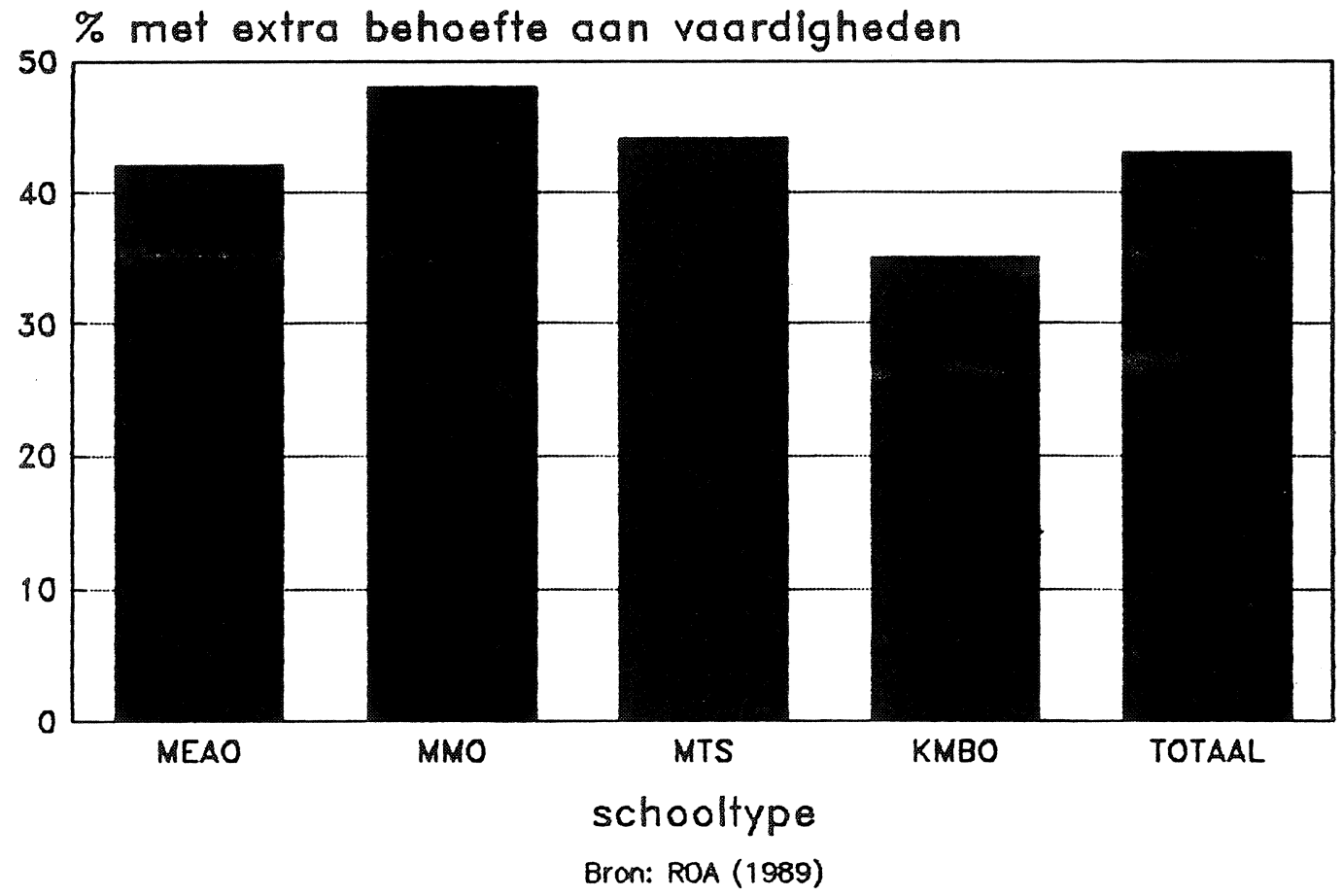

De behoefte aan extra kennis wordt beïnvloed door de periode dat de werkende schoolverlaters reeds full-time werken. Met het toenemen van de werkervaring, neemt de behoefte aan extra kennis af. Terwijl van de werkenden, die tussen de 1 en 3 maanden werkervaring hebben, ruim $70 \%$ behoefte heeft aan extra kennis, heeft van de werkenden met een werkervaring van langer dan een jaar, slechts $44 \%$ hieraan behoefte. 137 Aangenomen mag worden dat het hier gedeeltelijk slechts gaat om aanloopproblemen, die na enige tijd verdwijnen.

Aan welke kennis en vaardigheden, die niet tijdens de (Kort) MBO-opleiding aan bod zijn gekomen, hebben de werkenden, bij de uitoefening van hun huidige functie, behoefte? Deze behoefte is voor de afzonderlijke schooltypen nogal verschillend, zoals te zien is in tabel 4.8., zodat deze behoefte alleen per schooltype wordt aangegeven.

136. Zie ook tabellenboek, tabel $7 \mathrm{~g}$.

137. Zie ook tabellenboek, tabel $7 f$. 
Tabel 4.8. Extra kennis en vaardigheden waaraan schoolverlaters behoefte hebben in de dagelijkse beroepspraktijk, per schooltype, in procenten

\begin{tabular}{lcccc}
\hline SOORT KENNIS/VAARDIGHEDEN & MEAO & MMO & MTS & KMBO \\
& $\%$ & $\%$ & $\%$ & $\%$ \\
\hline Bedrijfskunde, boekhouden & 14 & 24 & 8 & -- \\
Managementvaardigheden & 2 & 12 & 7 & 6 \\
Sociale vaardigheden, mensenkennis & 39 & 24 & 15 & -- \\
Communicatie per telefoon & 11 & 12 & 1 & -- \\
Talenkennis en taalvaardigheden & 2 & -- & -- & 6 \\
Wiskunde en natuurkunde & -- & -- & 1 & 12 \\
Criteria voor (veilig) gebruik van (actuele) materialen, & & & & \\
bewerkingsmethoden en methodiek van werkvoorbereiding & -- & 6 & 15 & 24 \\
Technische tekeningen maken en lezen & -- & -- & 9 & 6 \\
Algemeen technisch inzicht, omgaan met machines & 5 & 12 & 6 & 6 \\
Omgaan met telefax, copier, telex en kassa & 5 & 6 & -- & -- \\
Omgaan met (actuele software van) de computer & 34 & 88 & 27 & 24 \\
Praktische kennis, praktijkervaring, meer stage & 18 & 6 & 16 & 6 \\
Specifieke kennis/vaardigheid m.b.t. bepaald schooltype & 16 & 18 & 56 & 71 \\
Andere kennis of vaardigheden & 5 & 6 & 4 & -- \\
\hline Totaal (abs.) & & & & \\
\hline
\end{tabular}

Bron: ROA (1989)

Veel schoolverlaters blijken behoefte 138 te hebben aan meer kennis van en vooral vaardigheid met de computer in het algemeen en de in de praktijk gebruikte software in het bijzonder. Vooral bij de MMO-ers ligt dit percentage erg hoog. De MEAO-ers en MMO-ers noemen met name tekstverwerkings-, administratie- en boekhoudprogramma's. De MTS-ers willen graag meer weten over bijvoorbeeld CAD/CAM en PLC-besturing. Met name de technisch geschoolden noemen ook vaak zeer specifieke kennis en vaardigheden, die samenhangen met de gespecialiseerde eisen die hun huidige functie stelt. Daarnaast blijkt er grote behoefte te bestaan aan sociale vaardigheden, in welk kader MEAO-ers en MMO-ers eveneens dikwijls de communicatie per telefoon noemen.

138. Bij deze vraag konden de schoolverlaters meerdere antwoorden aankruisen, zodat de som van de percentages van de afzonderlijke antwoordcategorieën meer dan $100 \%$ kan bedragen. Zie ook tabellenboek, tabel 36 a 
Aan praktijkervaring en -kennis blijkt ook veelvuldig behoefte te bestaan. In dit verband kan ook gemeld worden dat een aanzienlijk aantal MTS-ers en KMBO-ers graag zou leren in welke situatie het beste met een bepaald materiaal en/of bewerkingsmethode gewerkt kan worden, waarbij efficiëncy en veiligheid de uitgangspunten zijn. Veel schoolverlaters merken dan ook op, dat men in de dagelijkse praktijk heel anders werkt (of moet werken), dan "op school" is geleerd.139

\subsubsection{Aanvullende cursussen}

Ruim de helft van de werkende schoolverlaters volgt een aanvullende cursus of opleiding naast het werk. Van de werkende MEAO-ers zelfs $62 \%$. Het percentage van de werkenden van de andere schooltypen variëert van $39 \%$ voor het KMBO tot $58 \%$ voor het MMO. De MTS zit daar met 52\% tussenin. 140 Voor bijna al deze aanvullende opleidingen geldt, dat de werkenden hiervoor een diploma kunnen behalen. Alleen de MMO-ers vormen hierop een uitzondering. Voor namelijk $20 \%$ van de werkende MMO-ers bestaat er geen mogelijkheid om een diploma te behalen met de aanvullende cursus die men volgt. 141

Aangezien MEAO-ers en MMO-ers andere soorten cursussen volgen dan MTS-ers en KMBO-ers worden voor deze twee groepen afzonderlijke indelingen gebruikt. MEAO-ers volgen met name cursussen, zoals moderne bedrijfsadministratie, staatspraktijkdiploma (boekhouden), een assurantie- of een bankopleiding. MMO-ers volgen naast hun werk met name marketing-, bank-, commerciële of computerboekhoudcursussen. 142 MTS-ers kiezen hun aanvullende cursussen uit een breder scala aan opleidingen. Veel van de door hen genoemde opleidingen zijn, bedrijfskundige en informatica-opleidingen, meet- en regeltechnieken, PLC-besturingstechnieken en een opleiding tot senior-procesoperator. KMBOers kiezen in het algemeen voor een aanvulling in de metaaltechnieken, zoals cursussen voor onderhoud, lassen, servicetechnicus en transportmiddelentechniek. 143

139. Zie ook tabellenboek, tabel 36a.

140. Zie ook tabellenboek, tabel 6k.

141. Zie ook tabellenboek, tabel $6 n$.

142. Zie ook tabellenboek, tabel 27a.

143. Zie ook tabellenboek, tabel 27k. 
Waarom zijn de schoolverlaters naast hun werk een aanvullende cursus gaan volgen?144 Interesse voor de cursus is bij circa de helft van de werkenden hiervoor een belangrijk motief, zoals blijkt uit tabel 4.9. Ook loopbaanmogelijkheden spelen een rol. De verwachte eisen voor toekomstige functies blijken van groter belang te zijn, dan de eisen die de huidige functie aan hen stelt. Dit geldt in hogere mate voor de werkende cursisten van het MBO, dan van het KMBO. Ofschoon in het algemeen slechts een derde van de werkenden verwacht na de cursus meer te gaan verdienen, zijn het de MMO-ers en vooral de KMBO-ers die op dit punt hoge verwachtingen hebben. Adviezen van het arbeidsbureau spelen nauwelijks een rol bij het al of niet gaan volgen van een bepaalde cursus. Advies van familie en vrienden bij de schoolverlaters van de MBO-opleidingen evenmin. Echter ruim $15 \%$ van de werkende KMBO-ers geeft aan dat het advies van familie of vrienden een motief is geweest om een aanvullende cursus te doen. Het verzoek van de werkgever legt meer gewicht in de schaal. Royaal éénderde van de werkenden noemt dit als motief voor het volgen van een cursus. 145

Tabel 4.9. Motieven voor het volgen van een aanvullende cursus, per schooltype, in procenten

\begin{tabular}{lccccc}
\hline MOTIEVEN & MEAO & MMO & MTS & KMBO & TOTAAL \\
\hline Onvoldoende kennis voor huidige functie & $\%$ & $\%$ & $\%$ & $\%$ & 22 \\
Onvoldoende kennis voor toekomstige functie & 56 & 20 & 43 & 46 & 45 \\
Dan kan ik straks meer gaan verdienen & 33 & 40 & 34 & 54 & 36 \\
Op verzoek van werkgever & 36 & 40 & 37 & 39 & 37 \\
Op advies van familie, vrienden & 5 & -- & 3 & 15 & 4 \\
Op advies van arbeidsbureau & 3 & -- & -- & -- & 1 \\
Uit interesse & 51 & 60 & 48 & 46 & 50 \\
Een ander motief & 5 & -- & 10 & -- & 7 \\
\hline Totaal (abs.) & & & & 13 & 135 \\
\hline
\end{tabular}

Bron: ROA (1989)

144. Bij deze vraag konden de respondenten meerdere antwoorden aankruisen, zodat de som van de percentages van de afzonderlijke antwoordcategorieën meer dan $100 \%$ bedraagt.

145. Zie ook tabellenboek, tabel 16a. 
Wat betreft het verzoek van de werkgever als motief voor het volgen van een cursus is er wel verschil tussen mannen en vrouwen. Terwijl dit motief slechts door een derde deel van de mannen wordt genoemd, vermeldt bijna de helft van de vrouwen deze reden. Daarentegen blijken mannen weer wat meer waarde te hechten aan het feit dat zij straks meer gaan verdienen. Bijna $40 \%$ van de mannelijke werkende schoolverlaters, die een cursus volgen, noemt dit argument tegen slechts $24 \%$ van de vrouwen uit de overeenkomstige groep. 146

Men kan zich afvragen in hoeverre de in paragraaf 4.3.1. beschreven behoefte aan extra kennis of vaardigheden nu samenhangt met het volgen van een aanvullende cursus. Van degenen die naast het werk wel een cursus volgen, blijkt bijna $60 \%$ te hebben aangegeven dat zij extra behoefte hebben aan kennis. Omgekeerd blijkt van de werkenden die geen aanvullende cursus volgen, slechts $41 \%$ behoefte te hebben aan kennis, die in hun opleiding niet aan bod is gekomen. 147 Dit verband blijkt dus aanwezig te zijn.

Gemiddeld $21 \%$ van de werkende schoolverlaters, die een cursus volgen, geeft aan dat de werkgever in het geheel geen medewerking verleent bij het volgen van de cursus. Hoewel de verschillen tussen de schooltypen klein zijn, treft dit in iets hogere mate de MMO-ers. Het geheel of gedeeltelijk betalen van de cursus door de werkgever wordt het meest veelvuldig genoemd door de werkenden die een cursus volgen $(71 \%)$. Ook hier springen de MMO-ers er weer in negatieve zin uit en de MTS-ers in positieve zin (zie tabel 4.10.).

Tabel 4.10. Medewerking van werkgever bij het het volgen van een aanvullende cursus, per schooltype, in procenten

\begin{tabular}{|c|c|c|c|c|c|}
\hline VORM VAN MEDEWERKING & $\begin{array}{c}\text { MEAO } \\
\% \\
\end{array}$ & $\begin{array}{c}\text { MMO } \\
\% \\
\end{array}$ & $\begin{array}{c}\text { MTS } \\
\% \\
\end{array}$ & $\begin{array}{c}\text { KMBO } \\
\% \\
\end{array}$ & $\begin{array}{c}\text { TOTAAL } \\
\% \\
\end{array}$ \\
\hline Geen medewerking & 23 & 27 & 18 & 23 & 21 \\
\hline Werkgever betaalt (mee aan) cursus & 69 & 64 & 74 & 69 & 71 \\
\hline Werkgever geeft vrij voor cursus & 18 & 27 & 28 & 15 & 24 \\
\hline Een andere vorm van medewerking & 3 & 9 & 3 & 8 & 4 \\
\hline Totaal (abs.) & 39 & 11 & 72 & 13 & 135 \\
\hline
\end{tabular}

Bron: ROA (1989)

146. Zie ook tabellenboek, 16d.

147. Zie ook tabellenboek, tabel $8 q$. 
Vrij krijgen voor het volgen van de cursus lukt een veel geringer deel, namelijk slechts bijna een kwart van de werkenden, die een aanvullende cursus doen, waarbij de MTS-ers en de MMO-ers oververtegenwoordigd zijn. 148

Ook de aard van de aanstelling bepaalt de kans op medewerking door de werkgever bij het volgen van een cursus. Terwijl van de werkende cursisten met een vaste aanstelling slechts $20 \%$ geen medewerking van de werkgever krijgt bij het volgen van een cursus, geldt dit in ruim $40 \%$ van de gevallen bij werkende cursisten met een tijdelijke aanstelling. Degenen die een leer-/werkovereenkomst hebben, krijgen (uiteraard) in alle gevallen medewerking van de werkgever. 149

Het inkomen is eveneens gecorreleerd aan de mate waarin de werkgever medewerking verleent bij het volgen van een cursus. Aan de helft van de werkende cursisten, die minder dan 1.000 gulden netto per maand verdienen, verlenen de werkgevers geen enkele vorm van medewerking. Werkende cursisten uit de andere inkomenscategorieën overkomt dit slechts in één op de vijf geval 1en. 150

Het is opvallend dat de werkgevers in de regio Limburg verhoudingsgewijs vaker geen enkele vorm van medewerking verlenen aan de werkende cursisten. Dit betreft de regio's Roermond, Weert, Sittard-Geleen en Ven1o. Terwijl in de andere regio's, op één werkgever na, alle werkende cursisten medewerking ontvangen van hun werkgevers, gebeurt dat in deze regio's in circa een kwart van de gevallen niet. 151

Ook de werkloze en dienstplichtige schoolverlaters is gevraagd of zij na hun opleiding een cursus of andere opleiding hebben gevolgd. Van de schoolverlaters, die op dit moment werkloos zijn, volgt $58 \%$ een aanvullende cursus, waarvoor in alle gevallen een diploma kan worden behaald.152

148. Zie ook tabellenboek, tabel 17a.

149. Zie ook tabellenboek, tabel $17 f$.

150. Zie ook tabellenboek, tabel $17 i$.

151. Zie ook tabellenboek, tabel $17 \mathrm{~h}$.

152. Zie ook tabellenboek, tabel 21. 
Het betreft hier met name MEAO-ers en MMO-ers.153 Dienstplichtigen volgen echter relatief minder vaak aanvullende cursussen. Van deze MBO-ers is na de (Kort) MBO-opleiding een derde een cursus na gaan doen, van de dienstplichtige KMBO-ers zelfs maar $14 \% .154$ Voor deze cursus is vrijwel altijd een diploma te behalen.155 De soort cursus, die werklozen of dienstplichtigen volgen, is overeenkomstig de cursussen die door de werkende schoolverlaters met de betreffende opleiding worden gevolgd.

\subsubsection{Begeleiding door werkgever}

Tabel 4.11. Begeleiding door werkgever bij het inwerken in huidige functie, per schooltype, in procenten

\begin{tabular}{|c|c|c|c|c|c|}
\hline VORM VAN BEGELEIDING & $\begin{array}{c}\text { MEAO } \\
\% \\
\end{array}$ & $\begin{array}{c}\text { MMO } \\
\% \\
\end{array}$ & $\begin{array}{c}\text { MTS } \\
\% \\
\end{array}$ & $\begin{array}{c}\text { KMBO } \\
\% \\
\end{array}$ & $\begin{array}{c}\text { TOTAAL } \\
\% \\
\end{array}$ \\
\hline Zonder hulp begonnen & 10 & 28 & 21 & 18 & 18 \\
\hline Vooraf bedrijfstrainig of -cursus & 10 & 11 & 18 & 9 & 14 \\
\hline Ingewerkt door collega's & 89 & 67 & 75 & 76 & 78 \\
\hline Een andere vorm van begeleiding & 2 & 22 & 6 & 6 & 6 \\
\hline Totaal (abs.) & 39 & 11 & 72 & 13 & 135 \\
\hline
\end{tabular}

Bron: ROA (1989)

Zoals tabel 4.11. laat zien, merkt gemiddeld $78 \%$ van de werkende schoolverlaters op dat zij bij de aanvang van de huidige functie door collega's is ingewerkt. 156 Van de MEAO-ers is zelfs $89 \%$ door collega's ingewerkt, terwijl van de werkende MMO-ers slechts tweederde op deze wijze zijn begeleid.

MMO-ers zijn het vaakst zonder enige hulp beginnen te werken $(28 \%)$. Voor de werkzame MTS-ers en KMBO-ers is dit percentage circa $20 \%$ en voor de werkende schoolverlaters met een MEAO-opleiding $10 \%$.

153. Zie ook tabellenboek, tabel $2 k$.

154. Zie ook tabellenboek, tabel $4 a$.

155. Zie ook tabellenboek, tabel $4 \mathrm{~b}$.

156. Bij deze vraag konden de respondenten meerdere antwoorden aankruisen. Om deze reden bedraagt de som van de percentages van de afzonderlijke antwoorden meer dan $100 \%$. 
Bedrijfstrainingen of cursussen voór of direct bij aanvang van de functievervulling worden vaker door MTS-ers genoemd. 157

Er bestaat een opmerkelijk verband tussen de soort begeleiding bij de aanvang van de functie en de totale stageduur die de schoolverlater tijdens de (Kort) MBO-opleiding heeft genoten. Bij toename van het aantal stageweken neemt het percentage van de werkende schoolverlaters dat ingewerkt wordt door collega's af. Omgekeerd neemt het percentage van de werkenden die zonder hulp meteen alle werkzaamheden hebben vervuld toe bij het stijgen van de stageduur. Dit laatste geldt ook voor het percentage dat vooraf een bedrijfstraining of -cursus heeft gevolgd. 158 Kennelijk heeft de stageperiode hier reeds enigszins als een inwerkperiode gefunctioneerd. Het bedrijfsleven zou hiermee rekening kunnen houden bij de afweging van de baten en lasten van stageplaatsen.

Ook de soort aanstelling is van invloed op de begeleiding door de werkgever bij aanvang van de functie. Terwij1 van de werkenden met een vaste aanstelling ruim $80 \%$ door collega's is ingewerkt geldt voor werkenden met een tijdelijke aanstelling slechts een percentage van bijna $70 \%$. Daarentegen moeten tijdelijk werkenden in een kwart van de gevallen zonder hulp meteen alle werkzaamheden uitvoeren, tegenover mensen met een vaste betrekking slechts in één op de zes gevallen. De begeleiding van de schoolverlaters met een leer-/werkovereenkomst staat vanzelfsprekend geheel in het teken van de bedrijfsopleiding. 159

In dit kader kan nog worden opgemerkt dat, degenen die hun huidige functie via tijdelijk werk (c.q. het uitzendbureau) hebben verworven, voor ruim een derde deel zonder hulp meteen alle werkzaamheden hebben vervuld. Voor de overige mogelijkheden van het vinden van werk is dit maximaal een vierde dee1.160 Voor degenen die via tijdelijk werk inmiddels een vaste baan hebben gevonden wijst dit erop dat ook tijdelijk werk blijkt te fungeren als een inwerkperiode. Doch degenen die via het uitzendbureau (nog) een tijdelijke functie hebben, worden mogelijk niet ingewerkt door collega's óf doordat

157. Zie ook tabellenboek, tabel 15a.

158. Zie ook tabellenboek, tabel 15e.

159. Zie ook tabellenboek, tabel 15f.

160. Zie ook tabellenboek, tabel $15 \mathrm{~g}$. 
werkgevers dit niet relevant vinden óf doordat de collega's zelf ook tijdelijke krachten zijn.

Bij een vergelijking van de begeleiding door de werkgever met de regio, waar deze werkgever is gelokaliseerd, valt op dat in Midden-Limburg weinig gebruik wordt gemaakt van bedrijfstrainingen of cursussen bij het inwerken van de schoolverlaters in vergelijking met de andere regio's. Daar staat tegenover dat in ruim $80 \%$ van de gevallen de werkenden uit Midden- (en Noord-) Limburg door collega's worden ingewerkt. 161 


\section{CONCLUSIES}

\subsection{Inleiding}

In dit hoofdstuk worden conclusies getrokken naar aanleiding van de belangrijkste onderzoeksresultaten. De door ons gehouden schoolverlatersenquête heeft, zoals gezegd, betrekking op de volgende onderzoekspopulatie en probleemstelling.

De onderzoekspopulatie kan worden omschreven als alle gediplomeerde schoolverlaters uit de examenjaren 1987 en 1988 van de voltijdse opleidingen van het MEAO (m.u.v. de secretariaatsrichting), het MMO-C (inclusief de groothandelsrichting), de MTS en het KMBO-Metaaltechnieken in Midden-Limburg (i.c. Roermond/Heythuysen).

De probleemstelling van het onderzoek omvat een tweetal vragen:

- welke verschillen bestaan er tussen de betreffende schoolverlaters in hun arbeidsmarktpositie?;

- welke verschillen bestaan er tussen de betreffende schoolverlaters met betrekking tot de aansluiting van de door hen gevolgde opleiding op hun huidige (start) functie?

Bij de analyse en de rapportage van de beide deelaspecten van de probleemstelling hebben de verschillen tussen de schooltypen centraal gestaan.162 Daarnaast is er aandacht besteed aan eventuele verschilien tussen de schoolverlaters die kunnen voortvloeien uit de verschillen in examenjaar en achtergrondkenmerken. Bij de resultaten van de gehouden enquête dient men in het oog te houden, dat het hier gat om schoolverlaters die respectievelijk circa tien en tweeëntwintig maanden van school af zijn. De functies die deze schoolverlaters bezetten kunnen dan ook veelal getypeerd worden als startfuncties.

In paragraaf 5.2. worden nog eens in het kort de belangrijkste verschillen tussen de schooltypen en de examenjaren wat betreft de toetreding tot de arbeidsmarkt en de arbeidsmarktpositie van de schoolverlaters uiteengezet. Daarna wordt in paragraaf 5.3. ingegaan op de resultaten met betrekking tot

162. Gezien de oververtegenwoordiging van de MTS in de totale onderzoekspopulatie is het niet zinvol om de resultaten van de totale onderzoekspopulatie als uitgangspunt te nemen. 
de kwalitatieve aansluiting tussen de (Kort) MBO-opleiding en de werksituatie. Vervolgens wordt in paragraaf 5.4. een overzicht gegeven van de mogelijke achterliggende factoren, die verantwoordelijk zijn voor de verschillen in de arbeidsmarktpositie tussen de schoolverlaters van de diverse (Kort) MBO-opleidingen. In paragraaf 5.5. volgen enkele suggesties voor eventuele aanpassingen van de (Kort) MBO-opleidingen en mogelijkheden voor werkgevers om de aansluiting naar de arbeidsmarkt te verbeteren. Het hoofdstuk wordt besloten met enkele ideeën voor een follow-up van deze schoolverlatersenquête.

\subsection{De arbeidsmarktpositie van de schoolverlaters}

\subsubsection{Toetreding tot de de_arbeidsmarkt}

Tabel 5.1. Activiteiten nadat (Kort) MB0-opleiding een half jaar is verlaten, per schooltype, gedifferentieerd naar examenjaar, in procenten

\begin{tabular}{|c|c|c|c|c|c|c|c|c|}
\hline \multirow{2}{*}{$\begin{array}{l}\text { SCHOOLTYPE } \\
\text { EXAMENJAAR }\end{array}$} & \multicolumn{2}{|c|}{ MEAO } & \multicolumn{2}{|c|}{ MMO } & \multicolumn{2}{|c|}{ MTS } & \multicolumn{2}{|c|}{ KMBO } \\
\hline & ' 87 & ' 88 & ' 87 & ' 88 & ' 87 & $' 88$ & $' 87$ & ' 88 \\
\hline ACT IVITEI TEN & $\%$ & $\%$ & $\%$ & $\%$ & $\%$ & $\%$ & $\%$ & $\%$ \\
\hline Betaald werk & 61 & 35 & 58 & 35 & 44 & 40 & 76 & 74 \\
\hline Werkloos & 15 & 6 & 8 & 6 & 5 & 4 & 10 & 6 \\
\hline Dagonderwijs & 18 & 45 & 27 & 52 & 42 & 42 & 5 & 16 \\
\hline Dienstpl icht & 6 & 14 & 8 & 6 & 10 & 14 & 10 & 3 \\
\hline Totaal (\%) & 100 & 100 & 100 & 100 & 100 & 100 & 100 & 100 \\
\hline Totaal (abs.) & 68 & 69 & 26 & 31 & 193 & 175 & 21 & 31 \\
\hline
\end{tabular}

Bron: ROA (1989)

Ten tijde van het afnemen van de enquête blijken er grote verschillen te bestaan in de mate warin de schoolverlaters van de vier onderzochte schooltypen tot de arbeidsmarkt zijn toegetreden. De verschillen treden overigens ook een half jaar na het verlaten van het (Kort) MBO reeds op, zoals blijkt uit tabel 5.1 . 
De KMBO-ers163 zijn vaker toegetreden tot de arbeidsmarkt, dan de oudleerlingen van het MBO, die vaker hebben gekozen voor vervolgopleidingen in het dagonderwijs.

Maar ook tussen de schoolverlaters uit 1987 en 1988 zijn er op dit punt verschillen waarneembaar. Voor met name de MEAO-ers is de werkloosheid, een half jaar na het verlaten van het (Kort) MBO, tussen 1987 en 1988 fors gedaald. Tevens is er bij het MEAO en het MMO tussen de twee examenjaren een belangrijke verschuiving waar te nemen in de bestemming van de schoolverlaters. Hier is sprake van een dalende toetreding tot de arbeidsmarkt, die gepaard gaat met een toenemende doorstroming naar vervolgopleidingen in het dagonderwijs (zie ook tabel 5.1.).

Bovendien blijken leeftijd, geslacht, vooropleiding, doubleren aan het MBO en de opleiding van de ouders verklarende factoren te zijn voor de verschillen in de huidige situatie van de schoolverlaters. Oudere, evenals vrouwelijke schoolverlaters, schoolverlaters met LBO als vooropleiding, schoolverlaters die aan het MBO hebben gedoubleerd en schoolverlaters waarvan de ouders een lagere opleiding hebben genoten blijken vaker voor betaald werk te kiezen. Daarentegen kiezen jongere, evenals mannelijke schoolverlaters, schoolverlaters met een HAVO-vooropleiding, schoolverlaters die niet hebben gedoubleerd aan het MBO en schoolverlaters waarvan de ouders een hogere opleiding hebben, vaker voor een vervolgopleiding.

Schoolverlaters die bij de keuze van de opleidingsrichting aan het (Kort) MBO rekening hebben gehouden met de kans op werk die zij met een bepaalde opleiding hebben, zijn ook vaker gaan werken. Omgekeerd hebben degenen, die deze keuze (nog) niet hebben laten beïnvloeden door arbeidsmarktperspectieven vaker voor vervolgonderwijs gekozen.

\subsubsection{Vers}

Op grond van de probleemstelling van dit onderzoek is bij de bespreking van de arbeidsmarktpositie van de schoolverlaters de meeste aandacht besteed aan de werkende schoolverlaters.

163. Circa $17 \%$ van de KMBO-ers, die betaald werk verrichten, hebben een baan in het kader van het leerlingwezen. KMBO-ers blijken zich dus vaker verder te scholen in combinatie met betaalde arbeid. 
In deze subparagraaf wordt voor ieder schooltype afzonderlijk daarom alleen van deze werkenden de arbeidsmarktpositie geschetst.

MEAO

Bijna driekwart van de werkende MEAO-ers heeft een vaste en ruim een kwart een tijdelijke aanstelling. Het overgrote deel (91\%) werkt contractueel 36 $\mathrm{t} / \mathrm{m} 40$ uur per week (ruim $60 \%$ werkt wel eens over) en slechts $3 \%$ heeft een onregelmatige dienst. Inmiddels heeft ruim een kwart van de MEAO-ers reeds bij twee of drie werkgevers gewerkt.

Ruim $85 \%$ heeft een functie die qua richting overeenstemt met de gevolgde opleiding, de werkzaamheden zijn echter nogal eens routinematig en meestal van een laag niveau. Eén op de drie MEAO-ers heeft een baan als administrateur, c.q. (assistent) boekhouder. Gemiddeld verdienen de MEAO-ers zo'n $1.390,--$ gulden netto per maand.

Bijna de helft heeft een baan in de bedrijfssector van de zakelijke dienstverlening en ongeveer een kwart werkt in de industriële sector. De helft van de werkende MEAO-ers is werkzaam in het kleinbedrijf, een derde deel in het midden-bedrijf. Het overgrote deel (83\%) werkt in de regio Midden-Limburg, waarvan $72 \%$ in de regio Roermond.

MMO

Slechts tweederde van de werkende MMO-ers heeft een vaste betrekking, een kwart van hen heeft tijdelijk werk en $8 \%$ werkt in het kader van het leerlingwezen. Niet meer dan $79 \%$ van de werkende MMO-ers heeft een werkweek van $36 \mathrm{t} / \mathrm{m} 40$ uur, de resterende $22 \%$ werkt in deeltijd. Veel MMO-ers ( $89 \%)$ doen geregeld overwerk en $11 \%$ werkt in een ploegen- of onregelmatige dienst. De MMO-ers hebben na het verlaten van het MMO over het algemeen bij meer dan één werkgever gewerkt; tweederde is inmiddels al bij twee of drie werkgevers in dienst geweest.

Ongeveer $60 \%$ van de MMO-ers heeft een functie die qua richting aansluit bij de gevolgde MMO-opleiding. Aan de ene kant betreft het vaak laag gekwalificeerde en routinematige werkzaamheden. Bijvoorbeeld in administratieve functies, waarin $65 \%$ werkzaam is. Bovendien heeft een kwart van de MMO-ers heeft een laag gekwalificeerde functie als winkel-, of magazijnmedewerker. 
Aan de andere kant vervult $20 \%$ reeds een beroep met een behoorlijk hoog functieniveau, zoals bedrijfsleider of handelsvertegenwoordiger. De MMO-ers verdienen netto per maand gemiddeld $1.355,--$ gulden.

De helft van de MMO-ers is werkzaam in de handel, $20 \%$ in de zakelijke dienstverlening en eveneens $20 \%$ in de industriële sector. De helft werkt in het kleinbedrijf, tegenover $37 \%$ in het midden-bedrijf. Slechts $56 \%$ werkt in Midden-Limburg, waarvan de helft in de regio Roermond, de andere helft in de regio Weert.

\section{$\underline{\text { MTS }}$}

Ruim driekwart van de werkende MTS-ers heeft een vaste aanstelling. Circa $87 \%$ heeft een werkweek van $36 \mathrm{t} / \mathrm{m} 40$ uur (en bijna $70 \%$ werkt wel eens over). Van de MTS-ers is $13 \%$ werkzaam in een ploegen- of onregelmatige dienst. Eénderde van de MTS-ers heeft inmiddels bij twee of drie werkgevers gewerkt.

Bijna aile MTS-ers vervullen een functie die wat betreft richting past bij de gevolgde opleiding. Wat betreft het niveau van de werkzaamheden kan worden opgemerkt dat een kwart van de MTS-ers eenzelfde functie heeft als KMBO-ers-Metaaltechnieken, zoals machinebankwerker of procesarbeider. Merendeels zijn dit MTS-ers uit het examenjaar 1988. Daarnaast is $17 \%$ van de MTS-ers werkzaam als technisch tekenaar.

De helft van de MTS-ers werkt in de industrie, $19 \%$ in de bouw en $10 \%$ op een ingenieurs- of architectenbureau. Slechts $19 \%$ heeft een werkgever in het kleinbedrijf, $39 \%$ daarentegen in het grootbedrijf. In de regio MiddenLimburg is $59 \%$ werkzaam, waarvan $78 \%$ in Roermond en omstreken.

De MTS-ers, die meestal iets ouder zijn, verdienen met gemiddeld $1.625,--$ gulden netto per maand meer dan de schoolverlaters van de andere hier onderzochte opleidingscategorieën.

\section{KMBO}

Bijna driekwart van de werkende KMBO-ers heeft een vaste betrekking; tijdelijk werk doet slechts $11 \%$. Relatief veel (17\%) KMBO-ers hebben een leer-/werkcontract in het kader van het leerlingwezen. Bijna $80 \%$ werkt tussen de 36 en 40 uur per week. 
Ruim $15 \%$ werkt in een ploegen- of onregelmatige dienst (en ruim driekwart van de KMBO-ers maakt geregeld overuren). Na het verlaten van het KMBO heeft slechts ruim een kwart bij meer dan één werkgever gewerkt.

Ongeveer $85 \%$ van de werkende KMBO-ers heeft een baan gevonden die aansluit bij de opleiding Metaaltechnieken aan het KMBO. Zo is ruim de helft machinebankwerker/metaalbewerker en bijna een derde lasser/constructie-, c.q. plaatwerker.

Bijna alle KMBO-ers werken in de industrie, namelijk 93\%, waarvan $70 \%$ in de metaal- of machine- en transportmiddelenindustrie en $20 \%$ in de chemische, rubber- en kunststofindustrie. Het overgrote deel van de KMBO-ers (90\%) werkt in het midden- of kleinbedrijf. Slechts $51 \%$ van de KMBO-ers is werkzaam in Midden-Limburg, waarvan $82 \%$ in de regio Roermond. Meer dan een kwart van de KMBO-ers blijkt in de regio Sittard-Geleen te werken.

Met gemiddeld $1.215,--$ gulden netto per maand verdienen de, over het algemeen verhoudingsgewijs jonge, KMBO-ers het minste van de vier onderzochte opleidingscategorieën. Voor een deel kan dit relatief lage inkomen ook het gevolg zijn van de relatief grote groep die een arbeidsleercontract heeft in het kader van het leerlingwezen.

Wanneer men de verschillen tussen de schooltypen bekijkt, kan men (voorzichtig) concluderen, dat, vanuit de optiek van de schoolverlaters, de werkende MMO-ers de minst goede arbeidsmarktpositie hebben, gevolgd door de KMBO-ers en de MEAO-ers en dat de MTS-ers het beste arbeidsmarktperspectief genieten.

\subsubsection{Verschillen tussen de examenjaren 1987 en 1988}

Naast verschillen tussen de schooltypen bestaan er wat betreft de arbeidsmarktpositie van de werkende schoolverlaters verschillen tussen de schoolverlaters van 1987 en 1988. De schoolverlaters uit 1988 blijken minder vaak een vaste en vaker een tijdelijke betrekking te hebben, alsmede een kortere werkweek dan de werkenden uit 1987. Hoewel de schoolverlaters uit 1987 reeds een jaar langer van het (Kort) MBO af zijn, hebben de degenen die in 1987 de school verlieten nauwelijks bij meer werkgevers gewerkt, dan de oud-leerlingen uit 1988. Bovendien blijkt de lichting uit 1987 vaker bij grotere bedrijven te werken. 
Daarnaast is er tussen 1987 en 1988 binnen de regio Midden-Limburg een verschuiving te constateren van werkgevers richting de regio Weert.

Ook zijn er tussen de twee examenjaren verschillen waar te nemen in de huidige functies van de schoolverlaters, zowel wat betreft de richting als het niveau van de werkzaamheden. Van de MEAO-ers en MMO-ers uit 1987 heeft een veel groter deel een functie als administrateur/boekhoudkundige, terwijl onder de corresponderende groep uit 1988 veel meer bankemployées, kassières en voorraadaanvullers te vinden zijn. Van de MTS-ers en KMBO-ers uit 1988 is een groter deel machinebankwerker/metaalbewerker of lasser, terwijl van de technisch geschoolden uit 1987 een groter deel een functie heeft als technisch tekenaar of technicus. Het werk van de schoolverlaters uit 1987 heeft dus over het algemeen een hoger functieniveau. Tenslotte blijken de werkenden uit 1987 netto per maand gemiddeld 170 gulden meer te verdienen.

\subsection{De kwalitatieve aansluiting tussen opleiding en arbeidsmarkt}

\subsubsection{De a aansluitting tússen_opleiding en functie in het algemeen}

Ruim tweederde van de werkenden is van mening dat de huidige werkzaamheden aansluiten bij de door hen gevolgde (Kort) MBO-opleiding. De percentages variëren van $39 \%$ voor het MMO tot $75 \%$ voor het MEAO. Van de werkende MTS-ers en KMBO-ers vindt respectievelijk $71 \%$ en $66 \%$ dat de huidige functie aansluit bij de betreffende opleiding. Van de schoolverlaters uit 1987 deelt $74 \%$ deze mening, tegenover $62 \%$ van de schoolverlaters uit 1988.

Deze verschillen tussen de schooltypen en de beide examenjaren komen overeen met de verschillen die zijn geconstateerd bij de arbeidsmarktpositie, in die zin dat van de laatst afgestudeerde groep de vervulde functies minder goed lijken aan te sluiten bij de genoten opleiding. De arbeidsmarktpositie en de mening over de aansluiting van de gevolgde (Kort) MBO-opleiding op de huidige functie blijken dus nauw met elkaar samen te hangen.

\subsubsection{Beoordeling van de (Kort) MBO-opleiding}

Zowel de aandacht voor de theoretisch-technische vakken als de actualiteit van deze vakken worden door een ruime meerderheid van de schoolverlaters als voldoende beoordeeld (respectievelijk $75 \%$ en $67 \%$ ). 
De technisch geschoolden echter, met name de MTS-ers, vinden de aandacht voor en de actualiteit van het vak computerkunde (zeer) vaak onder de maat, hoewel zij dit vak minder vaak nodig zeggen te hebben dan de MEAO-ers en MMO-ers. De MEAO-ers maken over het algemeen minder gebruik van de in hun opleiding gevolgde vakken, dan de werkenden van de drie overige schooltypen $(30 \%$ versus circa $50 \%)$.

Het oefenen met diverse praktijkonderdelen wordt het minst door de MMO-ers en het meest door de KMBO-ers als voldoende beoordeeld. Volgens de schoolverlaters, de MEAO-ers uitgezonderd, is er met name te weinig geoefend met actuele software-pakketten. Over de actualiteit van de praktijkonderdelen denken de MTS-ers het vaakst negatief. MEAO-ers hebben vaker apparatuur en machines en vooral software in hun huidige functie nodig, de technisch geschoolden gebruiken daarentegen met name materiaal en gereedschap en in iets mindere mate apparatuur en machines. Gemiddeld blijken de MM0-ers in de beroepspraktijk het minste gebruik te maken van de in hun opleiding aangeboden praktijkonderdelen.

Wat betreft de taalvaardigheden kan worden opgemerkt, dat meestal de schriftelijke taalvaardigheid beter wordt beoordeeld dan de mondelinge, met uitzondering van het vak Nederlands aan het KMBO. Ruim een derde deel gebruikt de talen dagelijks in het werk. Van de MMO-ers echter ruim $75 \%$. De MEAO-ers en MMO-ers beoordelen de aandacht voor de mondelinge en schriftelijke taalvaardigheden vaker positief dan de technisch geschoolden.

Bijna de helft van de werkenden vindt de stageduur precies voldoende, de andere helft vindt dat de stage langer had moeten duren (zie figuur 4.II). De verschillen in de gewenste stageduur tussen de schooltypen houden direct verband met de verschillen in de feitelijke stageduur, in die zin dat degenen die verhoudingsgewijs een lange stageduur hebben, zoals de MTS-ers, minder vaak de stage(s) willen verlengen. Tweederde van de werkenden vindt de stage aansluiten bij de opleiding. Een kwart van de werkenden kon zelfs een baan krijgen, in het bedrijf waar ze stage liepen. Degenen die veel langer dan gemiddeld stage hebben gelopen, zoals de MTS-ers, kunnen niet vaker een betaalde baan bij het stagebiedende bedrijf bemachtigen. 


\subsubsection{Aanvull lende_opleidingen en begeleiding}

Circa de helft van de werkenden heeft in de huidige functie behoefte aan extra kennis en/of vaardigheden, die niet tijdens de (Kort) MBO-opleiding aan bod zijn gekomen. De schoolverlaters noemen daarbij met name kennis en vaardigheden met betrekking tot automatisering, sociale vaardigheden en schoolspecifieke kennis of vaardigheden. De behoefte aan sociale vaardigheden, die opvallend genoeg ook door de technisch geschoolden wordt gevoeld, betreft het omgaan met collega's, de chef of de baas, maar ook (telefonische) contacten met klanten of opdrachtgevers.

Opmerkelijk is dat deze behoefte met het toenemen van de werkervaring blijkt af te nemen. Bovendien blijkt de behoefte aan extra kennis en vaardigheden een positief verband te hebben met het volgen van een aanvullende cursus. Ruim de helft van de werkenden volgt naast het werk een cursus. Naast de interesse voor een cursus blijkt het verbeteren van loopbaanmogelijkheden een belangrijke drijfveer voor het volgen van een aanvullende cursus. Ook een direct verzoek van de werkgever is een belangrijk motief voor het gaan volgen van een cursus. Circa $70 \%$ van de werkgevers betaalt (een deel van) de cursuskosten en bijna een kwart geeft (bovendien) vrij voor het volgen van de cursus. Daar staat tegenover dat $20 \%$ van de werkgevers geen enkele medewerking verleent aan de bij hen werkende schoolverlaters die een loopbaangerichte cursus volgen.

Bovendien hebben nogal wat schoolverlaters bij de aanvang van hun huidige functie enige begeleiding gekregen. Ruim driekwart van de werkenden is ingewerkt door collega's. Daarentegen is bijna $20 \%$ zonder enige hulp aan de huidige werkzaamheden begonnen, waarbij de percentages variëren van $10 \%$ voor het MEAO tot maar 1 iefst $28 \%$ voor het MMO.

\subsection{Arbeidsmarktfactoren}

Welke factoren liggen nu ten grondslag aan de geconstateerde verschillen in de positie en de aansluiting op de arbeidsmarkt van de schoolverlaters tussen enerzijds de schooltypen en anderzijds de beide examenjaren?

De verschillen tussen de schooltypen kunnen voor een belangrijk deel worden verklaard door de verschillen tussen vraag en aanbod van bepaalde groepen 
schoolverlaters. Deze verschillen uiten zich deels kwantitatief, bijvoorbeeld in het werkloosheidspercentage, deels kwalitatief, waarbij het gaat om het soort werk waarvoor deze schoolverlaters worden gevraagd (w.0. de aard van de werkzaamheden en de arbeidsvoorwaarden).

Naar aanleiding van de resultaten van de geraadpleegde schoolverlatersenquête, de hierin gemaakte opmerkingen van respondenten en literatuur, kan worden geconstateerd dat ook de meningsvorming onder werkgevers ten aanzien van een bepaalde opleiding een belangrijke rol speelt bij de arbeidsmarktperspectieven van de schoolverlaters van de desbetreffende opleiding. Zo geven MMO-ers in de enquête regelmatig te kennen, dat zij merken dat de werkgevers weinig weten van de MMO-opleiding of dat werkgevers denken dat MMO-ers slechts inzetbaar zijn als winkelhulp in de detailhandel. MEAO-ers daarentegen worden hoger ingeschat, waardoor zij ook de MMO-ers verdringen uit de beroepsdomeinen waarop het MMO zich richt. Werkgevers beschouwen KMBO-ers met een opleiding in de Metaaltechnieken niet als MTS-ers, maar veeleer als LTS-ers; derhalve worden KMBO-ers slechts ingezet voor uitvoerend productiewerk, terwijl het grootste gedeelte van de MTS-ers in de productie-voorbereidende sfeer werkt.

Zoals hierboven reeds is aangegeven hebben de werkende schoolverlaters uit 1987 in het algemeen een betere arbeidsmarktpositie, dan de werkenden uit 1988. De oorzaak hiervan kan zijn, dat schoolverlaters pas na verloop van tijd doorstromen naar hoger gekwalificeerde banen met betere arbeidsvoorwaarden. Daarentegen is het ook goed mogelijk dat er voor de schoolverlaters uit 1988 minder goede banen voorhanden zijn geweest. Met andere woorden, dat de markt verzadigd is voor de beroepssectoren, waarvoor deze schoolverlaters worden opgeleid. Hiermee hangt direct het in paragraaf 1.1 . beschreven verschijnsel onderbenutting samen. Door het grote aanbod van arbeid kunnen de werkgevers hogere functie-eisen stellen. Zo verdringen HBO-ers mogelijk de MBO-ers uit de functies die voorheen vervuld werden door MBO-ers. Op hun beurt nemen MBO-ers op de arbeidsmarkt de plaats in van LBO-ers en Kort-MBOers. Verdringing vindt bovendien niet alleen verticaal plaats tussen onderwijsniveaus, maar ook horizontaal tussen verschillende opleidingsrichtingen, zoals reeds geconstateerd is tussen het MMO en het MEAO.

Uit de enquête is gebleken, dat de werkenden uit 1987 nauwelijks bij meer werkgevers hebben gewerkt, dan de werkenden uit 1988, die zich toch veel minder lang op de arbeidsmarkt bevinden. De schoolverlaters uit 1988 hebben 
derhalve sneller van werkgever gewisseld. Dit vormt een indicatie voor een toenemende zoekactiviteit op de arbeidsmarkt door de schoolverlaters en mogelijk ook voor de toenemende betekenis van verdringingsprocessen.

Daarnaast is dit een aanwijzing voor een toenemende flexibilisering van de arbeidsmarkt, welke zich uit in een groeiend belang van tijdelijke arbeidscontracten al dan niet via uitzendwerk. De schoolverlater blijkt in ieder geval (enige tijd) genoegen te moeten nemen met laag gekwalificeerd werk met een tijdelijk karakter.

Daarnaast is het mogelijk dat werkgevers schoolverlaters niet alleen voor een bepaalde functie werven, maar juist voor een loopbaan binnen het bedrijf. Veel schoolverlaters zullen op deze wijze eerst werk onder hun niveau moeten aanpakken, alvorens zij, eventueel aangevuld met een (interne) opleiding, kunnen doorstromen naar hoger gekwalificeerde functies in het bedrijf. Dit proces van interne arbeidsmarkten heeft vooral betrekking op de grote bedrijven en zou met name van toepassing kunnen zijn op de MTS-ers.

Opvallend is ook de toename van het aantal schoolverlaters dat na de MBOopleiding nog verder doorleert. Dit proces, dat overigens deels het gevolg kan zijn van een onvrede over het functieniveau waarin MBO-schoolverlaters (enige tijd) werkzaam (moeten) zijn, heeft als gevolg dat de gediplomeerde MBO-ers niet direct toetreden tot de arbeidsmarkt. Dit zal er toe leiden dat de problemen rondom het vervullen van vacatures, waarvoor MBO-ers worden gevraagd, toenemen.

\subsection{Beleidsimplicaties}

\subsubsection{Voorstellen voor aanpassing van de (Kort) MBO-opleiding}

Wat zijn nu de beleidsimplicaties van dit enquête-onderzoek ten aanzien van de onderzochte opleidingen?164 In de eerste plaats kan worden geconcludeerd dat het van belang is (aankomende) leerlingen te informeren over zowel de kwantitatieve als de kwalitatieve aspecten van het arbeidsmarktperspectief

164. Hierbij wordt opgemerkt dat de voorstellen alleen gebaseerd zijn op de resultaten uit dit onderzoek. Bij het beoordelen van deze voorstellen moet worden bedacht dat hierbij niet expliciet de behoeften en de doelstellingen vanuit zowel het bedrijfsleven, alsmede het onderwijsveld zelf zijn betrokken. 
van de opleidingsrichtingen aan het (Kort) MBO. Informatie door met name docenten, evenals oud-leerlingen, maar ook excursies naar bedrijven blijken effectieve voorlichtingsbronnen te zijn. Van belang is derhalve dat docenten goed op de hoogte blijven van de arbeidsmarktontwikkelingen op hun vakgebied. Vanzelfsprekend zal het verstrekken van arbeidsmarktinformatie wervend werken, wanneer er sprake is van knelpunten op de arbeidsmarkt (i.c. moeilijk vervulbare vacatures). Voor een goede informatie aan de aankomende leerlingen is het van belang dat contact wordt gezocht met de belangrijkste vooropleidingen.

Daarnaast is het van belang dat de opleidingen contact onderhouden met de werkgevers. Enerzijds om de werkgevers te informeren over de inhoud van de opleiding, anderzijds om zich door de werkgevers te laten informeren over de ontwikkelingen in het bedrijfsleven.

Een verlenging van de stage, mits deze inhoudelijk redelijk past bij de gevolgde (Kort) MBO-opleiding en voldoende instructie bevat, is daarentegen voor de (Kort) MBO-leerlingen een belangrijke informatiebron over de beroepspraktijk in het algemeen en de in de toekomst te verwachte werkzaamheden. Men dient zich echter wel te realiseren, dat, ondanks een ruimere werkervaring, de kans op een baan via de stageplaats bij een toename van de stageduur niet groter wordt.

Uit zowel de beoordeling van de theoretisch-technische kennis en de praktijkvaardigheden, als uit de geschetste behoefte aan extra kennis en vaardigheden, blijkt, dat het vak computerkunde (en daarmee samenhangende vakken zoals informatica en electronica) momenteel in de opleiding nog niet goed uit de verf komen. Er moet niet alleen meer tijd aan dit vak worden besteed, maar het vak dient ook beter aan te sluiten bij de actuele ontwikkelingen in het bedrijfsleven. Dit geldt met name voor het opdoen van ervaring met de in het bedrijfsleven gebruikte software.

Aan het KMBO zou men bij het vak Nederlands meer aandacht moeten schenken aan de schriftelijke vaardigheden van de leerlingen. Daarentegen kan bij de MBO-opleidingen juist beter meer tijd worden vrijgemaakt voor spreek-en luistervaardigheden. Dit geldt vooral voor de vreemde talen. Het is opvallend dat juist de schoolverlaters van de MTS aan dit laatste zoveel waarde hechten. 
De praktijkonderdelen zouden meer aandacht kunnen krijgen in de MBO-opleiding, waarbij met name de MTS kans zou moeten zien de gebruikte apparatuur en machines, evenals het materiaal en het gereedschap, alsmede de reeds genoemde software te moderniseren. MMO-ers en MEAO-ers zouden tijdens hun opleiding reeds vertrouwd kunnen worden gemaakt met geavanceerde kopieermachines, faxen, kassa's en actuele software-programma's.

Het bijbrengen van relevante sociale vaardigheden, bijvoorbeeld in vakken als praktische beroepsvorming of matschappijleer, kan tenslotte zeer zeker een nuttige bijdrage leveren aan de vermindering van de op dit punt gesignaleerde aansluitingsproblemen.

Daarnaast zal de aansluiting van het HAVO naar het $H B O$ in de toekomst efficiënter moeten verlopen. Op dit moment blijken namelijk veel HAVOschoolverlaters via het MBO naar het HBO door te stromen.

Ook is het van belang dat het $\angle B O$ voldoende kwaliteit behoudt, zodat uitvoerend en/of routinematig (productie)werk door LBO-ers naar behoren verricht kan worden. De laatste jaren blijkt de LTS-opleiding weer beter gewaardeerd te worden door de werkgevers, zodat de vraag naar LTS-ers weer aantrekt. De werkgevers zijn daarentegen kennelijk terughoudender met het in dienst nemen van LEAO-ers. Immers, voor eenvoudig economisch-administratief werk worden nu veelal mensen met een MEAO- of MMO-diploma gevraagd.

\subsubsection{Mogel ijkheden voor werkgevers bij het verbeteren van de aansluitting naar de arbeidsmarkt}

Werkgevers zouden een (financiële) bijdrage kunnen leveren aan de modernisering van praktijkonderdelen aan de opleidingen. Bijvoorbeeld door het beschikbaar stellen van apparatuur. Modernisering van de apparatuur voor de praktijkonderdelen is echter niet voldoende. Er blijkt tevens een grote behoefte te bestaan aan her- en omscholing van het onderwijzend personeel, dat immers met die nieuwe apparatuur en technieken moet kunnen omgaan. Het bedrijfsleven kan aan deze behoefte tegemoet komen door intensief contact te houden met de betreffende docenten en het schoolbestuur en daarbij zowel excursies als bijscholingscursussen voor het onderwijsveld te organiseren.

Ook werkgevers kunnen in de informatievoorziening aan (aankomende) leerlingen zowel een directe als een indirecte rol spelen. 
Enerzijds kunnen zij via excursies naar de bedrijven, gastlessen, tentoonstellingen, workshops, (arbeids)markten en open dagen op de scholen, evenals via stages direct informatie verschaffen aan (aankomende) leerlingen over arbeidsmarktontwikkelingen in de betreffende bedrijfstak en de werkzaamheden die in het bedrijf worden verricht.

De behoefte aan extra kennis en vaardigheden is bij aanvang van de functie het grootst en neemt daarna gestadig af. Het is dus belangrijk dat de werkgever de schoolverlater direct bij aanvang in de nieuwe functie opvangt.

De bedrijfscursussen die erop zijn gericht de werknemer wegwijs te maken in het bedrijf en in de functie, zullen zoveel mogelijk moeten aansluiten bij de door de schoolverlater gesignaleerde aansluitingsproblemen. Met andere woorden, er moet ook aandacht worden besteed aan sociale vaardigheden in het algemeen en de bedrijfscultuur in het bijzonder. Dit kan gebeuren door het geven van een cursus, maar hiervoor kunnen ook (oudere) (ex-)werknemers worden ingezet. Bovendien is het van belang dat de werknemer, die gaat werken met een computer, zo snel mogelijk een (basis)cursus kan volgen die betrekking heeft op het door deze werknemer te gebruiken software-pakket. Indien nodig kan deze cursus worden vervolgd door andere software-cursussen.

Werkgevers kunnen, ook aan tijdelijke en in deeltijd werkende schoolverlaters, vaker medewerking verlenen bij het volgen van een cursus. Daarbij kan meer aandacht worden besteed aan het vrij krijgen voor het volgen van een cursus.

Kernwoord bij de opvang dient maatwerk te zijn, aansluitend op zowel de interessen, mogelijkheden, kennis en vaardigheden van schoolverlaters, als de vereiste kennis en vaardigheden in de werksituatie.

De aansluiting zal met name verbeteren, wanneer de schoolverlaters banen aangeboden krijgen, die in overeenstemming zijn met de kennis en vaardigheden die zij tijdens de door hen gevolgde opleidingen hebben opgedaan. Werk kan het beste een uitdaging voor de schoolverlaters zijn, zodat zij hun functie gemotiveerd vervulien.

Het bedrijfsleven kan de knelpuntenproblematiek onder andere aanpakken door de verdringing en de devaluatie van de onderwijsdiploma's tegen te gaan. Werkgevers zullen hun opleidingseisen mogelijk meer moeten gaan afstemmen op 
de werkelijke functie-eisen en minder op het (vermeende) grote aanbod van werknemers. Wanneer men werknemers wil werven voor een loopbaan binnen een bedrijf kan men onder andere een carrière in plaats van een baan proberen aan te bieden, ondersteund door een opleidingsplan.

Uit bovenstaande wordt duidelijk, dat de arbeidsmarktpositie van de schoolverlaters van het (Kort) MBO en de aansluiting van deze opleiding op de arbeidsmarkt niet alleen afhankelijk is van deze opleiding zelf, maar ook van ontwikkelingen rondom andere onderwijssectoren, de situatie op de arbeidsmarkt en de bereidheid van werkgevers in te spelen op de waargenomen aansluitingsproblemen.

\subsection{Besluit}

Hoewel de enquête onder ruim 800 schoolverlaters uit 1987 en 1988 van het (Kort) MBO in Midden-Limburg een ruim inzicht heeft geboden in de arbeidsmarktpositie van deze schoolverlaters en de aansluiting van deze opleiding op hun werksituatie, heeft dit onderzoek, zoals doorgaans het geval is, niet alleen veel vragen beantwoord, maar ook nieuwe vragen opgeroepen.

Zo zou men na moeten gaan of de waargenomen verschillen tussen schooltypen en examenjaren op toevaliige discrepanties en fluctuaties berusten, of dat er sprake is van structurele ontwikkelingen. Dit kan alleen worden vastgesteld, wanneer de schoolverlaters van de onderzochte schooltypen periodiek worden geënquêteerd. Voor een goed begrip van de doorstroming van schoolverlaters op de arbeidsmarkt is het bovendien zinvol de huidige onderzoekspopulatie over enkele jaren opnieuw te benaderen. Men kan dan zien in hoeverre de nu gesignaleerde aansluitingsproblemen zich nog voordoen en nagaan op welke wijzen hierop is ingespeeld door de verscheidene betrokkenen. Anderzijds is een verdergaande statistische analyse van de resultaten nodig om een beter inzicht te krijgen in de achterliggende factoren van de aansluitingsproblematiek op de arbeidsmarkt.

Bovendien is voor een totaal overzicht van de arbeidsmarktpositie van de schoolverlaters en de aansluitingsproblematiek op zijn minst vereist, dat ook de vraagzijde van de arbeidsmarkt in beeld wordt gebracht. Bijvoorbeeld om hierdoor meer te weten te komen over de werkgelegenheidsverwachtingen van de werkgevers en hun mening ten aanzien van de inzetbaarheid van bepaalde groepen schoolverlaters. 
$-108-$

Daarnaast kan men overwegen om enkele relevante overheidsinstanties te benaderen, alsmede schooldecanen, (aankomende) leerlingen en hun ouders. De eerste groep kan meer inzicht verschaffen in de toekomstige beleidsvoornemens op het terrein van onderwijs- en arbeid. De tweede groep kan informatie geven over de factoren die van belang zijn bij de school-en beroepskeuze en de daarmee samenhangende verwachtingen, die (aankomende) leerlingen koesteren ten aanzien van hun toekomstige werksituatie.

De beschikbaarheid van bovengenoemde gegevens zou voor het COA, als intermediair tussen scholen, leerlingen en werkgevers, een ondersteuning betekenen voor zijn activiteiten, gericht op het verminderen van de aansluitingsproblemen tussen opleidingen en de beroepspraktijk. 


\section{LITERATUUR}

COA Limburg (1988), Vernieuwing in het $M B O$, paper n.a.v. gelijknamig symposium, Contactcentrum Onderwijs Arbeid (COA) Limburg, Maastricht

ETIL (1984), Instroom van schoolverlaters op de arbeidsmarkt, Economisch Technologisch Instituut Limburg (ETIL), Maastricht

Galan, C. de, A.J.M. van Miltenburg (1985), Economie van de arbeid, Serie Maatschappijbeelden, Samsom uitgeverij, Alphen aan den Rijn

Grip, A. de (1987), Onderwijs en Arbeidsmarkt: Scholingsdiscrepanties, VUuitgeverij, Amsterdam

Grip, A. de (1988), Scholing en Werk, SMO-boek, Stichting Maatschappij en Onderneming, Den Haag

Hoof, J.J. van, J. Dronkers (1980), Onderwijs en arbeidsmarkt, Sociologische monografieën, Van Loghum Slaterus, Deventer

OSA (1988), Arbeidsmarktperspectieven; OSA-rapport 1988, OSA-publicatie R5, Organisatie voor Strategisch Arbeidsmarktonderzoek (OSA), Den Haag

Paridon, W.C.G.M. van (1987), De arbeidsmarktindicator, in: Management Berichten, jr. 13, nr. 3, p. 42-46, PTT, Den Haag

Reiche, H.M.J.K.I., J.J. Riphagen (1988), Beroepsonderwijs in de markt, COB/SER-publicatie 88-71, Commissie Ontwikkeling Bedrijven (COB), Sociaal-Economische Raad (SER), Den Haag

Segers, J.H.G. (1983), Sociologische onderzoeksmethoden, deel 1, Van Gorcum, Assen

SER (1987), Advies informatie werkgelegenheidsstructuur, SER-publicatie 8716, Sociaal-Economische Raad (SER), Den Haag

Sociale Zaken en Werkgelegenheid, Ministerie van, Directoraat-Generaal voor de Arbeidsvoorziening (1988), Schoolverlatersbrief 1988, Ministerie van Sociale Zaken, Rijswijk

Stijnen, F.H.H.C., M.H. Wieling (1988), Arbeidsmarktverwachting en arbeidsmarktpositie van LTS-ers, Researchcentrum voor Onderwijs en Arbeidsmarkt (ROA), Faculteit der Economische Wetenschappen, Maastricht

Velraeds, H., Ch. van Esch (1988), Schoolverlatersenquête 1987, Contactcentrum Onderwijs Arbeid (COA) Westelijke Mijnstreek, Sittard

Vissers, A.M.C. (1979), Mobiliteit op de arbeidsmarkt, een literatuurstudie over arbeidsmobiliteit en over segmentering van de arbeidsmarkt, Instituut voor sociaal-wetenschappelijk onderzoek (IVA), Katholieke Hogeschool, Tilburg 



\section{OVERZICHT TABELLEN}

TABEL NR: $\quad$ BLZ: TITEL:

Tabe1 1.1. 3 Achtergronden van moeilijk vervulbare vacatures, in procenten

Tabe1 1.2. 4 Arbeidsmarktindicator schoolverlaters naar opleidingsniveau en -richting

Tabel 1.3. 8 Onderzoekspopulatie naar opleidingsrichting en schooltype, in procenten

Tabe1 2.1. 22 Vooropleiding, per schooltype, in procenten

Tabe1 2.2. 23 Geboortejaar, per schooltype, in procenten

Tabel 2.3. 24 Opleiding moeder van schoolverlater, per schooltype, in procenten

Tabel 2.4. 24 Opleiding vader van schoolverlater, per schooltype, in procenten

Tabel 2.5. 26 Motieven voor de keuze van de opleidingsrichting, per schooltype, in procenten

Tabel 2.6. 29 Belang van voorlichtingsbronnen over de arbeidsmarkt, per schooltype, in procenten

Tabe1 3.1. $\quad 34$ Activiteiten op verscheidene peildata, per examenjaar, in procenten

Tabel 3.2. 35 Actitviteiten nadat (Kort) MBO-opleiding een half jaar is verlaten, per schooltype, gedifferentieerd naar examenjaar, in procenten

Tabe1 3.3. 39 Vervolgopleidingen, per schooltype, in procenten

Tabel 3.4. 40 Motieven voor volgen van vervolgopleidingen, per schooltype, in procenten

Tabel 3.5. 43 Verwachte economische bezigheid na dienstplicht, per schooltype, in procenten

Tabe1 3.6. 44 Wijze waarop huidige functie is verkregen, per schooltype, in procenten

Tabel 3.7. 45 Soort aanstelling, per schooltype, in procenten

Tabe1 3.8. 47 Arbeidsduur per week, per schooltype, in procenten

Tabe1 3.9. 50 Beroepen van MEAO-ers en MMO-ers, in procenten

Tabe1 3.10. 52 Beroepen van MTS-ers en KMBO-ers, in procenten

Tabe1 3.11. 55 Bedrijfssectoren, waarin MEAO-ers en MMO-ers werkzaam zijn, in procenten 
Tabe1 3.12. 56 Bedrijfssectoren, waarin MTS-ers en KMBO-ers werkzaam zijn, in procenten

Tabel 3.13. 57 Personeelsomvang van de bedrijven, waar de schoolverlaters werkzaam zijn, per schooltype, in procenten

Tabe1 3.14. 58 Regio, waarin schoolverlaters werkzaam zijn, per schooltype, in procenten

Tabel 3.15. 61 Regio, tot waar werkende schoolverlater een functie wil aanvaarden, per schooltype, in procenten

Tabe1 3.16. 62 Netto inkomen per maand in guldens, per schooltype, in procenten

Tabe1 3.17. 65 Functie-aspecten, per schooltype, in procenten

Tabe1 4.1. 69 Beoordeling theoretisch-technische vakken aan het MEAO, in procenten

Tabe1 4.2. 71 Beoordeling theoretisch-technische vakken aan het MMO, in procenten

Tabe1 4.3. 72 Beoordeling theoretisch-technische vakken aan het MTS, in procenten

Tabe1 4.4. 74 Beoordeling theoretisch-technische vakken aan het KMBO, in procenten

Tabe1 4.5. 78 Percentage schoolverlaters dat vindt dat de genoemde praktijkonderdelen voldoende geoefend zijn, per schooltype

Tabel 4.6. 79 Percentage schoolverlaters dat vindt dat de genoemde praktijkonderdelen verouderd zijn, per schooltype

Tabe1 4.7. 80 Percentage schoolverlaters dat genoemde praktijkonderdelen vaak nodig heeft in de beroepspraktijk, per schooltype

Tabel 4.8. 85 Extra kennis en vaardigheden waaraan schoolverlaters behoefte hebben in de dagelijkse beroepspraktijk, per schooltype, in procenten

Tabel 4.9. 87 Motieven voor het volgen van een aanvullende cursus, per schooltype, in procenten

Tabe1 4.10. 88 Medewerking van werkgever bij het het volgen van een aanvullende cursus, per schooltype, in procenten

Tabe1 4.11. 90 Begeleiding door werkgever bij het inwerken in huidige functie, per schooltype, in procenten

Tabe1 5.1. 94 Actitviteiten nadat (Kort) MBO-opleiding een half jaar is verlaten, per schooltype, gedifferentieerd naar examenjaar, in procenten 
OVERZICHT VAN FIGUREN

FIGUUR NR: $\quad$ BLZ: $\quad$ TITEL:

Figuur 1.I. $\quad 10 \quad$ Conceptueel model van de invloed van aanbodfactoren op de arbeidsmarktpositie en de aansluiting tussen opleiding en werk van de schoolverlaters

Figuur 1.II. 16 Respons, per schooltype, gedifferentieerd naar examenjaar, in procenten

Figuur 2.I. 21

Percentage vrouwen, per schooltype

Figuur 2.II. $\quad 28$

Percentage schoolverlaters bij wie de kans op werk van invloed is geweest op de keuze van de opleidingsrichting, per schooltype

Figuur 3.I. $\quad 60$

Percentage in Midden-Limburg werkende schoolverlaters, dat bereid is buiten Midden-Limburg te werken, per schooltype

Figuur 4.I. $\quad 67$

Percentage werkende schoolverlaters dat de huidige functie vindt aansluiten bij hun opleiding, per schooltype

Figuur 4.II. $\quad 75 \quad$ Percentage werkende schoolverlaters dat gemiddeld de aandacht en de actualiteit als voldoende beoordeelt en de vakken regelmatig in de huidige functie gebruikt, per schooltype

Figuur 4.III.a. 76 Percentage werkende schoolverlaters dat gemiddeld de aandacht voor mondelinge taalvaardigheid als voldoende beoordeelt, per schooltype

Figuur 4.III.b. 77

Percentage werkende schoolverlaters dat gemiddeld de aandacht voor schriftelijke taalvaardigheid als voldoende beoordeelt, per schooltype

Figuur 4.III.C. 77

Percentage werkende schoolverlaters dat gemiddeld een bepaalde taal nodig heeft in huidige functie, per schooltype

Figuur 4.IV. $\quad 80 \quad$ Mening van werkende schoolverlaters over stageduur, per schooltype in procenten

Figuur 4.V. $82 \quad$ Percentage werkende schoolverlaters waaraan stagebiedend bedrijf een betaalde baan heeft aangeboden, per schooltype

Figuur 4.VI. 83 Percentage werkende schoolverlaters, dat in de huidige functie behoefte heeft aan kennis die niet tijdens hun opleiding aan bod is gekomen, per schooltype

Figuur 4.VII. 84 Percentage werkende schoolverlaters, dat in de huidige functie behoefte heeft aan vaardigheden die niet tijdens de opleiding aan bod zijn gekomen, per schooltype 
$\ldots$ 
SAMENSTELLING VAN DE BEGELEIDINGSCOMMISSIE VOOR HET SCHOOLVERLATERSONDERZOEK VAN HET (KORT) MBO IN MIDDEN-LIMBURG

De heer drs. A.J.M.L. Kaumo; voorzitter secretaris van de Kamer van Koophandel en Fabrieken voor Midden-Limburg, Roermond

De heer ing. A.J.T. Hones

directeur van de Middelbare Technische School, Roermond

De heer F.M.G. Canton

directeur van het Middelbaar Economisch en Administratief Onderwijs en het Middelbaar Middenstands Onderwijs, Scholengemeenschap voor Economisch en Administratief Onderwijs, Roermond

De heer M.F.H.G.M. Pijpers

waarnemend directeur van de onderwijsgemeenschap voor het Kort Middelbaar Beroepsonderwijs, Stichting Vorming en Onderwijs, Roermond

De heer drs. A.M. Kleijnen medewerker stafbureau en coördinator afdelingen administratie Brood \& Banket en Procestechniek van de onderwijsgemeenschap voor het Kort Middelbaar Beroepsonderwijs, Stichting Vorming en Onderwijs, Roermond

Mevrouw M.L.H. Depondt - 01 ivers

directeur van het Contactcentrum Onderwijs Arbeid Limburg, Maastricht

Mevrouw J. Notenboom regionaal coördinator van het Contactcentrum Onderwijs Arbeid MiddenLimburg, Roermond 

$-114-$

Bijlage 2

VRAGENLIJST EN BEGELEIDENDE BRIEVEN

Versie: MTS-1988165

165. Voor de andere versies, zie bijlagenboek. 
Roermond, 23 januari 1989

Beste oud-leerling,

Het is al weer ruim een half jaar geleden, dat je op onze MTS je diploma gehaald hebt. Wij zijn dan ook geinteresseerd in de ervaringen, die je daarna hebt opgedaan. Bijvoorbeeld of je na onze opleiding gemakkelijk een baan hebt kunnen vinden of dat je naar een vervolgopleiding bent gegaan. Om dit alles aan de weet te komen, willen wij je vragen aan deze enquete mee te werken.

Wanneer $j i j$ de vragenlijst invult, draag je er toe bij dat we onze MTS beter kunnen afstemmen op de vervolgopleidingen en op de praktijk. Zelf kun je door het beantwoorden van de vragen nog eens overdenken, wat je aan onze MTS gehad hebt. Maar de gegevens zijn ook belangrijk voor jongeren, die nog een schoolkeuze moeten maken. Onze huidige en toekomstige leerlingen kunnen dan zien welke richtingen je met onze MTS-opleiding op kunt.

In Roermond doen enkele scholen voor middelbaar en kort middelbaar beroepsonderwijs mee aan deze schoolverlatersenquete. Deze scholen werken in dit project samen met het Contactcentrum Onderwijs-Arbeid (COA) in MiddenLimburg. Het $\mathrm{COA}$ is een organisatie die activiteiten ontplooit om de aansluiting tussen school en werk beter te laten verlopen. Eén van deze activiteiten is het samen met de scholen op touw zetten van deze enquete. Afgesproken is, dat de scholen de vragenlijsten versturen en het COA de gegevens tot een rapport laat verwerken.

De vragenlijst bestaat uit twee soorten vragen. Ten eerste uit vragen die voor iedereen bedoeld zijn. Ten tweede uit vragen, die passen bij je huidige situatie. Je hoeft dus niet alle vragen in te vullen?

De ingevulde vragenlijst kun je zonder postzegel in de antwoord-enveloppe opsturen naar het COA. Wij krijgen niet te zien welke antwoorden je hebt gegeven, want de formulieren komen niet meer op school terug. Je blijft dus "anoniem"; niemand weet wat $j i j$ hebt ingevuld. Het COA gebruikt de antwoorden alleen voor algemene gegevens.

Tegen de zomervakantie zal over de resultaten van deze enquete verslag uitgebracht worden. Wanneer je een samenvatting van deze resultaten wilt ontvangen, kun je dat op het enquêteformulier aangeven.

Mocht je vragen hebben over het invullen van de vragenlijst, dan kun je contact opnemen met Mw. J. Notenboom van het COA. Haar telefoonnummer staat bij de invulinstructies op het vragenformulier. Lees eerst de invulinstructies. Beantwoord daarna pas de vragen!

We hopen, dat je mee wilt werken en de vragenlijst wilt invullen en opsturen. Alvast hartelijke dank en veel succes in de toekomst.

Met vriendelijke groeten, 
Roermond, 20 februari 1989

Beste oud-leerling,

Zoals je je misschien nog kunt herinnneren, heb jij zo'n drie weken geleden een brief van onze school ontvangen. In die brief hebben wij je gevraagd aan een schoolverlatersenquête mee te werken. Daarin stond ook dat enkele scholen uit de regio Roermond, waaronder onze MTS, samen met het Contactcentrum Onderwijs Arbeid (COA) MiddenLimburg deze enquête op touw hebben gezet.

Tot nu toe echter heeft het COA Midden-Limburg de door jouw ingevulde vragenlijst nog niet (in haar geheel) ontvangen. Daarom willen wij jou nogmaals verzoeken de bijgesloten vragenlijst in te vullen en op te sturen.

$\mathrm{Nu}$ het al weer ruim een half jaar geleden is, dat je onze MTS verlaten hebt, zijn wij geinteresseerd in de ervaringen, die je daarna hebt opgedaan. Bijvoorbeeld of je na onze opleiding gemakkelijk een baan hebt kunnen vinden of dat je naar een vervolgopleiding bent gegaan.

Wanneer jij de vragenlijst invult, draag je er toe bij dat we onze MTS-opleiding beter kunnen afstemmen op de praktijk. Zelf kun je door het beantwoorden van de vragen nog eens overdenken, wat je aan onze MTS gehad hebt. Maar de gegevens zijn ook belangrijk voor jongeren, die nog een schoolkeuze moeten maken. Onze huidige en toekomstige leerlingen kunnen dan zien welke richtingen je met onze MTS-opleiding op kunt. Het $\mathrm{COA}$ kan de resultaten van deze enquête gebruiken bij haar activiteiten voor een betere aansluiting tussen school en werk.

De vragenlijst bestaat uit twee soorten vragen. Ten eerste uit vragen die voor iedereen bedoeld zijn. Ten tweede uit vragen, die passen bij je huidige situatie. Je hoeft dus niet alle vragen in te vullen!

De ingevulde vragenlijst kun je zonder postzegel in de antwoordenveloppe opsturen naar het COA. Wij krijgen niet te zien welke antwoorden je hebt gegeven, want de formulieren komen niet meer op school terug. Het COA werkt alleen met nummers, zoals je achterop de vragenlijst kunt zien. Je blijft dus "anoniem".

Tegen de zomervakantie zal over de resultaten van deze enquete verslag uitgebracht worden. Wanneer je een samenvatting van deze resultaten wilt ontvangen, kun je dat op het enquêteformulier aangeven. 
Mocht je vragen hebben over het invullen van de vragenlijst, dan kun je contact opnemen met Mw. J. Notenboom van het COA. Haar telefoonnummer staat bij de invulinstructies op het vragenformulier. Lees eerst deze invulinstructies. Beantwoord daarna pas de vragen!

We hopen, dat je alsnog mee wilt werken en de vragenlijst wilt invullen en zo snel mogelijk (met kaft en enquêtenummer) opstuurt. In ieder geval voor vrijdag 10 maart a.s. Alvast hartelijke dank en veel succes in de toekomst.

Met vriendelijke groeten,

N.B. Heb jij de ingevulde vragenlijst al wel opgestuurd, maar zonder enquêtenummer, dan ontvang je nu ook opnieuw een vragenformulier. Het COA had namelijk dit enquêtenummer nodig om aan de scholen te kunnen doorgeven van welke nummers het formulier nog niet binnen was. Het is dus belangrijk dat je het ingevulde vragenformulier met enquêtenummer opnieuw naar het COA stuurt. Geef op het vragenformulier, onder het nummer op de kaft, aan dat je de enquête voor de tweede keer opstuurt. Bedankt! 


\section{WAT DOE JE NU?}

Vragenlijst voor schoolverlaters uit $1986 / 87$ en $1987 / 88$

van het MBO en KMBO te Roermond 


\section{INSTRUCTIES VOOR HET INVULLEN VAN DE VRAGEN}

Lees eerst deze toelichting, voordat je de vragen gaat invullen! Dan is het niet moeilijk deze vragenlijst in te vullen.

De vragenlijst bestaat uit twee delen:

- een aantal vragen, die voor iedereen bestemd zijn.

- een aantal vragen, die passen bij je bezigheden op dit moment. Je hoeft dus niet alle vragen in te vullen!

Iedereen begint de vragenlijst bij vraag 1.

Wanneer in de enquête wordt gesproken over richting, ga je uit van de door jou gevolgde richting aan de MTS. Bijvoorbeeld Bouwkunde, Electronica, Electrotechniek (Energietechniek), Procestechniek, Weg- en waterbouwkunde of Werktuigbouwkunde.

Lees telkens eerst de vraag en antwoordmogelijkheden.

Kies daarna jouw antwoord en kruis dit aan of vul de stippeliijn in.

Bij de meeste vragen moet je 1 antwoord aankruisen.

$\mathrm{Bij}$ andere vragen moet je jouw antwoord invulien op een stippelijijn.

Sommige vragen hebben een korte toelichting. Het is nodig, dat je die toelichting leest, voordat je een antwoord invult of aankruist!

Nadat je alle vragen beantwoord hebt, kun je de vragenlijst in de antwoord-enveloppe zonder postzegel versturen naar het COA.

Liefst zo snel mogelijk!

Wanneer de MTS deze vragenlijst naar een verkeerd adres heeft gestuurd (en iemand anders de vragenlijst naar jou heeft doorgestuurd), kun je hieronder het juiste adres invullen? Je blijft dan nog steeds anoniem. Het COA geeft aan de school alleen het gewijzigde adres door!

nieuw adres:

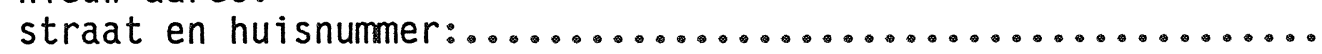

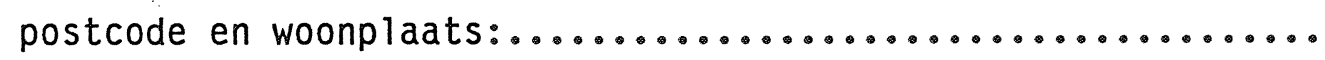

Wanneer je een samenvatting van de enquêteresultaten wilt ontvangen kun je dat op het vragenformulier aangeven. Ook is er ruimte op het formulier voor opmerkingen over deze enquête.

Voor vragen over het beantwoorden van de enquêtevragen, kun je contact opnemen met:

Contactcentrum Onderwijs-Arbeid (COA) Midden-Limburg

Mevr. J. Notenboom

Tel: $04750-17733$ 
Deze vragen moet iedereen beantwoorden!

\section{ALGEMEEN}

1. In deze vraag willen we graag weten waarom $\mathrm{jij}$ jouw richting aan de MTS hebt gekozen.

Kruis de 2 belangrijkste redenen oan:

0 ik wilde graag in deze richting aan het werk

0 de grote kansen op werk

- de vakken bij deze richting spraken mij wel aan

o vrienden kozen ook deze MTS-richting

o de vakken pasten goed bij het vakkenpakket van de voorgaande opleiding

o het vooruitzicht op een hoog inkomen

o op advies van familie, kennissen of vrienden

o op advies van de school, voor ik naar de MTS ging

0 op advies van het arbeidsburo, of een andere instantie

o een andere reden, $n .1 \ldots \ldots \ldots \ldots \ldots \ldots \ldots \ldots \ldots \ldots . . . \ldots$

2. Tijdens je opleiding heb je een vakkenpakket moeten kiezen. Heeft bij jouw keuze van dit vakkenpakket de kans op werk een rol gespeeld?

0 nee

0 ja > Heeft voorlichting aan de MTS invloed gehad op deze keuze?

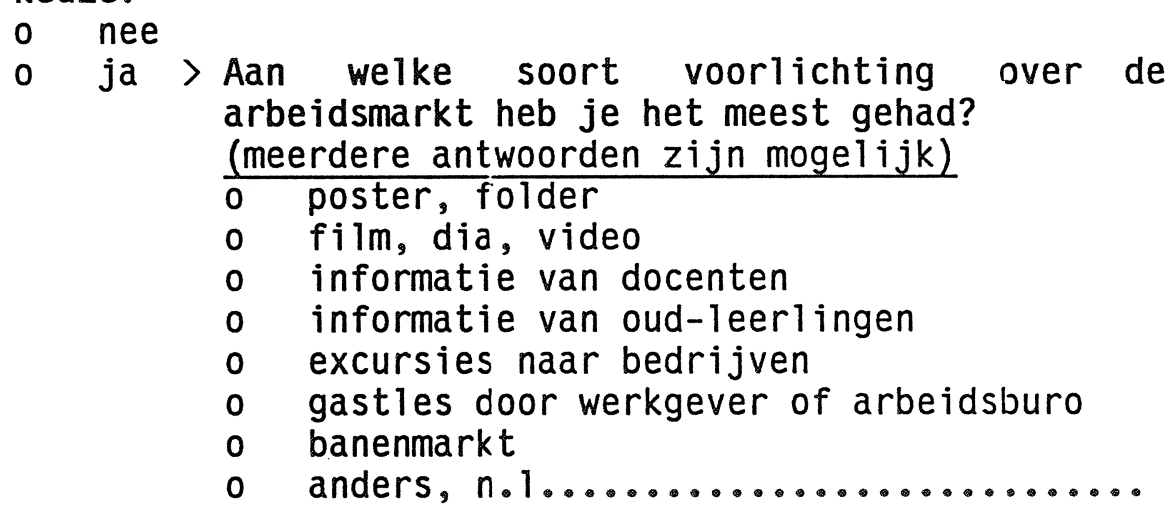

3. Welke opleidingen hebben jouw ouders gevolgd?

Kruis uit onderstaande lijst de hoogste aan:

Lager Onderwijs of gedeelte daarvan

MULO, ULO, MAVO

Lager Beroepsonderwijs (bijv. LTS, LEAO)

MMS, HBS, gymnasium, lyceum, HAVO, VWO

Middelbaar Beroepsonderwijs (bijv. MTS, MEAO)

Hoger Beroepsonderwijs (bijv. HTS, HEAO)

Universitair Onderwijs

Anders, n. 1

\begin{tabular}{cc} 
MOEDER & VADER \\
\hline 0 & 0 \\
0 & 0 \\
0 & 0 \\
0 & 0 \\
0 & 0 \\
0 & 0 \\
0 & 0 \\
0 & 0
\end{tabular}

4. Heeft jouw moeder en/of jouw vader een beroep of opleiding in de richting die jij aan de MTS gekozen hebt? Bijvoorbeeld: je vader is bouwopzichter of je moeder heeft bouwkunde aan de MTS gevolgd.

0 nee

$0 \quad$ ja $>$ Welke ouder(s)?

o moeder

o vader

- moeder en vader 
5. In deze vraag willen we graag achterhalen waarmee je bezig bent geweest na je opleiding aan de MTS.

Hieronder staat een soort kalender waarop je voor iedere maand kunt aangeven wat je dagelijkse bezigheden waren in de periode mei 1988 tot en met december 1988.

Kruis voor elke maand aan wat je toen deed. Als je in een bepaalde maand meerdere bezigheden had, kruis je alleen de bezigheid aan waarmee $j e$ in die maand het meeste bezig was.

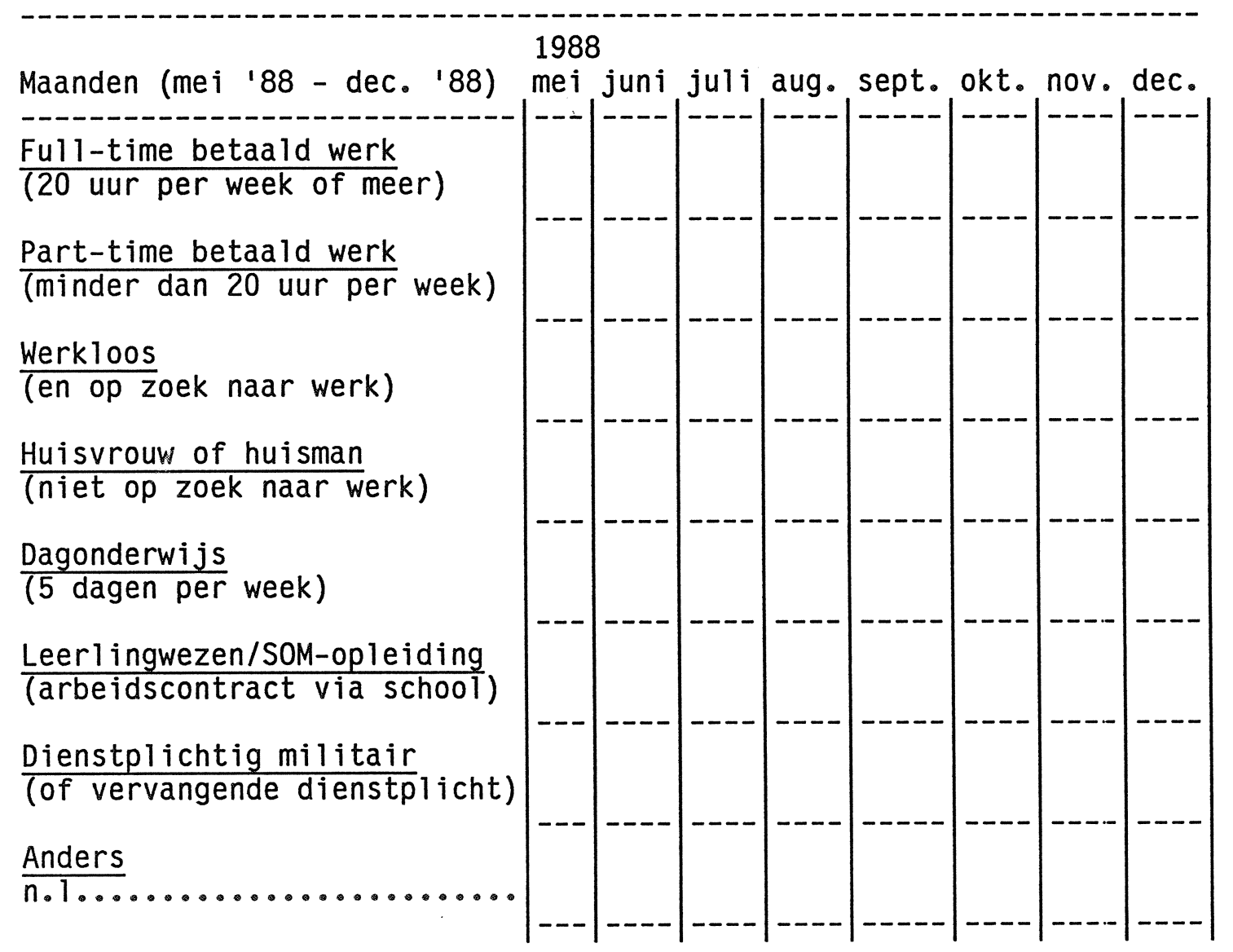

6. Deze vraag gaat over je huidige situatie.

Wat is op dit moment je voornaamste bezigheid?

o Full-time betaald werk

GA VERDER MET BLADZIJJDE 8

o Part-time betaald werk

GA VERDER MET BLADZIJDE 8

o Werkloos en op zoek naar werk

GA VERDER MET BLADZIJDE 4

Huisvrouw/huisman

GA VERDER MET BLADZIJDE 4

Dagonderwijs

GA VERDER MET BLADZIJDE 6

GA VERDER MET BLADZIJDE 8

o Dienstplicht, militair/vervangend

GA VERDER MET BLADZIJDE 7

o Anders, $n .1 \ldots \ldots \ldots \ldots \ldots \ldots . . .$.

GA VERDER MET BLADZIJDE 4 
Alleen mensen uit de groepen "Werkloos en op zoek naar werk", "Huisvrouw of huisman" of "Anders" hoeven deze vragen in te vullen!

II. WERKLOOS, HUISVROUW/HUISMAN EN ANDERS

1. Ben je bij het arbeidsburo ingeschreven?

0 ja

o nee

2. Heb je de afgelopen 4 weken actief naar werk gezocht?

0 nee

$0 \quad$ ja $>$ Hoe heb je in de afgelopen 4 weken naar werk gezocht?

(je mag meerdere antwoorden aankruisen)

0 via advertenties

o via familie, vrienden en kennissen

o via het arbeidsburo

- via het uitzendburo

o via vrijwilligerswerk

o zelf gevraagd bij werkgevers

- via docenten van de MTS

- via stagecontacten

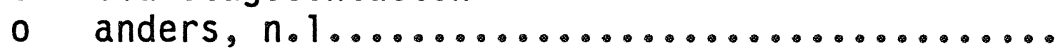

$>$ Hoe vaak heb je in de afgelopen 4 weken gesolliciteerd?

0 geen enkele keer

$0 \quad 1$ of 2 keer

o 3 tot en met 6 keer

07 of meer keer

$>$ Hoe vaak ben $j e$ in de afgelopen 4 weken voor een sollicitatie op gesprek geweest?

0 geen enkele keer

- 1 tot en met 3 keer

04 of meer keer

$>$ Voor hoeveel uur per week zoek je betaald werk?

- minder dan 20 uur per week

020 of meer uur per week

3. Als je nu een geschikte baan zou vinden, kun je dan binnen 2 weken beginnen?

0 ja

$0 \quad$ nee $>$ Kun je niet binnen 2 weken beginnen wegens ziekte?

0 ja

0 nee, andere reden( $\in n)$

4. Ben je werkzaam via een werkervaringsproject?

o ja

5. Ben je bezig een eigen bedrijf op te zetten?

0 nee

$0 \quad$ ja $>$ Heeft men tijdens je opleiding aan de MTS voldoende aandacht besteed aan het opzetten van ' $n$ eigen bedrijf?

0 ja

0 nee 
6. Ben je na je MTS-opleiding bezig (geweest) met een opleiding of cursus?
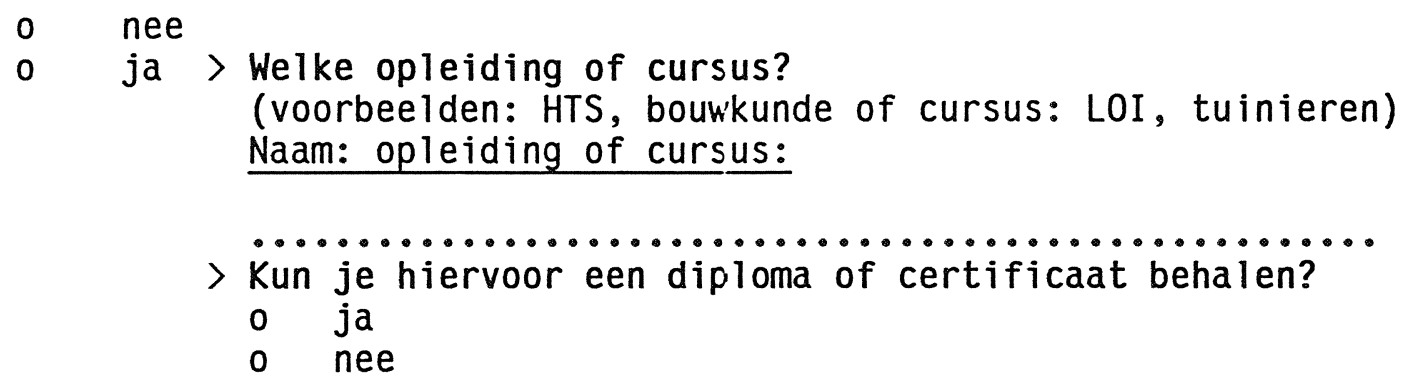

7. Ben je bereid een functie buiten Midden-Limburg (regio Roermond) te aanvaarden?

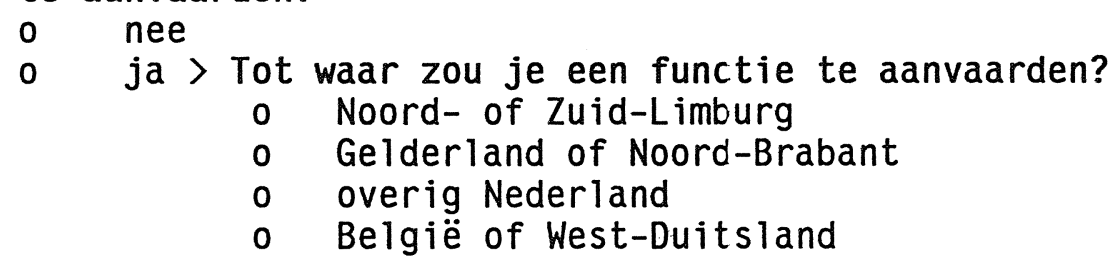

8. Hieronder staan een aantal redenen, waarom je misschien momenteel geen betaald werk kunt vinden. Welke redenen zijn op jouw situatie het meest van toepassing? Kruis maximaal 3 redenen aan:
0 mijn MTS-richting geeft weinig kans op werk
$0 \quad i k$ heb geen goede stagecontacten
o solliciteren vind ik erg moeilijk
o ik ben ouder dan de meeste MTS-ers, dus te duur
0 werkgevers vinden dat ik niet de goede werkhouding heb
$0 \quad i k$ verdien te weinig met het werk dat er wel is
$0 \quad$ alleen in Midden-Limburg zoek ik werk
$0 \quad$ er is te weinig werk voor iedereen die wil werken
0 in het werk, dat ik met mijn MTS-richting kan gaan doen, heb ik geen zin; voor ander werk ben ik niet opgeleid
o wat ik tijdens de MTS heb geleerd, sluit niet aan bij de wensen van werkgevers
o als huisvrouw/huisman heb ik geen tijd om te werken
$0 \quad$ ik heb te weinig werkervaring
o andere reden(en), n.1............................

9. Heb je sinds je van de MTS bent langer dan een half jaar bij 1 werkgever gewerkt?

0 nee GA VERDER MET BLADZIJDE 14

0 ja > Waarom werk je daar niet meer?

0 het arbeidscontract liep af

0 ontslag gekregen

o zelf ontslag genomen

o militaire dienst / vervangende dienstplicht

- gaan studeren in dagonderwijs

- voor gezin gaan zorgen (huisvrouw/huisman geworden)

0 arbeidsongeschikt geworden

0 anders, $n .1$.

GA VERDER MET BLADZIJDE 11 
Alleen mensen die dagonderwijs volgen hoeven deze vragen in te vullen!

\section{DAGONDERWIJS}

1. Welke opleiding volg je nu?

(voorbeeld: HTS)

Welke richting of afdeling volg je binnen deze opleiding?

(voorbeelden: werktuigbouwkunde, bouwkunde)

2. Waarom ben je je huidige opleiding gaan volgen?

Uit onderstaande lijst mag je er maximaal 2 aankruisen.

$0 \quad$ ik kon geen werk vinden, dus ben ik verder gaan leren

$0 \quad i k$ had nog geen zin om te gaan werken

0 het werk, dat ik met mijn MTS-richting kon gaan doen, paste niet voldoende bij mij

o met deze opleiding kan ik straks meer gaan verdienen

o dit opleidingsnivo biedt meer loopbaanmogelijkheden

o de inhoud van de opleiding sprak mij aan

- anderen adviseerden mij deze opleiding te gaan volgen

o vrienden gingen deze opleiding volgen

o dit opleidingsniveau biedt een grotere kans op werk

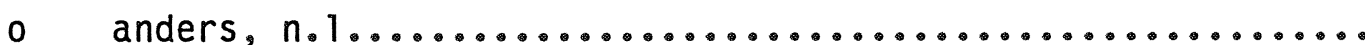

3. Verwacht je deze vervolgopleiding met succes af te ronden?

0 ja

$0 \quad$ nee > Waarom niet?

0 de opleiding is te theoretisch

0 de richting past niet bij mij

$0 \quad$ ik wil toch al eerder gaan werken

o persoonlijke reden(en)

o anders, $n .1 \ldots \ldots \ldots \ldots \ldots \ldots \ldots \ldots$

4. Heb je sinds je van de MTS bent langer dan een half jaar bij 1 werkgever gewerkt?

0 nee GA VERDER MET BLADZIJDE 14

$0 \mathrm{ja}>$ Waarom werk je daar niet meer?

0 het arbeidscontract liep af

0 ontslag gekregen

o zelf ontslag genomen

- militaire dienst / vervangende dienstplicht

- gaan studeren in dagonderwijs

o voor gezin gaan zorgen (huisvrouw/huisman geworden)

0 arbeidsongeschikt geworden

o anders, $n .1 \ldots \ldots \ldots \ldots \ldots \ldots \ldots \ldots \ldots \ldots \ldots . . \ldots$

GA VERDER MET BLADZIJDE 11 
Alleen mensen die hun militaire of vervangende dienstplicht vervullen hoeven deze vragen in te vullen!

\section{DIENSTPLICHT}

1. Ben je na je MTS-opleiding bezig (geweest) met een opleiding of cursus?

Bijvoorbeeld tijdens het vervullen van je dienstplicht?

0 nee

$0 \quad$ ja $>$ Welke opleiding of cursus?

(voorbeelden: HTS-bouwkunde of grootrijbewijs C/D)

Naam opleiding of cursus:

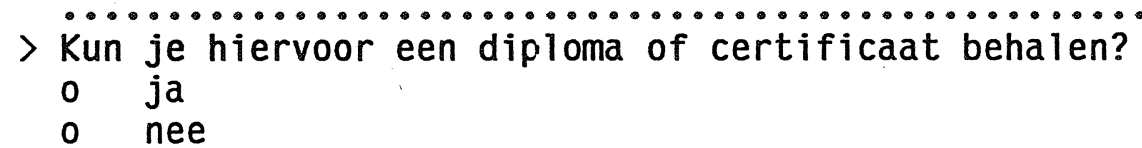

2. Wat wil je na het vervullen van j€ dienstplicht gaan doen?

0 vervolgonderwijs volgen

0 betaald werken in combinatie met deeltijdonderwijs

(bijv. leerlingwezen / SOM-opleiding)

0 betaald werken

o iets anders, $n .1 \ldots \ldots \ldots \ldots \ldots \ldots \ldots \ldots \ldots \ldots \ldots \ldots$

3. Heb je sinds je van de MTS bent langer dan een half jaar bij 1 werkgever gewerkt?

0 nee GA VERDER MET BLADZIJDE 14

o ja > Waarom werk je daar niet meer?

0 het arbeidscontract liep af

o ontslag gekregen

- zelf ontslag genomen

o militaire dienst / vervangende dienstplicht

o gaan studeren in dagonderwijs

- voor gezin gaan zorgen (huisvrouw/huisman geworden)

- arbeidsongeschikt geworden

0 anders, n.1.

GA VERDER MET BLADZIJDE 11 
Alleen mensen die betaald werk verrichten of via het Leerlingwezen een arbeidscontract hebben hoeven deze vragen in te vullen!

v. BETAALD WERK

(Indien je korte tijd geen betaalde arbeid verricht -door bijvoorbeeld ziekte, vakantie of vorstverlet-, beantwoord je de vragen alsof je momenteel werkzaam bent.)

1. Werk je in loondienst?

$0 \quad$ nee > Werk je als zelfstandige (in een eigen bedrijf)?

0 nee, ik werk mee in een gezinsbedrijf; zonder loon

$0 \mathrm{ja}>$ Heeft men tijdens je MTS-opleiding voldoende aandacht besteed aan het opzetten van een eigen bedrijf?

0 ja

0 nee

GA VERDER MET BLADZIJDE 11

o ja > Wat voor aanstelling heb je?

0 vaste aanstelling (incl. proeftijd)

$0 \quad$ tijdelijke aanstelling

o leer-/werkovereenkomst

Alleen mensen in loondienst beantwoorden de volgende vragen!

De overigen GAAN NAAR PAGINA 11 !

2. Bij hoeveel werkgevers heb je na het verlaten van de MTS gewerkt of werk je nog steeds?
o één
0 twee of drie
0 vier of meer

3. Bij hoeveel werkgevers werk je op dit moment?
o één
o meer dan één; de vragen hierna gaan alleen over je belangrijkste werkkring.

4. Op welke wijze ben je aan je huidige werk gekomen?

0 gereageerd op een vacature (in dag- of weekblad)

- via familie of kennissen

0 via docenten of decaan aan MTS-opleiding

0 via stagecontacten of 1 eer-/w'erkovereenkomst

0 via het arbeidsburo

o via tijdelijk werk

o via vrijwilligerswerk

0 op eigen initiatief

o anders, n. $1 \ldots \ldots$......

5. Hoeveel uur werk je per week?

Geef het aantal uren op onderstaande stippellijn aan:

Aantal uur per week:............

6. Werk je in onregelmatige diensten of in ploegendienst?

o ja

0 nee 
De volgende vragen zijn bedoeld om $\epsilon$ en goed beeld te krijgen van het werk dat je nu doet.

7. Hoe heet het beroep of de functie die je nu uitoefent (Voorbeelden: bouwkundig tekenaar of procesoperator) Naam beroep of functie:

8. Wat zijn je voornaamste werkzaamheden?

(Voorbeelden: technisch tekenen of toezicht op bouwplaats)

9. Bij welk bedrijf werk je?

Naam bedrijf:

Plaats bedrijf:

10. Hoeveel is de reistijd tussen je woon- en werkadres? (enkele reis)

$0 \quad$ minder dan 15 minuten

o tussen 15 en 30 minuten

- tussen 30 en 60 minuten

- meer dan 60 minuten

11. Ben je werkzaam buiten Midden-Limburg?

0 ja

0 nee > Ben je bereid een functie buiten Midden-Limburg (regio Roermond) te aanvaarden?

0 nee

- ja > Tot waar zou je een functie te aanvaarden?

0 Noord- of Zuid-Limburg

o Gelderland of Noord-Brabant

0 overig Nederland

o België of West-Duitsland

12. Hoeveel verdien je netto per maand in je huidige functie?

(Je inkomsten uit een uitkering niet meerekenen)

0 minder dan $f 500,--$

0 van $f \quad 500,--$ tot $f 1.000,--$

0 van $f 1.000,--$ tot $f 1.500,--$

$0 \quad \operatorname{van} f 1.500,--$ tot $f 1.750,--$

$0 \quad \operatorname{van} f 1.750,--$ tot $f 2.000,--$

o van $f 2.000,--$ tot $f 2.250,--$

$0 \quad \operatorname{van} f 2.250,--$ tot $f 2.500,--$

0 meer dan $f 2.500,--$

13. Ontvang je naast inkomsten uit betaald werk een uitkering?

o ja

0 nee 
14. In deze vraag gaan we na of je tevreden bent met allerlei eigenschappen van je werk.

a) Ben je tevreden met het aantal uren dat je werkt volgens je arbeidsovereenkomst?
o ja
$0 \quad$ nee > Waarom niet?
o ik zou liever korter werken
o ik zou liever langer werken

b) Moet je wel eens overwerken?

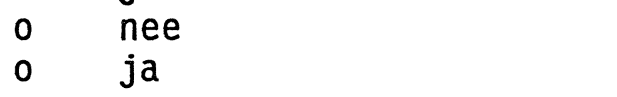

c) Vind je dat werkzaamheden goed aansluiten bij je MTS-opleiding?
0 ja
o nee

15. Hoe ben je bij aanvang in je huidige functie begeleid?

(je mag meerdere antwoorden aankruisen)

o vooraf heb ik een bedrijfstraining / -cursus gevolgd

$0 \quad$ zonder hulp heb ik meteen alle werkzaamheden vervuld

0 ik ben ingewerkt door collega('s)

$0 \quad$ anders, n.

16. Volg je momenteel naast je werk een opleiding of cursus? o nee
ja > Welke opleiding of cursus?
(voorbeelden: Leerlingwezen / SoM-opleiding richting Metaal of LOI, tuinieren of bedrijfscursus management) Naam opleiding of cursus:

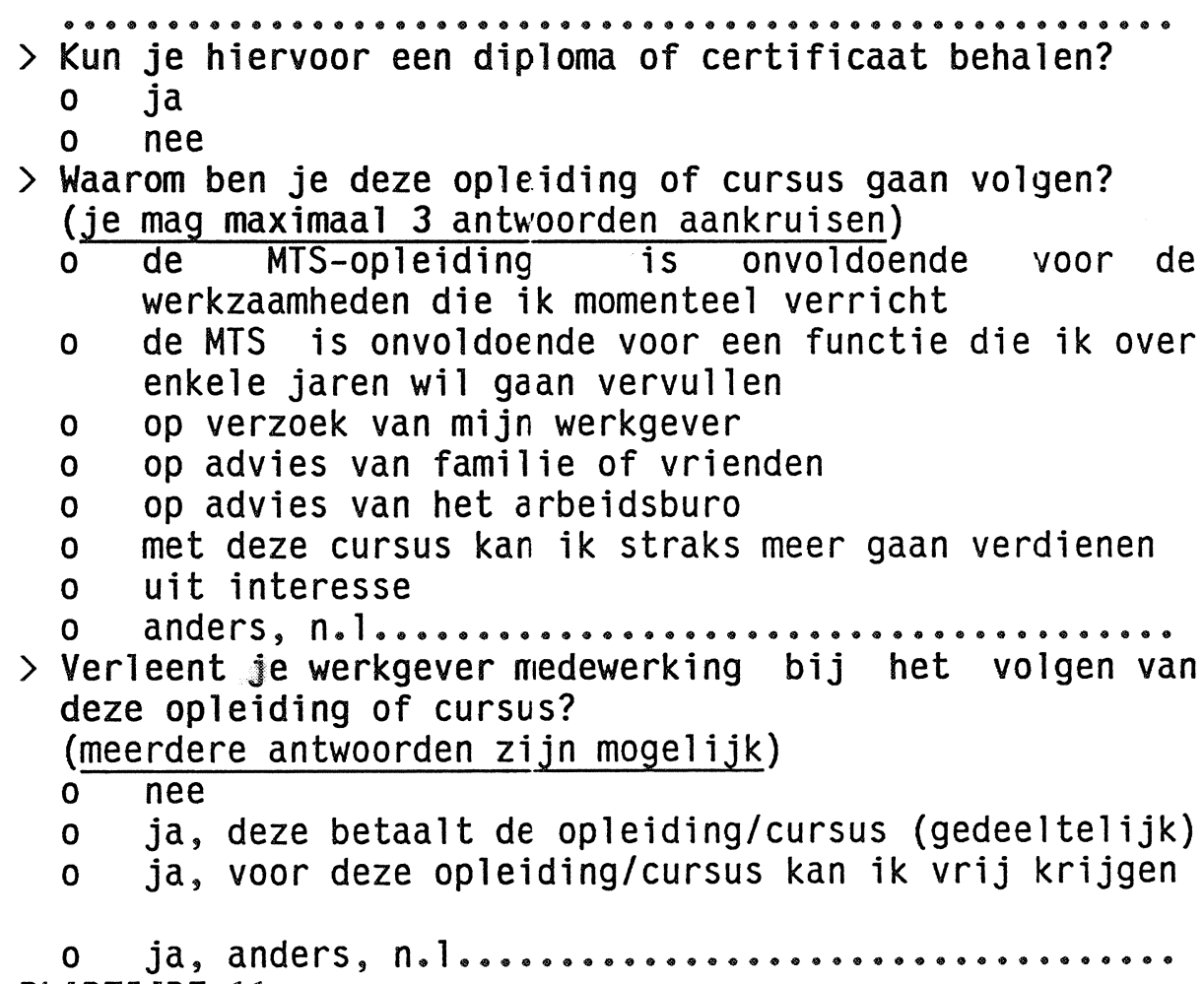


Alleen mensen die momenteel betaald w'erken of die tussen het verlaten van de MTS en nu langer dan een half jaar bij 1 werkgever hebben gewerkt, hoeven deze vragen in te vullen!

\section{AANSLUITING VAN MTS NAAR ARBEIDSMARKT}

In deze vraag willen we graag weten hoe je de aansluiting tussen je opleiding en de beroepspraktijk beoordeelt.

De aansluiting bevat:
1) theoretisch-technische vakkennis
2) taalvaardigheden
3) praktische vaardigheden
4) stage
5) manier van werken

\section{THEORETISCH-TECHNISCHE VAKKENNIS}

In de linker kolom staan vakken die je tijdens de MTS kon volgen. Voor ieder vak moet je het volgende aankruisen:

* GEVOLGD: heb je het vak wel of niet gevolgd tijdens de MTS?
* $\quad \begin{aligned} & \text { AANDACHT: is er tijdens je MTS-opleiding voldoende of } \\ & \text { onvoldoende aandacht geschonken aan dit vak voor het goed }\end{aligned}$
vervullen van je huidige werkzaamheden?
ACTUALITEIT: is de inhoud van het gevolgde vak voldoende of
onvoldoende aangepast aan de dagelijkse beroepspraktijk?
FREQUENTIE: heb je dit vak vaak of weinig nodig bij het
uitoefenen van je huidige werkzaamheden?
wel niet vold.onvold. vold.onvold. vaak weinig

Wis-, Natuur-, Scheikunde o Computerkunde

Technologie

Bedrijfskunde

Bouwk. constructies

Sterkteleer

Bouw- en Landmeten

Weg- en Waterbouwkunde

Elektriciteitsleer Schake1-/Regel techniek Energietechniek

Elektronika

Procestechniek Meet-/Regel techniek Milieutechniek

Werktuigb.constructies Staalconstructies

Transport-/Warmtewerkt. 0 Pneumatiek/Hydrauliek

0

0

0

$0 \quad 0$

$\begin{array}{ll}0 & 0 \\ 0 & 0 \\ 0 & 0 \\ 0 & 0\end{array}$

$\begin{array}{llll}0 & 0 & 0 & 0\end{array}$

$\begin{array}{llll}0 & 0 & 0 & 0\end{array}$

$\begin{array}{llll}0 & 0 & 0 & 0\end{array}$

0

$\begin{array}{llll}0 & 0 & 0 & 0\end{array}$

$\begin{array}{llll}0 & 0 & 0 & 0\end{array}$

$\begin{array}{llll}0 & 0 & 0 & 0\end{array}$

$\begin{array}{llll}0 & 0 & 0 & 0\end{array}$

$\begin{array}{llll}0 & 0 & 0 & 0\end{array}$

0
0

$0 \quad 0$

$\begin{array}{llll}0 & 0 & 0 & 0 \\ 0 & 0 & 0 & 0 \\ 0 & 0 & 0 & 0 \\ 0 & 0 & 0 & 0\end{array}$


Blijk je tijdens je huidige werkzaamheden vaak bepaalde kennis nodig te hebben die tijdens je MTS-opleiding helemaal niet aan bod is gekomen? 0 nee

o ja > Noem deze kennis:

\section{TAALVAARDIGHEID}

In de linker kolom staat de talen die je aan de MTS hebt kunnen volgen. Voor deze vakken moet je het volgende aankruisen:

* GEVOLGD: heb je de taal wel of niet gevolgd tijdens de MTS?

* MONDELING: heeft de MTS voldoende of onvoldoende aandacht besteed aan het goed mondeling kunnen uiten in de beroepspraktijk?

* SCHRIFTELIJK: heeft de MTS voldoende of onvoldoende aandacht besteed aan het goed schriftelijk kunnen uiten in de beroepspraktijk?

* FREQUENTIE: Moet je je vaak of weinig schriftelijk uiten bij het uitoefenen van je beroepspraktijk?

\begin{tabular}{|c|c|c|c|c|}
\hline TAAL & $\begin{array}{l}\text { GEVOLGD } \\
\text { wel niet }\end{array}$ & $\begin{array}{l}\text { MONDELING } \\
\text { vold. onvold. }\end{array}$ & $\begin{array}{l}\text { SCHRIFTELIJK } \\
\text { vold. onvold }\end{array}$ & $\begin{array}{l}\text { FREQUENTIE } \\
\text { vaak weinig }\end{array}$ \\
\hline erlands & 0 & 0 & 0 & 0 \\
\hline els & 0 & 0 & 0 & 0 \\
\hline & 0 & 0 & 0 & 0 \\
\hline
\end{tabular}

\section{PRAKTISCHE VAARDIGHEDEN}

Hierbij gaat het om vaardigheden met:

- apparatuur en machines (bijv. freesbank)

- vakmateriaal en -gereedschap

- software / computerprogrammatuur

Voor iedere soort vaardigheid moet je de volgende aspecten beoordelen:

* PRAKTISCHE OEFENING: werd er voldoende of onvoldoende geoefend met vakgereedschap, vakmateriaal, apparatuur en software?

* ACTUALITEIT: leerde je aan de MTS werken met apparatuur, materiaal, gereedschap en software dat meestal in jouw beroepspraktijk gebruikt wordt? Of was dit aan de MTS verouderd? Of juist te modern?

* FREQUENTIE: maak je vaak of weinig gebruik van deze vaardigheden?

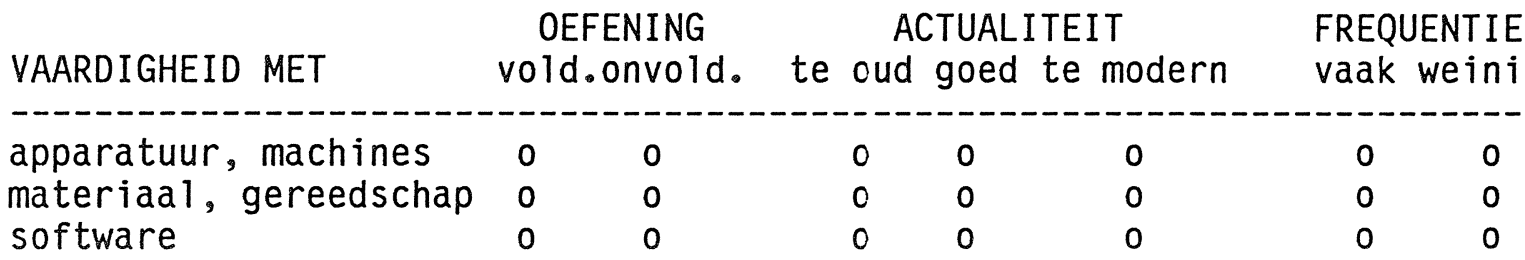


Blijk je in de praktijk vaak vaardigheden nodig te hebben, die tijdens je richting in het geheel niet aan bod zijn gekomen?

0 nee

$0 \mathrm{ja}>$ Noem deze vaardigheden?

4. STAGE

a) Had er meer of minder tijd aan stage(s) besteed moeten worden?

0 minder

0 meer

$0 \quad$ er is precies voldoende tijd aan stage(s) besteed

b) Vond je de werkzaamheden tijdens je stage voldoende aansluiten bij jouw richting aan de MTS ?

0 ja

0 nee

c) Is uit je stagecontacten een betaalde baan voortgekomen?

o ja

0 nee

5. MANIER VAN WERKEN

Hieronder staan enkele kenmerken van je manier van werken genoemd. Welke zijn in jouw functie en bedrijf van belang?

Kruis de 3 belangrijkste aan:

o zelfstandig kunnen werken

o praktisch werken; naar een concreet resultaat streven

o andermans opdrachten stipt uitvoeren; volgzaam zijn

o vlug kunnen aanpassen aan gewijzigde situaties

$0 \quad$ leiding aan een groep mensen kunnen geven

o zelf initiatieven ontplooien; creatief zijn

o jezelf schriftelijk duidelijk en nauwkeurig kunnen uiten

o goed met mensen kunnen omgaan; goed samenwerken met anderen

0 doorzettingsvermogen hebben; tegen veel stress kunnen

$0 \quad$ een goede gezondheid hebben

o jezelf mondeling goed kunnen uiten; mondeling onderhandelen

o risico's durven nemen; hogerop willen

0 technisch inzicht hebben

0 anders, n.1

GA VERDER MET BLADZIJDE 14 
VII. SLOTVRAGEN

1. Wil je graag een samenvatting van de enquêteresultaten ontvangen? 0 ja

0 nee

2. Zou je over enkele jaren bereid zijn aan een vervolgenquête mee te werken? 0 nee

0 ja > Hiervoor is het belangrijk dat we dan weten waar je woont. Daarom een tip: Schrijf het adres van de MTS in je adresboekje of agenda. Wanneer je eventueel gaat verhuizen, kun je ook aan de MTS een adreswijziging sturen.

Het adres van de MTS is:

Middelbare technische School

Kasteel Hillenraedstraat 1

6043 HA Roermond

3. Heb je opmerkingen over deze enquête? Gebruik daarvoor onderstaande ruimte

HIER EINDIGT DEZE ENQUETE.

BEDANKT VOOR HET INVULLEN!

STUUR DE VRAGENLIJST ZO SNEL MOGELIJK OP NAAR HET COA.

GEBRUIK DE ANTWOORD-ENVELOPPE.

EEN POSTZEGEL IS NIET NODIG 
I_I_I I

COA 